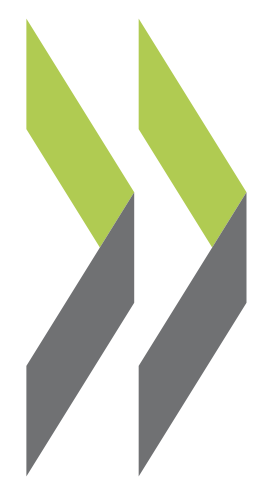

OECD Economics Department Working Papers No. 1016

The Performance of Road Transport Infrastructure and its Links to Policies

\section{Henrik Braconier,}

Mauro Pisu,

Debra Bloch 
Organisation de Coopération et de Développement Économiques

Organisation for Economic Co-operation and Development

28-Jan-2013

ECONOMICS DEPARTMENT

English - Or. English

THE PERFORMANCE OF ROAD TRANSPORT INFRASTRUCTURE AND ITS LINKS TO POLICIES

ECONOMICS DEPARTMENT WORKING PAPERS No. 1016

by Henrik Braconier, Mauro Pisu and Debra Bloch

All Economics Department Working Papers are available through OECD's internet website at www.oecd.org/eco/workingpapers

JT03333648

Complete document available on OLIS in its original format

This document and any map included herein are without prejudice to the status of or sovereignty over any territory, to the delimitation of international frontiers and boundaries and to the name of any territory, city or area. 


\section{ABSTRACT/RÉSUMÉ \\ The performance of road transport infrastructure and its links to policies}

Despite the economic importance of the road transport sector, there is no systematic cross-country evidence on the sector's efficiency. This paper develops a conceptual framework for analysing the social efficiency of the road transport sector, including non-market inputs - such as travel time - and negative outputs - such as accidents and emissions. This framework is then used to analyse efficiency in 32 OECD countries. Data issues in terms of availability, quality and comparability are significant, and the empirical results have to be interpreted with caution. Nevertheless, there is fairly robust evidence that social efficiency is low in a number of OECD countries. The low efficiency suggests that substantial room for input savings exists in these countries. A framework for analysing how road transport policies may impact performance is developed, but a scarcity of data on policy settings currently limits the scope for empirically connecting the two.

JEL classification codes: H41; H54; D61; D62

Keywords: Infrastructure; roads; efficiency; benchmarking; DEA; transport policy

$* * * * * * *$

\section{Infrastructures de transport routier : performance et politiques économiques}

Malgré l'importance économique des transports routiers, les données sur l'efficience du secteur ne font l'objet d'aucune comparaison systématique entre les pays. Dans ce document, il est présenté un cadre conceptuel pour l'analyse de l'efficacité sociale du secteur des transports routiers, englobant des intrants non marchands (comme les temps de trajet) et des extrants négatifs (comme les accidents et les émissions). Il est ensuite recouru à ce cadre pour comparer la situation dans 32 pays de l'OCDE. D'importants problèmes se posent en termes de disponibilité, de qualité et de comparabilité des données et les résultats empiriques doivent être interprétés avec circonspection. Néanmoins, des éléments assez convaincants attestent la faiblesse de l'efficacité sociale dans un certain nombre de pays de l'OCDE, ce qui donne à penser qu'il y existe de grandes possibilités d'économies d'intrants. Il a été entrepris de définir des principes de base à suivre pour analyser les conséquences que les politiques des transports routiers peuvent avoir sur la performance, mais, faute de données suffisantes sur les cadres d'action, il n'est actuellement guère possible d'établir un lien empirique entre les deux analyses.

Classification JEL : H41 ; H54 ; D61 ; D62

Mots clés : Infrastructures ; efficacité ; routes ; comparaison ; analyse DEA ; politique des transports 


\section{TABLE OF CONTENTS}

\section{THE PERFORMANCE OF ROAD TRANSPORT INFRASTRUCTURE AND ITS LINKS}

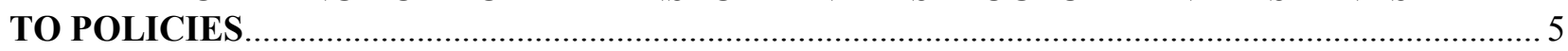

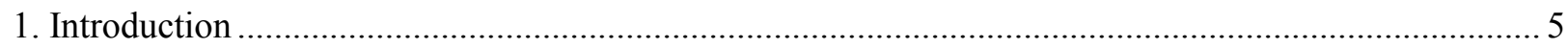

2. A framework for benchmarking road infrastructure and transport performance .................................. 6

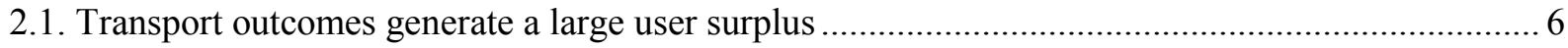

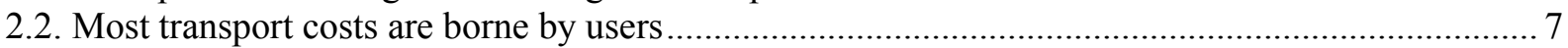

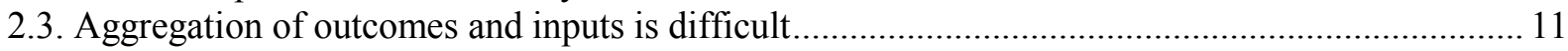

2.4. A framework for analysing efficiency in the road transport sector ............................................. 12

3. Benchmarks for the road transport sector and infrastructure performance ......................................... 13

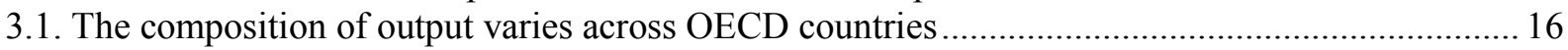

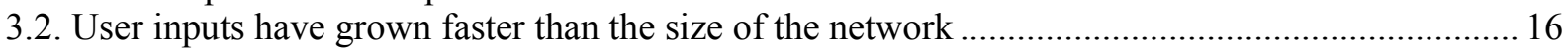

3.3. Different efficiency benchmarks provide different country rankings........................................... 19

4. Estimating the efficiency of the road transport sector and infrastructure ........................................... 21

4.1. The social efficiency of the road transport sector is low in some OECD countries .......................2 21

4.2. The results are robust to alternative model specifications and not driven

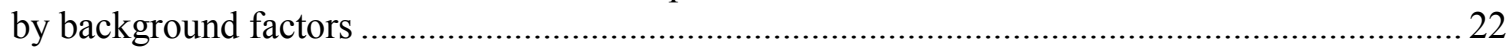

4.3. Some countries show large scope for efficiency gains ................................................................ 25

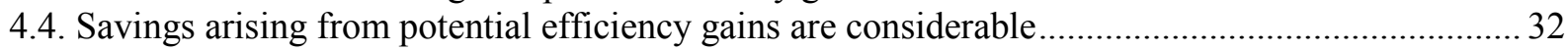

4.5. Input-output elasticities are not precisely estimated ...................................................................... 34

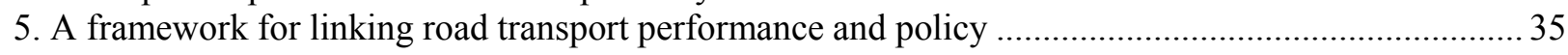

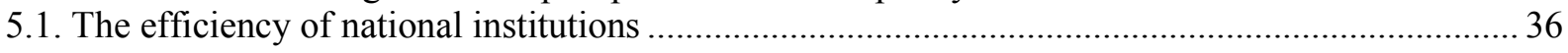

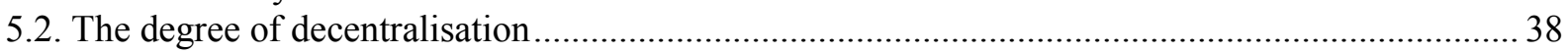

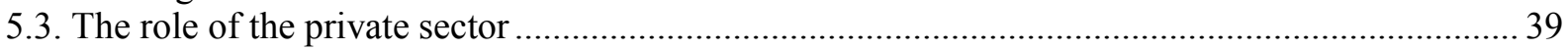

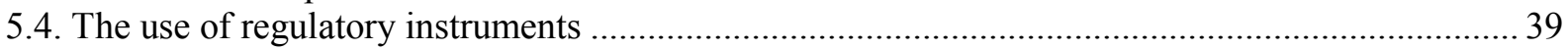

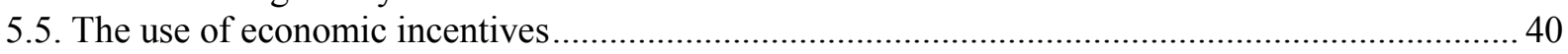

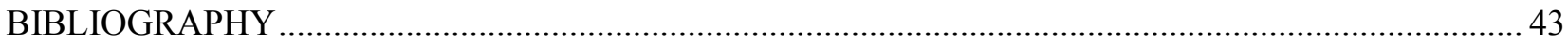

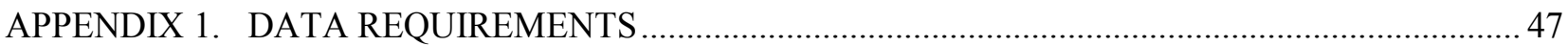

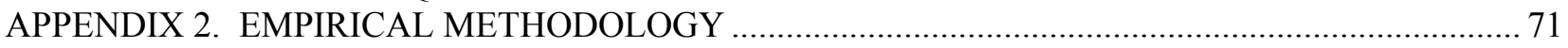

APPENDIX 3. EMPIRICAL ESTIMATES OF ROAD TRANSPORT SECTOR EFFICIENCY ............. 77

\section{Boxes}

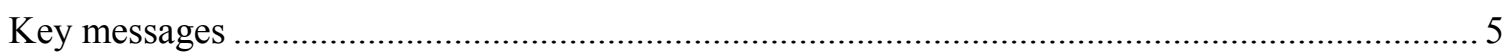

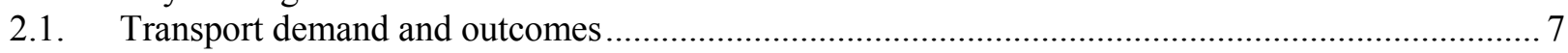

2.2. Estimating congestion and travel time variation between US cities using web-based

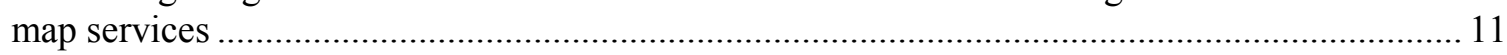

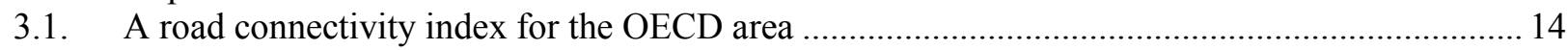

4.1. The effect of geographic factors and other modes of transport is limited .................................. 26

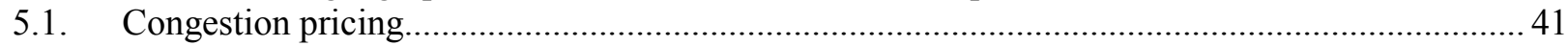

\section{Tables}

2.1. Illustrative marginal costs for passenger cars and goods vehicles ........................................ 8

2.2. Summary statistics of travel time and congestion .................................................................. 11

3.1. Examples of data issues limiting the evaluation of road sector performance............................... 13 


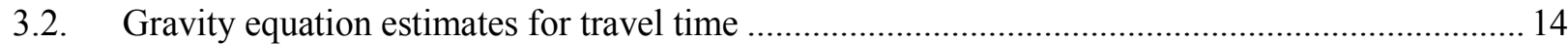

4.1. Potential improvements in separate dimensions are positively correlated .................................. 30

5.1. Examples of policy challenges in designing road transport policies ........................................... 37

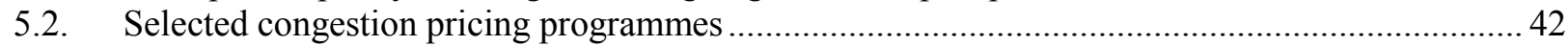

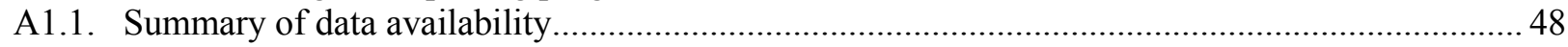

A1.2. Survey parameters for road freight transport data collected by Eurostat .................................. 51

A1.3. Passenger and freight movements in 2005 - a comparison of sources.........................................52

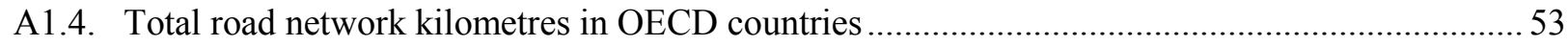

A1.5. Summary of sources and dates for the input and output indicator diamonds ............................... 54

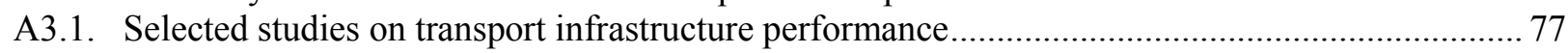

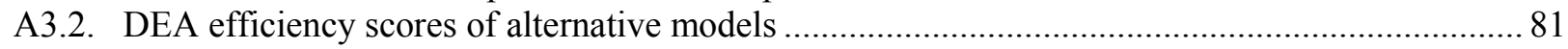

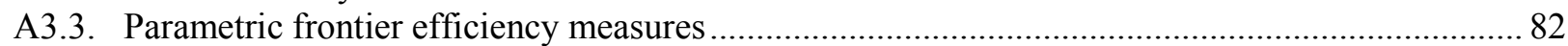

A3.4. DEA and parametric frontier efficiency estimates are positively correlated............................... 83

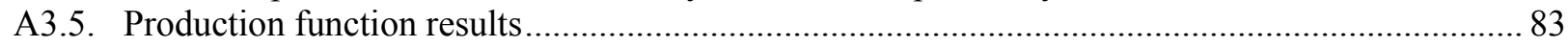

\section{Figures}

2.1. Infrastructure and maintenance spending on roads as a share of GDP ..................................... 9

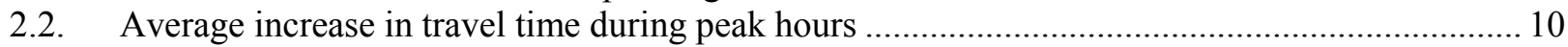

2.3. A framework for analysing road transport infrastructure performance...................................... 12

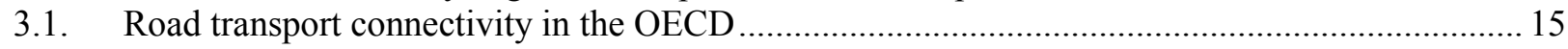

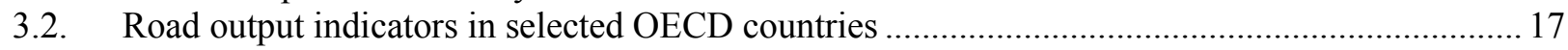

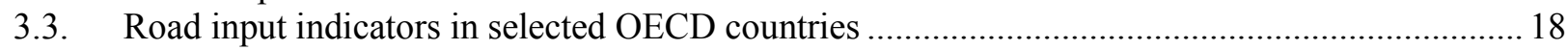

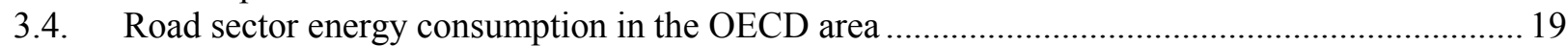

3.5. Benchmark indicators for passenger and freight road transport ........................................... 20

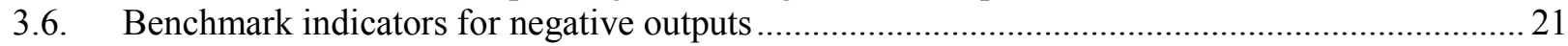

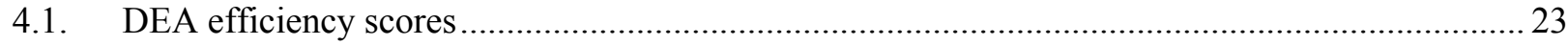

4.2. DEA efficiency scores are broadly unchanged using alternative road network proxies ............... 24

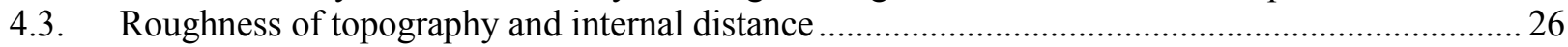

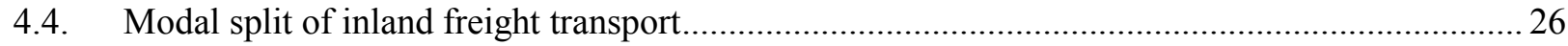

4.5. DEA efficiency scores with respect to specific variables.........................................................2 29

4.6. DEA efficiency scores with respect to the road network and motor vehicles .............................. 31

4.7. Potential savings from reducing investment and maintenance and energy consumption............... 33

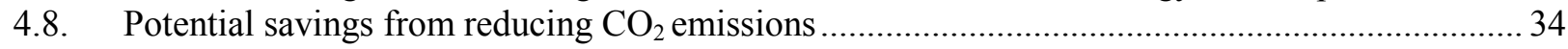

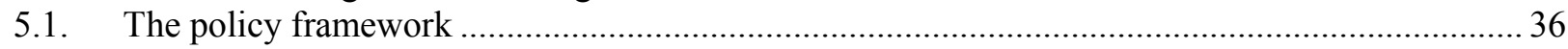

A1.1. Average time spent in car, motorcycle and van travel per day................................................. 56

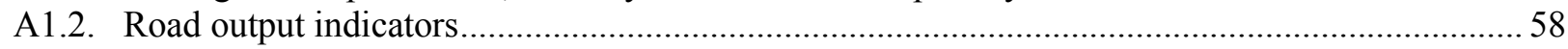

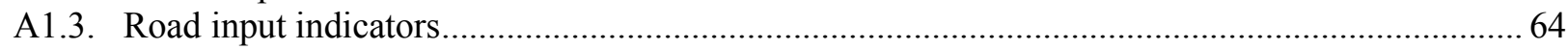

A2.1. The efficiency frontier and the measurement of potential efficiency gains ............................... 72

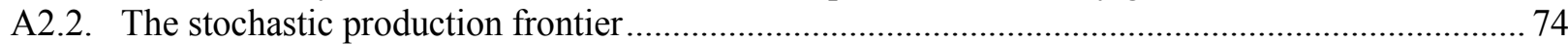

The statistical data for Israel are supplied by and under the responsibility of the relevant Israeli authorities. The use of such data by the OECD is without prejudice to the status of the Golan Heights, East Jerusalem and Israeli settlements in the West Bank under the terms of international law. 


\title{
THE PERFORMANCE OF ROAD TRANSPORT INFRASTRUCTURE AND ITS LINKS TO POLICIES
}

\author{
by
}

Henrik Braconier, Mauro Pisu and Debra Bloch ${ }^{1}$

\section{Key messages}

- Road transport and infrastructure performance should be evaluated taking into account all relevant inputs and outputs. A framework to analyse the social efficiency of the road transport sector is developed, which includes both public and private inputs and positive and negative outcomes.

- Although data coverage of the road sector is better than for many other infrastructure sectors, the availability of internationally comparable data is still limited. This means that efficiency estimates have to be interpreted with caution. Addressing major data shortcomings - in terms of availability, quality and comparability - is key to developing more robust efficiency measures.

- OECD countries display large variations in input and output combinations, highlighting the importance of an integrated approach to estimate efficiency.

- Non-parametric analysis shows that in most OECD countries the road transport sector seems to be relatively close to the efficiency frontier, although these efficiency estimates are often imprecise. However, for a minority of countries there is fairly robust evidence that road transport efficiency can be increased by $5-35 \%$. Parametric methods provide little guidance on road transport efficiency in the OECD area.

- Some of the less well performing countries show scope for improvements in most output and input dimensions. Others show large potential gains in specific areas, such as reducing energy consumption, road infrastructure investment or the length of the road network.

- Describing national policy settings in the road transport sector and analysing their impact on efficiency would require additional data. A framework for linking policies and performance is developed, and data requirements are specified.

\section{Introduction}

The transport sector is key to many aspects of economic life, with road transport playing a dominant role. The road sector provided almost $80 \%$ of inland freight transport within the European Union in 2009 (Eurostat, 2010) and $86 \%, 75 \%$ and $58 \%$ of total passenger kilometres in the United States, Europe and Japan respectively in 2004 (Persson and Song, 2010).

1. The authors are indebted to Kurt van Dender, Jørgen Elmeskov, Peter Hoeller and Jean-Luc Schneider, delegates to the Working Party No. 1 on Macroeconomic and Structural Policy Analysis and colleagues in the OECD Economics Department for useful comments. The authors would like to thank Susan Gascard for excellent editorial support. Mario Barreto and his collegues at the ITF have been extremely helpful in providing data, while Casper Meyer-zu-Schlochtern and Arnaud Atoch provided invaluable programming help to extract road distance and travel-time data. 
The economic costs related to the road transport sector are large. Total road transport costs, including time costs, have been estimated to amount to 20-25\% of GDP (Quinet, 1994; Persson and Song, 2010). Furthermore, passenger transport may grow by $10-50 \%$ and freight traffic by $50-130 \%$ in the OECD between 2010 and 2050 (ITF, 2012). Ensuring efficiency is, therefore, crucial for raising social welfare and potentially lower infrastructure investment needs in the future.

Despite the importance of the road transport sector, there is a lack of cross-country comparisons of outputs, inputs and efficiency. This partly reflects a lack of an analytical and empirical framework, but also significant problems relating to data coverage, quality and comparability. An analytical framework to analyse the social efficiency of the road transport sector is developed in section 2 . The focus is on social efficiency as key inputs and outputs affecting welfare may otherwise be excluded, e.g. in terms of time, congestion and emissions. In this study, a broad set of outputs and inputs are considered to compare social efficiency of the road transport sector across OECD countries. Section 3 discusses data availability, comparability and quality. It also provides indicators of inputs, outputs and efficiency across OECD countries. The fourth section produces more sophisticated benchmarks based on Data Envelopment Analysis (DEA). Section 5 outlines how policy settings may affect the social efficiency of the road transport sector. A more exhaustive analysis of policy issues would require a substantial amount of new and detailed data on road transport policy settings.

\section{A framework for benchmarking road infrastructure and transport performance}

\subsection{Transport outcomes generate a large user surplus}

Firms and households benefit from transport in the form of higher productivity, more competition, enhanced employment opportunities, an expanded choice of housing and consumption possibilities, and better access to recreation and leisure. The net benefits can be thought of as the difference between user's willingness to pay and the costs of producing transport. ${ }^{2}$

In a standard transport model, gross user benefits increase with the number of trips (Box 2.1). The number of trips could thus be a natural transport outcome variable, but such data are only available for a few OECD countries. Instead, member countries regularly publish transport volume data in terms of passenger and tonne-kilometres, which are output rather than outcome measures. These output measures have one drawback, however: an inefficiently designed network with low connectivity may lead to a high transport volume in terms of kilometres, while leading to fewer trips and hence lower user benefits.

The analysis in Box 2.1 can be applied to both passenger and freight transport. Important differences exist, however, for example in terms of the cost and demand structure. Passenger transport is dominated by shorter trips. Freight is dominated by longer trips and tends to be more geared towards other nodes of transport like ports, airports and borders. Hence, aggregation across transport sectors is difficult and therefore passenger and freight output will enter the analysis separately.

2. In addition, investment in transport infrastructure can yield agglomeration benefits that are not captured by users' willingness to pay (Venables and Gasiorek, 1998). This paper does not explicitly consider effects on the spatial location of economic activities and can therefore not give direct evidence on agglomeration benefits. Oosterhaven and Knaap (2000) argue that considerable local agglomeration gains may arise from infrastructure investment, but these gains are mainly at the expense of neighbouring regions, and the national impact is likely to be small in countries with an already well-developed infrastructure. The empirical analysis in section 4 allows for variable returns to scale and therefore includes potential agglomeration effects on transport volumes. 


\section{Box 2.1. Transport demand and outcomes}

A standard tenet in transport economics is that demand for transport between two locations can be captured by a gravity equation, where bilateral travel or transport volumes depend on the economic size of the two locations and transport costs (Crozet, 2005):

$$
T_{i j}=K \frac{S_{i} S_{j}}{C_{g_{i j}}^{\gamma}}
$$

where $\mathrm{K}$ is a scale factor, $S_{i}$ and $S_{j}$ denote economic size (typically measured by GDP) of two locations (cities, regions or countries) and $c_{g}$ denotes the generalised cost of transport between the two locations (including time costs) and $\gamma$ is the elasticity of traffic with respect to costs. Users' gross benefits increase with the number of trips. Firms and households will choose trips so that the marginal benefit of an additional trip equals the marginal costs. For the users, the relevant outcomes are therefore the number of trips for passenger transport and transport volumes for freight transport, and the associated net user surpluses. A number of conclusions follow from equation 1. The number of trips between two locations and the user surplus increase with the economic size of the two locations, but decrease with the private cost of transport. This means that geographic factors, such as distance, can affect the number of trips and welfare. For more geographically dispersed economies average trip costs will tend to be higher, leading to fewer, but longer, trips. Whether transport volumes - in terms of total kilometres travelled - will be higher or lower in more dispersed economies depends on the structure of demand and costs. Furthermore, demand for road transport may decrease if alternative transport modes are available.

Equation 1 focuses on road user costs and benefits and hence ignores important factors such as infrastructure costs and externalities. On the one hand, negative externalities and public costs of providing infrastructure imply that social marginal costs are higher than private costs, suggesting that the socially optimal level of transport is lower than the observed outcome. On the other hand, if taxation of transport inputs is excessive, it will push up private costs in relation to social costs, lowering transport volumes relative to the social optimum. Ideally, these factors therefore need to be accounted for in a welfare analysis. Policy makers can influence the costs that users face by investing in better infrastructure or pricing road use differently. The costs of such measures would need to be weighed against the gains in the social surplus.

\subsection{Most transport costs are borne by users}

Road transport costs can be divided into three components: user input costs, infrastructure and maintenance costs, and costs of negative externalities. Costs can be influenced by background factors, such as economic dispersion and topography (Box 4.1). Table 2.1 provides an illustration of the composition of marginal road transport costs in Sweden (passenger cars) and the United Kingdom (freight vehicles), disregarding the sunk costs of investing in infrastructure and fixed costs of vehicles. ${ }^{3}$

User inputs are privately provided by road users both for passenger and freight traffic. Costs for these inputs form the overwhelming share of total marginal transport costs, with major components being travel time and costs of vehicles and fuel.

\subsubsection{Road infrastructure is crucial, but infrastructure costs are small in relation to user input costs}

The road network is a long-lived asset, reflecting planning and investment decisions taken decades, centuries or even millennia ago. In mature networks - as is the case in most OECD countries - current investment will only influence the size and configuration at the margin. Total spending on road network investment and maintenance amounted to about 1\% of GDP in the OECD on average over the 2000s (Figure 2.1). Network extensions and improvements are the main cost drivers, whereas maintenance costs typically only make up about $30 \%$ of total spending (ITF, 2011b). Infrastructure inputs in terms of roads

3. Average infrastructure costs (including investment and improvements) amount to EUR 2 cents $/ \mathrm{km}$ (passenger cars, Sweden) and EUR 7 cents $/ \mathrm{km}$ (freight vehicles, United Kingdom). Average vehicle costs (including capital costs) amount to 28 (passenger cars) and 62 (freight vehicles) EUR cents $/ \mathrm{km}$, respectively. 
are indispensable to produce road transport services. Traffic volumes are, however, only weakly correlated with the size of the overall network, as a large share of the network consists of local roads that provide access in sparsely populated areas. ${ }^{4}$ Capacity is therefore seldom a constraint on most of the road network. Egger and Larch (2007) find that increasing road networks in two countries simultaneously by $10 \%$ increases bilateral trade (transport) volumes by roughly $0.2 \%$, with the positive effect mainly found in less developed countries. The relationship between the length of the highway network and traffic volumes is stronger. Duranton and Turner (2009) show that increases in the US interstate highway network lead to proportional increases in traffic volumes, although these partly stem from diversion from other roads. Bougheas et al. (1999) find that larger motorway networks tend to encourage bilateral international trade volumes among nine European countries. The length of the road network in terms of lane-kilometres is one obvious quantitative indicator of infrastructure capacity, but national data for this variable do not exist.

Table 2.1. Illustrative marginal social costs for passenger cars and goods vehicles

\section{EUR cents/km}

\begin{tabular}{l|l|c|c}
\hline Cost type & & $\begin{array}{c}\text { Passenger cars } \\
(\% \text { of net total) }\end{array}$ & $\begin{array}{c}\text { Freight vehicles } \\
(\% \text { of net total) }\end{array}$ \\
\hline User inputs & Travel time & $24(59 \%)$ & $58(41 \%)$ \\
& of which congestion & $4(10 \%)$ & $12 \%)$ \\
& Vehicles & $9(22 \%)$ & $28(20 \%)$ \\
& Fuel & $9(22 \%)$ & $68(49 \%)$ \\
Infrastructure inputs & of which taxes & $5(12 \%)$ & $35(25 \%)$ \\
Externalities & Operation and maintenance & $<1(<1 \%)$ & $5(4 \%)$ \\
& Congestion & $4(10 \%)$ & $12(9 \%)$ \\
& Accidents & $2(5 \%)$ & $3(2 \%)$ \\
Total (gross) & Environmental & $1(2 \%)$ & $11(8 \%)$ \\
Government revenues & Other & $1(2 \%)$ & $2(2 \%)$ \\
Total (net) & Total (gross) & $46(112 \%)$ & $175(125 \%)$ \\
\hline
\end{tabular}

Note: Travel time costs are based on average speed estimates from SIKA (2006) and time costs based on CE Delft (2008). Passenger fuel and vehicle costs (including taxes and insurance) are for an Opel Corsa, registered 2005 , $13000 \mathrm{~km} /$ year, single passenger (driver), from www.konsumentverket.se (Sweden). Freight vehicle costs have been estimated from http://www.freightmetrics.com.au/CalculatorsRoad/TruckOperatingCost/tabid/104/Default.aspx (UK) for a Curtainsider (single). Fuel taxes are from the IEA Energy Taxes and Prices database. Marginal infrastructure and maintenance costs are from Nash (2003). Costs of externalities are from CE Delft (2008). Figures may not add up due to rounding.

Road infrastructure also entails qualitative aspects. Quality has several dimensions including surface roughness (e.g. paved versus non-paved roads), safety characteristics and resistance to wear and tear. Two important features of the network are the location and interconnections of roads in relation to economic activities and the network's ability to cope with changes in demand and supply (e.g. back-up capacity in terms of alternative routes). In transport economics, these are often referred to as connectivity and resilience, respectively (Jenelius et al., 2006; Jenelius and Mattsson, 2012). Box 3.1 presents estimates of road transport connectivity for OECD countries.

4. The correlation between passenger and freight traffic and the length of the road network (all in relation to GDP) is -0.08 and 0.50 , respectively, in the sample of OECD countries. The correlation between geographic size and the length of the road network is 0.72 . 
Figure 2.1. Infrastructure and maintenance spending on roads as a share of GDP

Average 2001-09

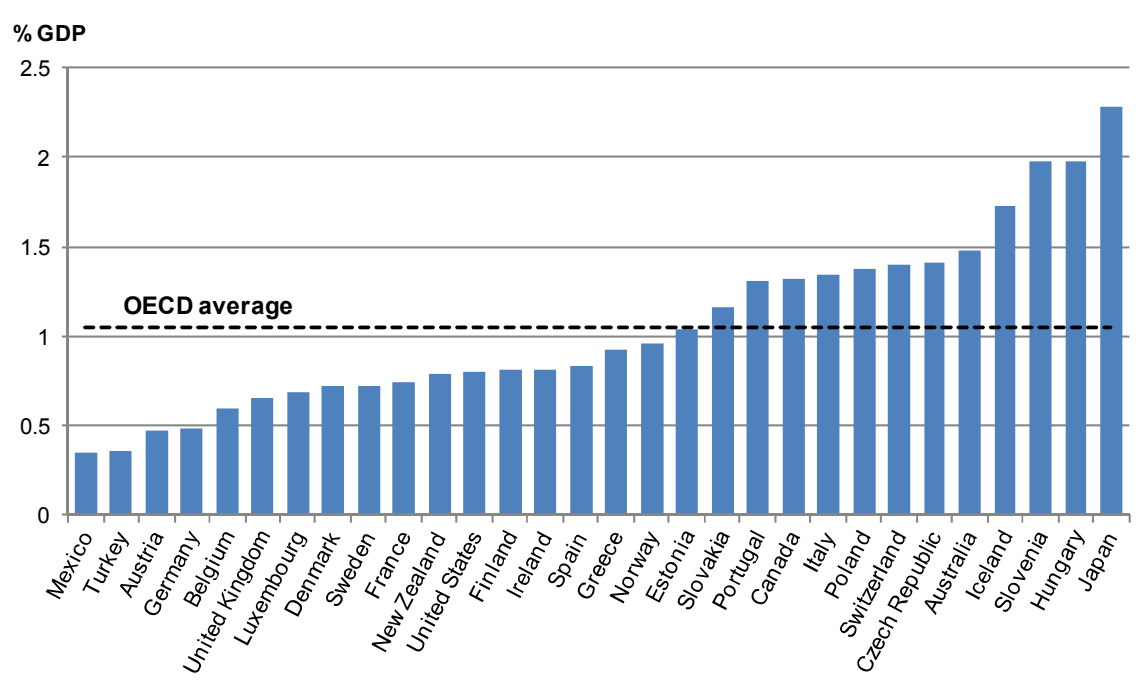

Note: Data refer to 2001-08 for Australia, Greece, Italy, Japan, Luxembourg, Norway, Sweden and Switzerland; to 2001-07 for Austria, Korea and Portugal; to 2004-09 for Hungary, and to 2001-03 for the United States.

Source: ITF; OECD Economic Outlook 91 database.

\subsubsection{Road transport creates negative externalities too}

Road transport also imposes external costs on society, stemming from undesirable outputs, such as congestion, accidents and environmental degradation. A crucial feature of road infrastructure is that for an overwhelming part of the network there are no access or user charges once fixed costs in terms of permits, vehicle costs and insurance have been incurred. Huge variations in the demand for road usage over days, weeks and seasons therefore have to be met mostly by excessive road capacity or peak-load congestion, rather than price variations. Congestion lowers travel speed, thereby raising overall trip costs, with only a fraction of the additional costs being borne by the marginal user.

Average travel times are considerably longer during peak hours than in uncongested conditions (Figure 2.2, Box 2.2). Overall road congestion costs in developed countries have been estimated at roughly 1 to $2 \%$ of GDP (OECD/ECMT, 2007; TTI, 2011; EC, 2011). Efficient policy settings should therefore ensure that the marginal user faces the full social costs of congestion, which are likely to vary considerably over space and time (Vickrey, 1969). Box 5.1 discusses the use of congestion pricing in OECD countries.

Caveats apply to the concept of congestion costs, however. Congestion cost estimates are based on comparing the actual to the free-flow speed, which may be neither attainable nor optimal as an average speed (OECD/ECMT, 2007). The optimal level of congestion is not zero, but marginal costs should be equated to the marginal costs of remedying measures, such as increasing road capacity or implementing traffic management systems. Furthermore, to the extent that congestion time is predictable, road users will include it in their normal travel time estimates and treat it as part of total travel costs. 
Figure 2.2. Average increase in travel time during peak hours

As per cent of non-congested travel time

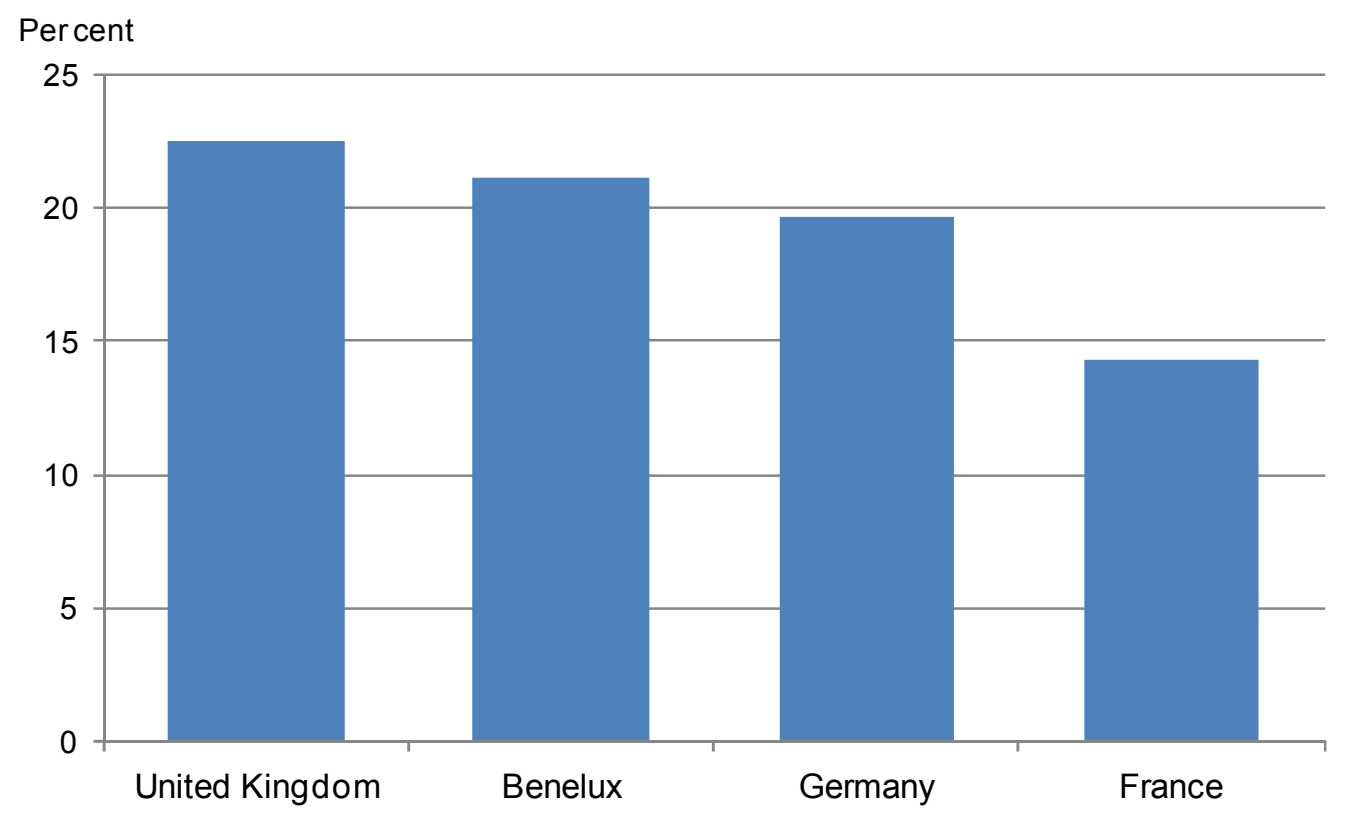

Source: INRIX (2010).

Social efficiency is affected negatively by unpredictable variations in travel time. Users seem to suffer more from unpredictable variations in travel time than regular congestion (OECD/ECMT, 2007). As the costs of arriving early are smaller than the costs of arriving late, this leads to excessive travel time budgeting. It should be noted that there is a negative correlation between congestion and predictability of travel time, as congestion increases risks of unexpected delays (OECD/ECMT, 2007). The availability of internationally comparable travel time data is limited, and the data used in the empirical analysis will only include average travel time (including and excluding congestion), but not indicators of the predictability of travel time. Box 2.2 outlines how an indicator of congestion and travel time variability can be constructed with web-based data.

Accident costs are only partially internalised by the individual road user, creating negative externalities for other users and public finances. First, insurance markets are unlikely to fully gauge skills and risk-taking behaviour in order to discriminate among users and set insurance premiums to match accident risks with costs. Non-discriminatory insurance regulation may worsen these problems. Second, existing insurance policies do not typically cover the full social costs of accidents. Part of medical costs and the loss of production would then be borne by tax payers, while compensation for individuals affected by accidents may be insufficient. Estimates by Baum et al. (2008) and Parry, Evans and Oates (2010) suggest that external accident costs are roughly EUR 2 cents $/ \mathrm{km}$ in the European Union and the United States (Table 2.1). Moreover, accidents can trigger and compound congestion, with some studies suggesting that $25-30 \%$ of delays are caused by road accidents (Schrage, 2006).

Environmental externalities from road transport tend to be either highly localised or global in nature. Noise and emissions of particulate matter, nitrogen oxides $\left(\mathrm{NO}_{\mathrm{x}}\right)$ and other hazardous pollutants mainly affect road users and individuals living close to roads. Emissions of $\mathrm{CO}_{2}$ from fuel combustion are, on the other hand, a major source of global climate change. $\mathrm{CO}_{2}$ emissions from road traffic amount to $17 \%$ of global emissions and 25\% of emissions in the OECD area (IEA, 2011). Large uncertainties surround environmental cost estimates, especially relating to costs of climate change. The figures in Table 2.1 are based on an assumed social cost of EUR 22 per tonne of $\mathrm{CO}_{2}$ emissions (Nash et al., 2008). 


\section{Box 2.2. Estimating congestion and travel time variation between US cities using web-based map services}

This box uses US data extracted through the web-service Bing Maps to illustrate how estimates of travel time and congestion can be produced. As web-based information is also available for other OECD countries, internationally comparable estimates could be computed, though real travel time data are currently only available for a few OECD countries.

Web-based traffic services use different data sources to estimate travel times between locations. Theoretical travel times are based on legal speed limits and do not include delays due to congestion, accidents and construction. Real-time estimates of travel time "in traffic" are based on actual travel speeds measured through road-side sensors, manual measurement and increasingly through the location and movement of mobile devices travelling along roads. Road travel time was estimated between the 10 biggest US cities every 15 minutes for six weeks, starting in mid-August 2012. These locations were chosen mainly to illustrate the potential of the data and their choice is likely to have some shortcomings. On the one hand, when studying passenger traffic, which mostly reflects commuting and other shorter trips, these cities are located too far from each other, meaning that congestion is likely to be underestimated. On the other hand, freight traffic trips are often longer and are more targeted towards other nodes of transport, such as ports, airports and borders. Despite these shortcomings, results from such data can provide suggestive prima facie evidence on travel time and congestion covering a larger part of the road network than what has been possible thus far.

Table 2.2 provides estimates of average delays and peak delays. These are defined as the percentage difference between, respectively, the average travel time and the $95^{\text {th }}$ percentile of the travel time distribution of each city-pair and the minimum travel time (defined as the $5^{\text {th }}$ percentile). Average and peak delays can be seen as proxies for average congestion and peak-hour congestion, respectively. Average delays amount to $1.6 \%$ of minimum travel time and peak congestion is roughly triple that at $4.4 \%$. Averages hide significant variation across trips however. For Chicago-San Diego, estimated average delays and peak delays are $0.38 \%$ and $0.85 \%$, respectively, whereas for Los Angeles-San Diego the corresponding figures are $6.5 \%$ and $18.3 \%$. This difference partly reflects the relative location of the cities, where the former trips largely take place on less congested non-urban highways. These numbers underestimate total national congestion as they exclude local trips, and no extra weight is given to peak hours when a disproportionate number of trips take place. For example, Schrank et al. (2011) report that peak-hour congestion delays within US urban areas are equal to $20 \%$ of freeflow (i.e. minimum) travel time.

Table 2.2. Summary statistics of travel time and congestion

\begin{tabular}{lc|c|c}
\hline & $\begin{array}{c}\text { Average, } \\
\text { all city pairs }\end{array}$ & $\begin{array}{c}\text { Chicago- } \\
\text { San Diego }\end{array}$ & $\begin{array}{c}\text { Los Angeles- } \\
\text { San Diego }\end{array}$ \\
\cline { 2 - 4 } Road distance $(\mathrm{km})$ & 2120 & 3340 & 194 \\
Population departure city (million) & 2.34 & 2.70 & 3.79 \\
Population arrival city (million) & 2.39 & 1.31 & 1.31 \\
Theoretical travel time (without traffic, hours and minutes) & $18 \mathrm{~h} 50 \mathrm{~m}$ & $29 \mathrm{~h} 30 \mathrm{~m}$ & $1 \mathrm{~h} 46 \mathrm{~m}$ \\
Average travel time (hours and minutes) & $19 \mathrm{~h} 30 \mathrm{~m}$ & $29 \mathrm{~h} 47 \mathrm{~m}$ & $2 \mathrm{~h} 20 \mathrm{~m}$ \\
Travel time 5 ${ }^{\text {th }}$ percentile (hours and minutes) & $19 \mathrm{~h} 14 \mathrm{~m}$ & $29 \mathrm{~h} 41 \mathrm{~m}$ & $2 \mathrm{~h} 12 \mathrm{~m}$ \\
Travel time 95 ${ }^{\text {th }}$ percentile (hours and minutes) & $19 \mathrm{~h} 54 \mathrm{~m}$ & $29 \mathrm{~h} 56 \mathrm{~m}$ & $2 \mathrm{~h} 36 \mathrm{~m}$ \\
Average delay (\%) & 1.6 & 0.38 & 6.5 \\
Peak delay (\%) & 4.4 & 0.85 & 18.3 \\
Number of observations & 407495 & 5056 & 5059 \\
\hline
\end{tabular}

Note: Average and peak delays are defined as the percentage difference between, respectively, the average travel time and the travel time at the $95^{\text {th }}$ percentile of the travel time distribution of each city pair and the minimum travel time (defined as the travel time at the $5^{\text {th }}$ percentile).

Source: Bing Maps Route Service; authors' calculations.

\subsection{Aggregation of outcomes and inputs is difficult}

Benchmarking of efficiency and productivity of road transport and infrastructure would be facilitated by monetising different outcomes using shadow prices and adding them into a single outcome variable. In the case of road transport this is difficult for several reasons. First, while Table 2.1 provides rough estimates for internal and external marginal costs of road transport, these numbers are compiled from a mixture of national and cross-country sources and can therefore not produce country-specific cost estimates. Second, it is difficult to estimate the social value of transport as suggested in Box 2.1. Third, 
even disregarding externalities challenges abound. The availability of inputs, outputs and prices would make productivity analysis fairly straightforward in freight transport, although in-house transport services in non-transport firms may pose a problem (Persson and Song, 2010). The valuation of outcomes in passenger transport is more difficult, however, reflecting differences in valuations between average and marginal trips and across trip purposes (Bickel et al., 2006; CE Delft, 2008). ${ }^{5}$ Policy makers often also have distributional concerns, e.g. in terms of regional outcomes, which could be reflected in valuations across individuals.

Aggregation problems are further aggravated by the existence of undesirable outcomes. As discussed above, the social costs of e.g. congestion and emissions are not easy to estimate. Furthermore, marginal cost estimates as in Table 2.1 may be a good benchmark for evaluating a project on the margin, but they may not reflect average costs needed for aggregating inputs and outputs and computing performance measures.

\subsection{A framework for analysing efficiency in the road transport sector}

To summarise, road transport outcomes can be classified into (intended) desirable outcomes and (unintended) undesirable ones. Passenger- and tonne-kilometres are outputs used as proxies for desirable outcomes. Undesirable outcomes are unforeseeable variations in travel time and congestion, accidents and environmental degradation. Major inputs into the production function are the size and the quality of the network, spending on road investment and maintenance, and user inputs in terms of time, fleet and fuel.

As discussed in Box 4.1, background factors, in terms of geography and the size of other transport networks, can affect outcomes through two channels. First, background factors may have a direct impact on performance. Performance benchmarks that do not take into account these factors can then be biased. Second, background factors may influence outcomes indirectly through inputs (Figure 2.3). This may affect both the relative intensity of different inputs, but also the ratio of outcomes to inputs. The framework is summarised in Figure 2.3.

Figure 2.3. A framework for analysing road transport infrastructure performance

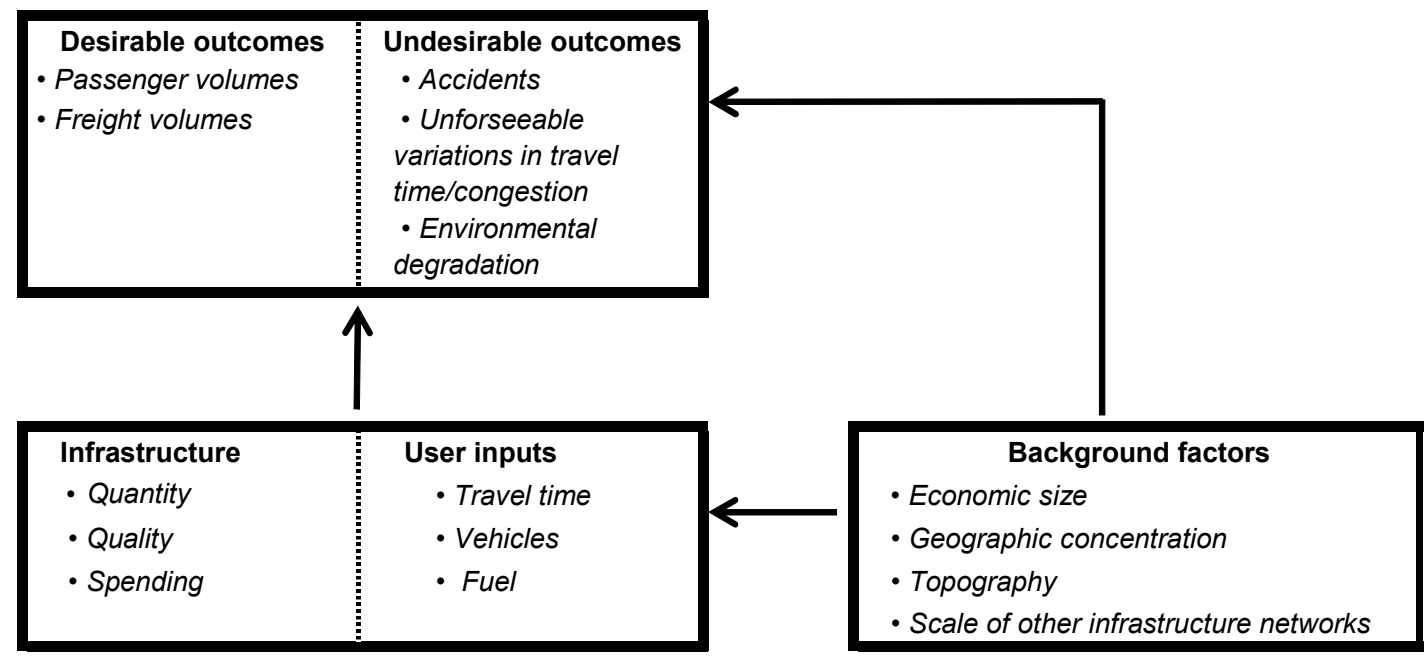

5. This problem does not arise for CBAs of specific projects, where marginal valuations can be used. 


\section{Benchmarks for the road transport sector and infrastructure performance}

The previous section has laid out a framework for evaluating the performance of the road transport sector based on outcomes and inputs. Cross-country analysis of road transport is hampered by a complete lack of national data in some dimensions (e.g. connectivity), partial coverage (e.g. travel time) or limited comparability (e.g. investment and maintenance expenditure). These data problems mean that performance indicators have to be interpreted with caution. Box 3.1 outlines a methodology for how internationally comparable road connectivity indicators could be estimated. Appendix 1 discusses data availability, quality and comparability in detail and outlines what data would be needed to produce better benchmarks for the sector. Table 3.1 highlights some of the most pressing data issues.

Given significant data shortcomings, the analysis at this stage will be conducted with information that is widely available. In many instances, comparability of the data and conformity with the analytical framework can currently not be ensured. This section discusses the benchmarking of road sector performance in three steps. First, output measures will be discussed, as outcome measures are not readily available. Even for outputs, data coverage is sometimes sparse. In the second step, the relevant inputs will be reviewed. In the third step a set of simple performance indicators relating single outputs to single inputs will be developed.

Table 3.1. Examples of data issues limiting the evaluation of road sector performance

\begin{tabular}{|c|c|c|c|}
\hline & Availability of data & Comparability issues & $\begin{array}{l}\text { Potential source or } \\
\text { compilation method }\end{array}$ \\
\hline \multicolumn{4}{|l|}{ Outcomes } \\
\hline Trips & $\begin{array}{l}\text { Available in some national } \\
\text { transport surveys. }\end{array}$ & $\begin{array}{l}\text { Survey based information - } \\
\text { definitions and estimation } \\
\text { methods need to be harmonised. }\end{array}$ & $\begin{array}{l}\text { National transport } \\
\text { authorities. }\end{array}$ \\
\hline Connectivity & None. & $\begin{array}{l}\text { Definitions and estimation } \\
\text { methods need to be agreed. }\end{array}$ & $\begin{array}{l}\text { A connectivity indicator for } \\
\text { OECD countries is } \\
\text { developed in Box } 3.1 \text {. }\end{array}$ \\
\hline $\begin{array}{l}\text { Unpredictability/ } \\
\text { congestion }\end{array}$ & $\begin{array}{l}\text { Available for a subset of } \\
\text { countries and for } \\
\text { cities/regions. }\end{array}$ & $\begin{array}{l}\text { Regional and city studies often } \\
\text { based on different } \\
\text { measurement methods. }\end{array}$ & $\begin{array}{l}\text { Commercial services or } \\
\text { own calculation based on } \\
\text { web-based map services, } \\
\text { based on methodology } \\
\text { applied for US cities in } \\
\text { Box } 2.2 \text {. }\end{array}$ \\
\hline \multicolumn{4}{|l|}{ Inputs } \\
\hline Travel time & $\begin{array}{l}\text { Available for } 12 \mathrm{EU} \\
\text { countries. }\end{array}$ & $\begin{array}{l}\text { Survey based information - } \\
\text { definitions and estimation } \\
\text { methods need to be harmonised. }\end{array}$ & $\begin{array}{l}\text { National time use or } \\
\text { household surveys. See } \\
\text { connectivity above. }\end{array}$ \\
\hline Lane-kilometres & None. & Road definitions. & $\begin{array}{l}\text { Commercial or public } \\
\text { mapping entities. }\end{array}$ \\
\hline Road quality & None. & $\begin{array}{l}\text { Regional data based on } \\
\text { different measurement tools. }\end{array}$ & $\begin{array}{l}\text { Regional transportation } \\
\text { authorities. }\end{array}$ \\
\hline
\end{tabular}




\section{Box 3.1. A road connectivity index for the OECD area}

Time costs make up a significant part of marginal road transport costs (Table 2.1). The available empirical evidence also suggests that total time costs are substantial. Combes and Lafourcade (2005) find that time-related costs account for around $63 \%$ of total road transport shipment costs in 1998 , and for slightly less than half of the $38 \%$ decline in total road transport costs from 1978 to 1998 . Internationally comparable data on time costs are, however, not widely available (Table 3.1). A road connectivity index for both OECD countries and some nonmember countries was developed, which can also be interpreted as a standardised travel time measure (Braconier and Pisu, 2013 for more details). Connectivity can be defined as the capacity to move goods and people between different geographic locations at reasonable costs (Oxera, 2010). It is therefore closely related to travel speed which is largely dependent on the location, capacity and quality of the road infrastructure. Using web-based traffic information discussed in Box 2.2, a connectivity index for OECD and some non-member countries was estimated based on theoretical travel times - i.e. travel time disregarding congestion and other temporary factors - between the ten most populous cities in each country, yielding up to 90 city-pair trip times for each country. ${ }^{1}$ In order to separate costs related to the road transport system from costs generated by exogenous factors - like distance - the index takes into account the relative geographic location of each city-pair. ${ }^{2}$

To evaluate connectivity between city pairs a gravity equation is estimated across the countries, where theoretical travel time is regressed on the great circle distance ("as the crow flies"), squared great circle distance, the difference between the great circle distance and the actual road distance (called the divergence), the population of the two cities (all terms in logarithms) and country fixed-effects. The results are presented in Table 3.2. As expected, travel time is increasing with great circle distance and divergence (i.e. road distance when keeping great circle distance constant). The linear and quadratic terms imply that travel time increases less than proportionally with great circle distance (i.e. if distance increases by $1 \%$ travel time rises by less than $1 \%$ ), with the elasticity being 0.76 for city-pairs at the sample mean distance $(406 \mathrm{~km})$. Average travel speeds therefore increase with distance, likely reflecting that a larger share of shorter trips takes place in local metropolitan areas with lower speed limits. The negative effect of city populations on travel time suggests that better infrastructure in bigger cities dominates lower speed limits in urban areas. A doubling of the departure or destination city's population would lower the theoretical travel time by roughly $1 \%$, or 4 minutes, for the average trip. ${ }^{3}$

Table 3.2. Gravity equation estimates for travel time

\begin{tabular}{lc}
\hline Dependent variable & $\ln$ (travel time) \\
\hline Constant & $5.37(0.15)^{\star * *}$ \\
In(great circle distance) & $0.58(0.00)^{\star * *}$ \\
In(great circle distance) & $0.03(0.00)^{\star * *}$ \\
In(divergence) & $0.91(0.05)^{\star * *}$ \\
In(population departure city) & $-0.009(0.004)^{*}$ \\
In(population destination city) & $-0.008(0.004)^{\star}$ \\
Adjusted $\mathrm{R}^{2}$ & 0.98 \\
Number of observations & 4613 \\
\hline
\end{tabular}

Note: Numbers in parentheses are robust standard errors adjusted for country-specific effects. ${ }^{*},{ }^{* *},{ }^{* * \star}$ denotes significant at the $5 \%, 1 \%$ and $0.1 \%$ levels respectively.

The country fixed-effects estimated in the regression presented in Table 3.2, can be used to compute the (percentage) country-average deviation of travel time from the model's predicted travel time. As discussed in Braconier and Pisu (2013), there is a risk that results may be skewed by extreme observations and therefore the trips that constitute the upper and lower $10 \%$ of deviations from predicted travel time have been excluded for each country. This connectivity index is shown in the first panel of Figure 3.1. The indices show average deviations in travel time, with e.g. Germany and Korea experiencing theoretical travel times that are around $20 \%$ lower than predicted, while trip times in Romania and Brazil are roughly $25 \%$ higher. While OECD countries in general provide better connectivity than low and medium-income economies, exceptions like South Africa, China and Norway exist. 
Figure 3.1. Road transport connectivity in the OECD

Connectivity index

(deviation in travel time from prediction, in per cent)

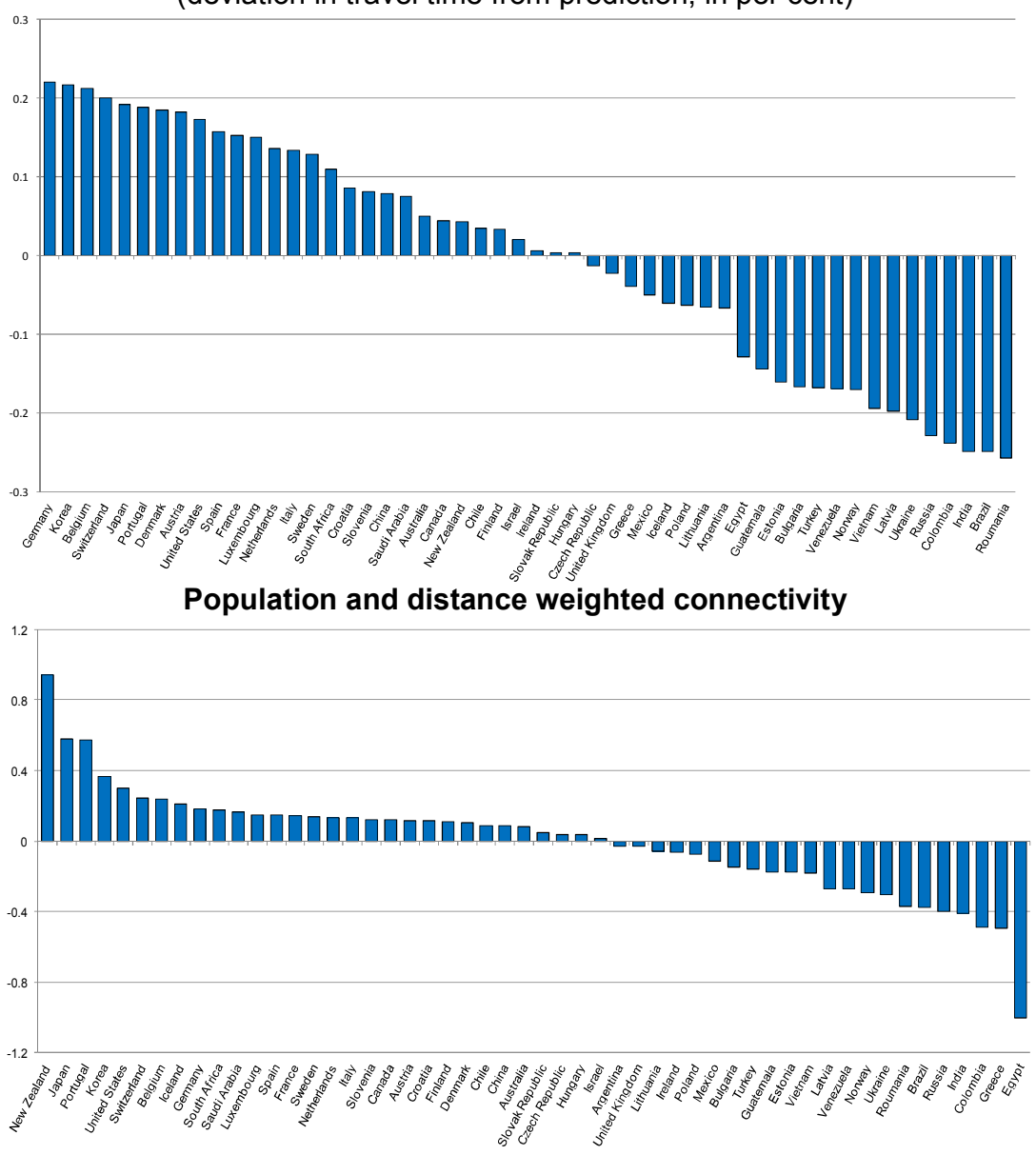

As discussed in Box 2.1, transport between large and closely located locations (cities) generates large welfare benefits relative to small and distantly located ones. The indicator above is therefore refined to consider the relative distance between cities and the relative size of each city-pair in relation to country averages. This gives distance and population weighted connectivity for each city-pair as:

$$
\text { Weighted connectivity of city } i=\sum_{j=1}^{10, j \neq i} \frac{\left(P_{i} P_{j}\right)}{\bar{p}^{2}} \frac{\bar{d}}{d_{i j}} e_{i j}
$$

where $p_{i}$ and $p_{j}$ denote city populations, $d_{i j}$ and $e_{i j}$ are the distance and connectivity between cities $i$ and $j$, and upper bars indicate country averages. The distance and population weighted connectivity across OECD countries is shown in the second panel of Figure 3.1. Population and distance weighted connectivity is high in New Zealand and Japan and low in Greece and Egypt.

1. For some countries, ad hoc adjustments to the sample were needed. For Greece, Italy, Japan, Portugal and Spain cities located on islands were replaced by mainland cities, as travel times related to sea crossings are not useful indicators of road infrastructure quality. For New Zealand city links between the North and South islands were excluded, leaving only withinisland trips. For Canada 15 cities were initially included, but all city-pair links which used the US road network were taken out. On average, 89 observations per country were available.

2. Ideally, this index should be based on actual travel time data - collected over a long period - rather than theoretical travel time. However, currently such data cannot be extracted for most included countries.

3. These estimates do not include delays due to congestion, accidents and maintenance however. In a similar analysis based on average actual rather than theoretical travel times for ten US cities, the estimated effect of city population on travel time is positive, illustrating that congestion (and speed limits) dominate the better infrastructure in larger cities. The net effect on actual travel time of a doubling of city size would be an increase around $2 \%$. 


\subsection{The composition of output varies across $\mathrm{OECD}$ countries}

Four different outputs are analysed: two positive (passenger-kilometres and freight tonne-kilometres) and two negative $\left(\mathrm{CO}_{2}\right.$ emissions and accident-related injuries). Output indicators for all OECD countries are presented in Appendix 1 (Figure A1.2). Data are averages for 2001-10, scaled by real GDP in USD based on 2005 purchasing power parities (PPPs), and presented in units of standard deviations from the OECD average.

Figure 3.2 shows road output indicators for four selected OECD countries. The negative outputs $\left(\mathrm{CO}_{2}\right.$ emissions and accidents) are presented as the inverse of their actual value, so that a country falling inside the OECD average produces less desirable outputs and more undesirable outputs than the OECD average. Canada shows higher than average passenger-kilometre output, while freight tonne-kilometres are just below the OECD average, possibly reflecting a more intensive use than elsewhere of railways rather than roads for transporting freight. $\mathrm{CO}_{2}$ emissions are high in Canada relative to the OECD average. In Korea, $\mathrm{CO}_{2}$ emissions are below the OECD average, but injuries due to road accidents are high compared with the OECD average. The Netherlands has less freight and passengers transported by road and lower negative outputs than the OECD average. The Slovak Republic has a high level of road freight transport, with lower $\mathrm{CO}_{2}$ emissions relative to the OECD average.

\subsection{User inputs have grown faster than the size of the network}

Road sector inputs are classified into three groups: user inputs (passenger cars, freight vehicles and energy consumption); network infrastructure (total road network and motorways); and spending (investment in and maintenance of road infrastructure). As with the output indicators shown above, the road input indicators are scaled by real GDP in 2005 USD PPP and presented in units of standard deviations from the OECD average.

Road input indicators for all OECD countries are presented in Appendix 1 (Figure A1.3) in the same format as the output indicators. The densely populated European countries tend to be quite close to the OECD average, whereas countries with large territories, scattered populations, lower per capita GDP or specific topographical features are often farther from the norm.

Figure 3.3 shows input diamonds for four OECD countries. Denmark, like many other European countries, is close to the OECD average for most of the inputs shown. The car fleet size is, however, below the OECD average, possibly reflecting policy measures including high taxes on car ownership, a well developed public transport system and measures to promote urban bicycle use. On the other hand, the size of the Japanese goods vehicle fleet is above the OECD average, and investment and maintenance spending is significantly above average, possibly reflecting high investment costs due to a challenging topography, while energy consumption is below the OECD average. While Luxembourg stands out as having the highest road sector energy consumption, this reflects high fuel sales to cross-border customers due to lower fuel taxes, and highlights the difficulty of separating national from transnational data. Finally, the United States shows a high level of energy consumption and a very high number of goods vehicles, but a low number of passenger cars. The latter is misleading, however, because pick-up trucks and vans are classified as freight vehicles, while they are often used in the United States and other countries (Canada, Mexico) for passenger transport. The inability to distinguish between commercial vehicles and passenger vehicles classified under goods vehicles means that a composite vehicle indicator may be more appropriate. These issues will be analysed in more detail in the next section. 
Figure 3.2. Road output indicators in selected OECD countries

Average 2001-10, scaled by real GDP in USD based on 2005 PPPs

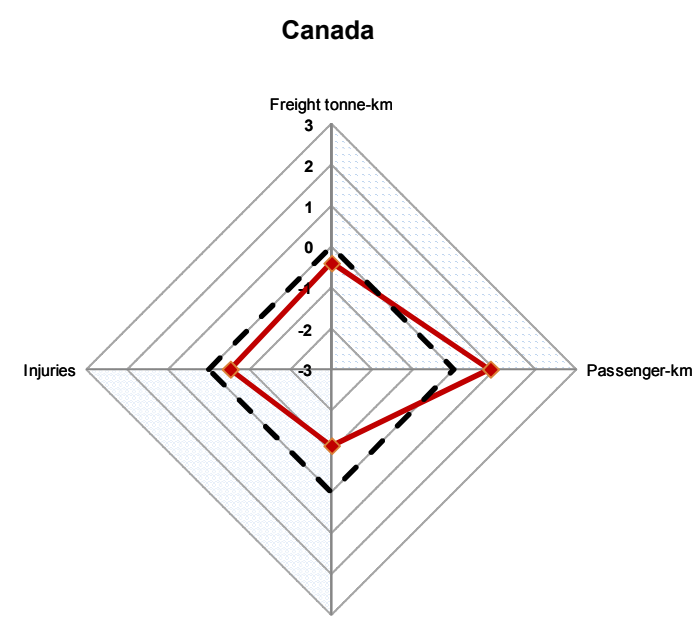

CO2 emissions

Netherlands

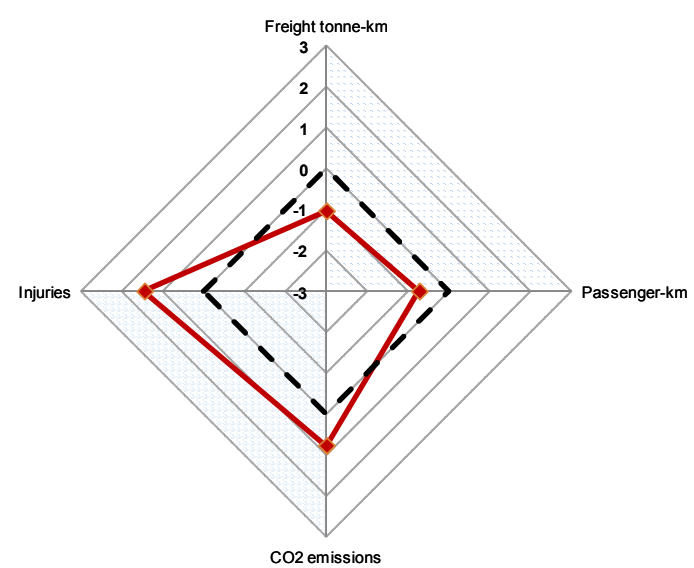

Korea

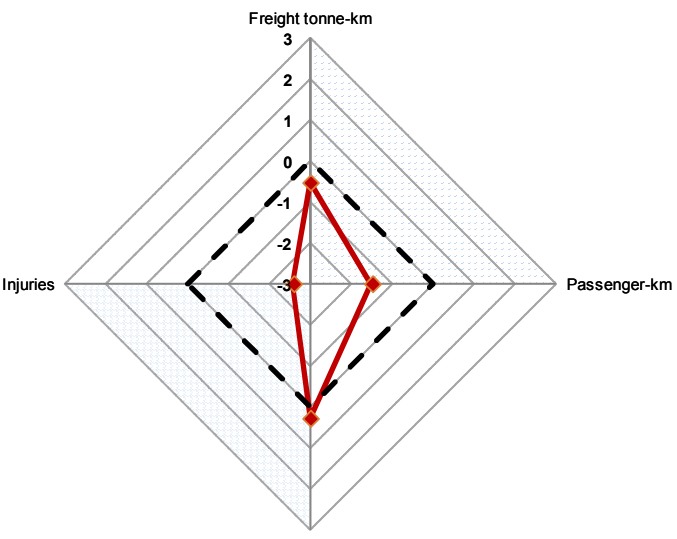

$\mathrm{CO} 2$ emissions

Slovak Republic

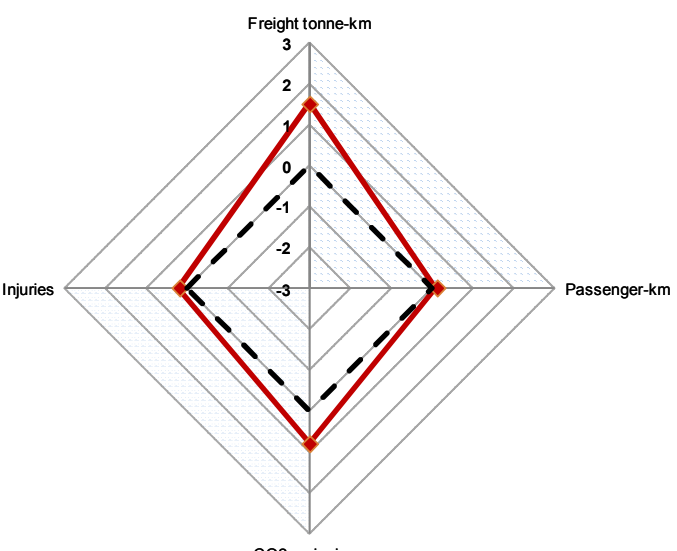

CO2 emissions

Note: The dotted line represents the OECD average; the solid line represents the country shown. Indicators are presented in units of standard deviation. Injury accidents and $\mathrm{CO}_{2}$ emissions are shown as the inverse of their values, so that countries lying outside the black dotted line have fewer injury accidents or $\mathrm{CO}_{2}$ emissions than the average, and countries within the black dotted line have more accidents or $\mathrm{CO}_{2}$ emissions than the OECD average. See Table A1.5 in Appendix 1 for detailed information on dates and sources by country.

Source: International Transport Forum; IEA, $\mathrm{CO}_{2}$ Emissions from Fuel Combustion (database). 
Figure 3.3. Road input indicators in selected OECD countries

Average 2001-10, scaled by real GDP in USD based on 2005 PPPs

Denmark

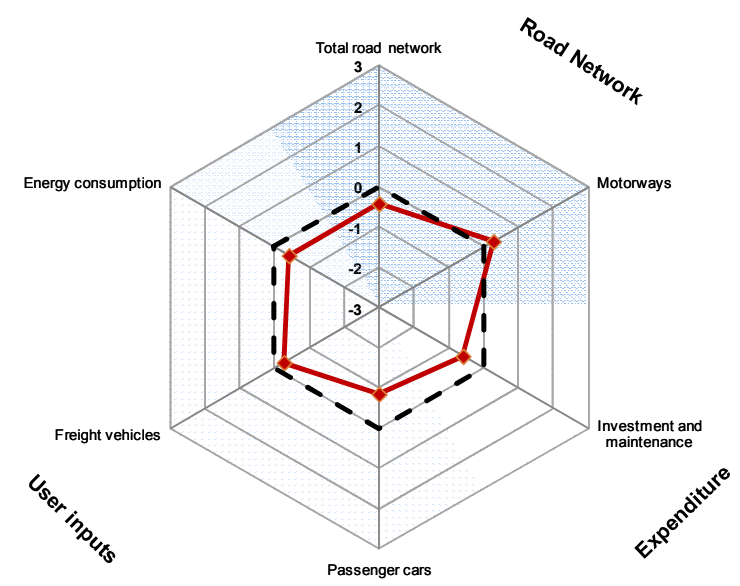

Luxembourg

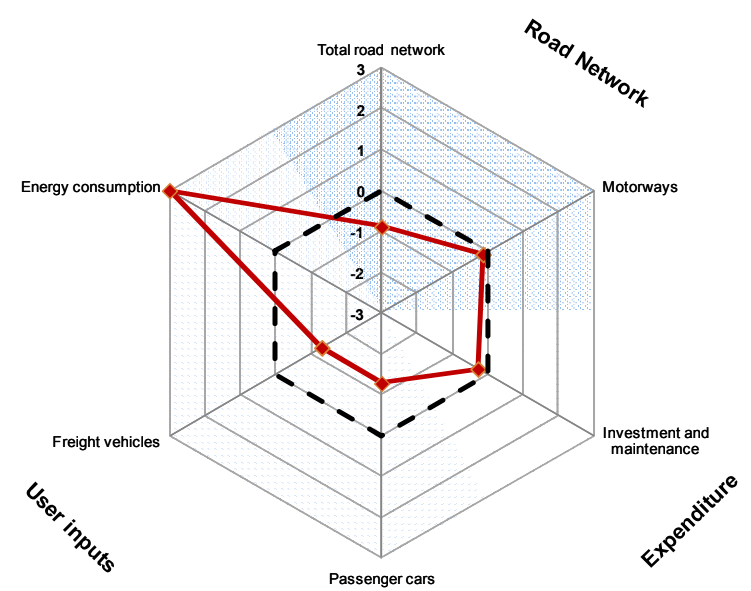

Japan

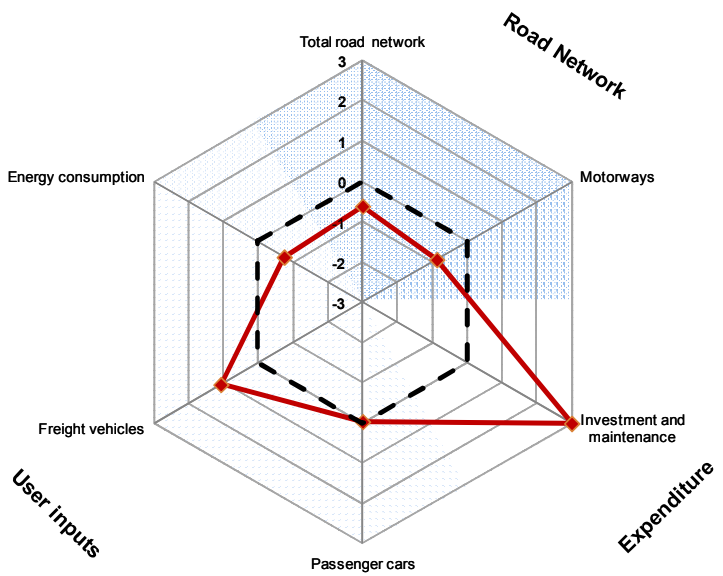

United States

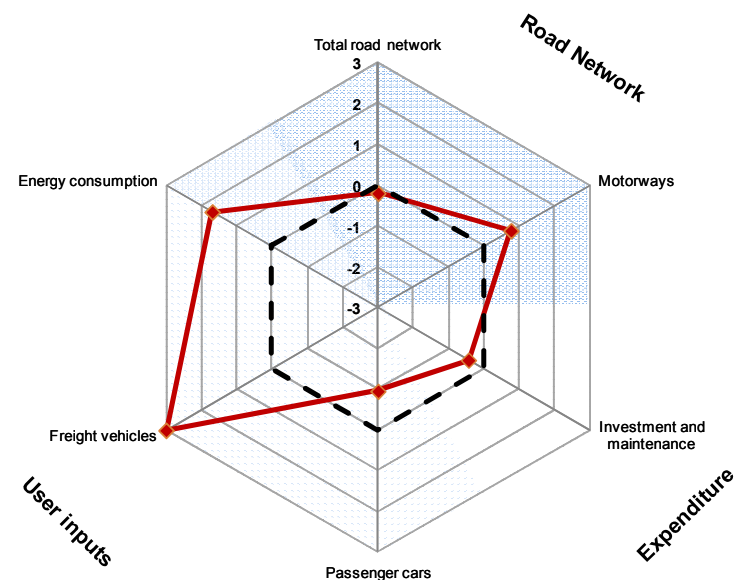

Note: The dotted line represents the OECD average, while the solid line represents the country shown. Data are based on $2001-10$ averages and are scaled by real GDP except for investment and maintenance expenditures, which are based 1992-2009 averages and nominal GDP ratios. The indicators are presented in units of standard deviation around the OECD average. Data points greater than three standard deviations from the OECD average have been set to 3 in order to maintain a readable scale. Any point therefore touching the outer boundary should be considered "above 3". See Table A1.5 in Appendix 1 for detailed information on dates and sources by country.

Source: International Transport Forum; World Bank Development Indicators; IRTAD; and IRF World Road Statistics 2011.

Looking at input indicators over time is difficult, given the lack of comparable historical data and the many missing observations where longer time series are available. Energy consumption data, however, are available for most countries going back to the early 1960s. Road sector energy consumption has declined over the past few years, after increasing by nearly 38\% between 1990 and 2007 (Figure 3.4). The recent drop reflects the effects of the economic crisis on transport volumes, high fuel prices, but also social trends 
like the increasing popularity of living in urban areas (Puentes and Tomer, 2008; ITF, 2011a). OECD-wide, the goods vehicle fleet grew by close to $70 \%$ between 1990 and 2007, while the number of passenger cars grew by nearly $40 \%$. The length of road networks increased by about $12 \%$ over the same period, while the motorway network expanded by some $20 \%$ between 1995 and 2009 . There has thus been a significant shift in the relative input shares over time with a rising ratio of user inputs relative to the network size.

Figure 3.4. Road sector energy consumption in the OECD area

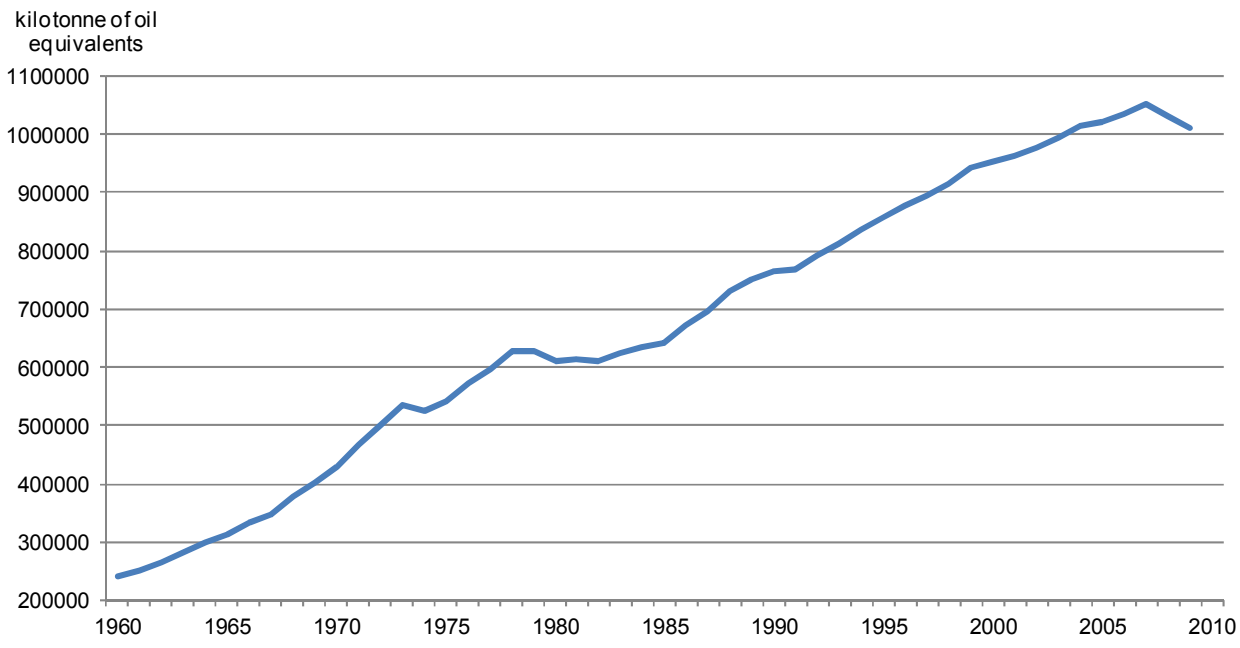

Source: IEA (2011), "OECD Product Supply and Consumption”, IEA Oil Information Statistics (database).

\subsection{Different efficiency benchmarks provide different country rankings}

A number of benchmarks relating passenger and freight transport to various road inputs have been developed (Figure 3.5). Italy and Spain move the most passengers and Korea the most freight per kilometre of roads, and on these simple metrics use the existing network most efficiently. The United States and Denmark produce the most passenger-kilometres per car, while the Slovak Republic produces the most freight tonne-kilometres per goods vehicle. ${ }^{6}$ Turkey and Mexico spend the least on investment and maintenance per passenger-kilometre and freight tonne-kilometre, while Japan and Luxembourg spend the most. Poland has the highest ratio of passenger and freight movements to total road sector energy consumption.

6. The figures for the US are likely to be biased by the misclassification of passenger vans and pick-up trucks as freight vehicles. 
Figure 3.5. Benchmark indicators for passenger and freight road transport Average 2001-09
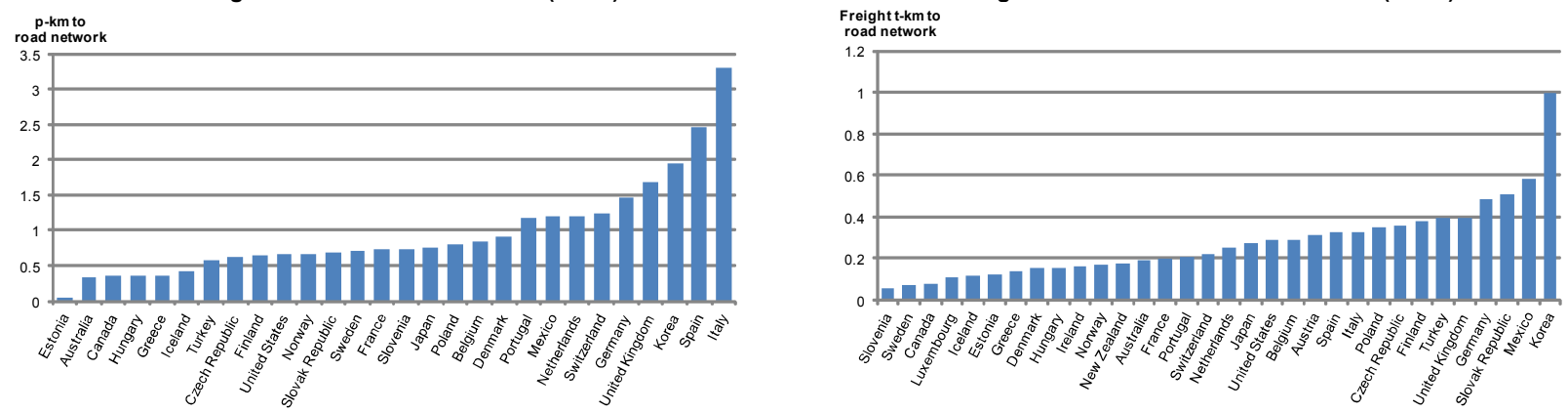

Passenger-km to total passenger cars (in 1000s)

Freight tonne-km to total goods vehicles (in 1000s)
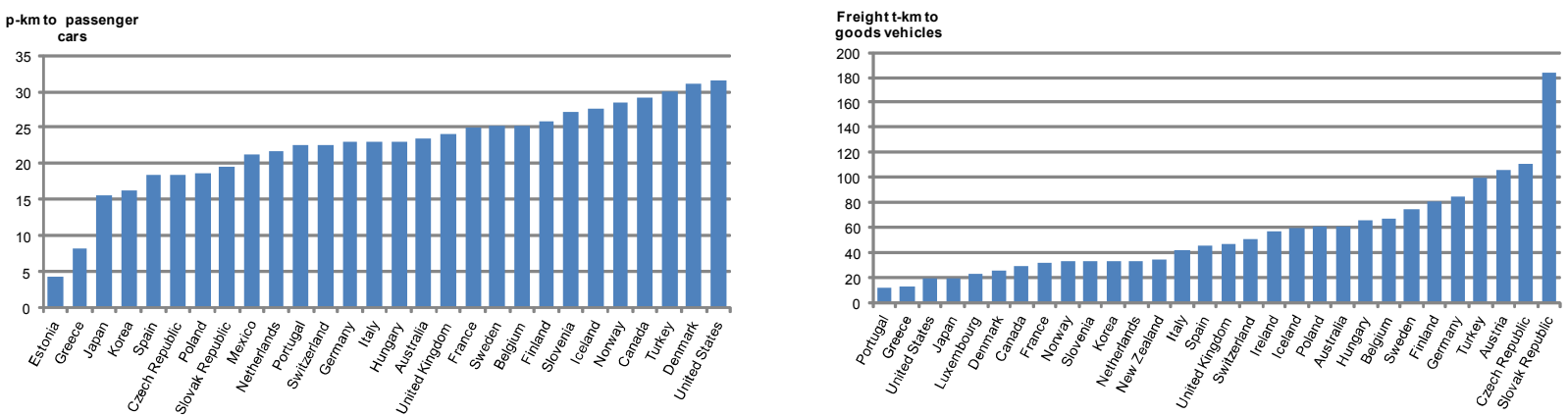

Passenger-and freight tonne-km to investment and maintenance Scale 0-100

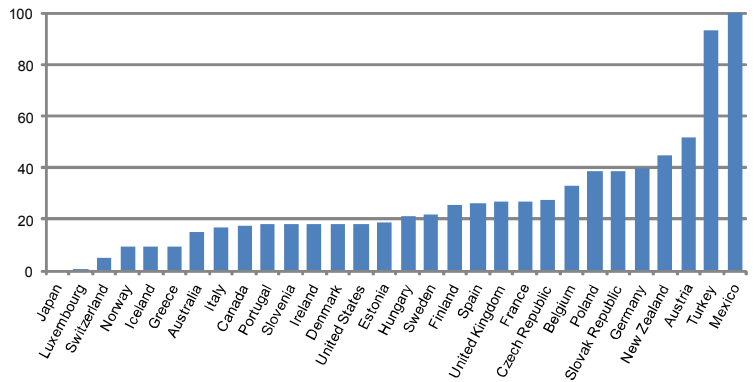

Passenger- and freight tonne-km to road sector energy consumption Scale 0-100

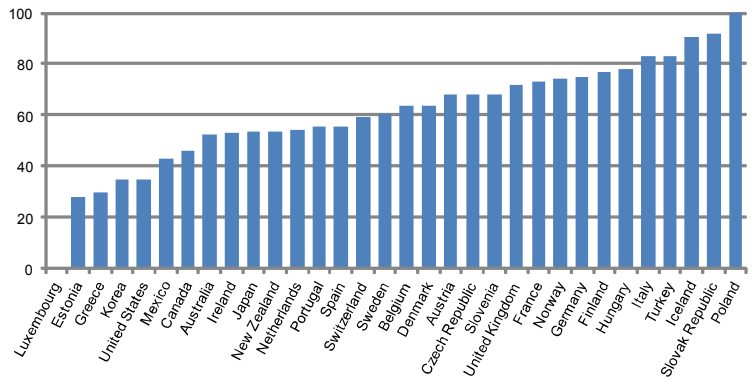

Note: Passenger and freight tonne-kilometres are aggregated into a single variable using principal components analysis.

Source: International Transport Forum; World Bank Development Indicators; IRTAD; and IRF World Road Statistics 2011.

Negative outputs - injuries following accidents and $\mathrm{CO}_{2}$ emissions - are shown in Figure 3.6 scaled by a combination of passenger and freight tonne-kilometres. On this metric, the Netherlands has the fewest accidents, followed by Mexico, Australia and Denmark. Korea has the highest accident rate, followed by Japan and Turkey. In terms of $\mathrm{CO}_{2}$ emissions, Poland and the Slovak Republic show the highest efficiency, whereas Estonia and Greece record the highest emissions in relation to inputs. 
Figure 3.6. Benchmark indicators for negative outputs

Average 2001-09

Injuries to passenger and freight tonne $\mathrm{km}$

Scale 0-100

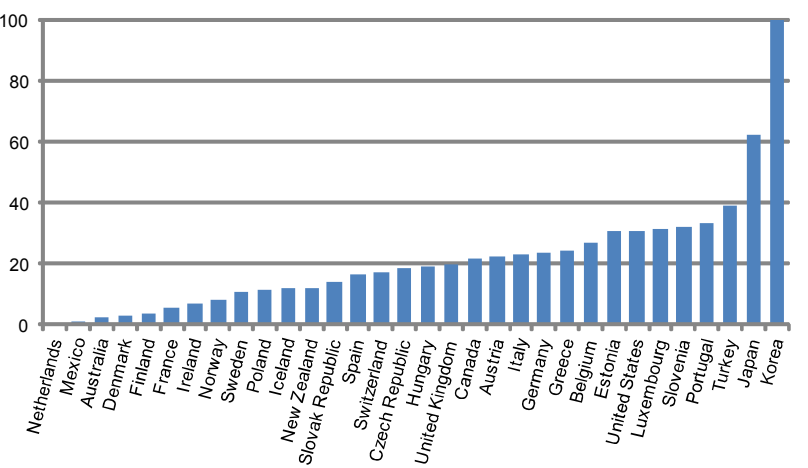

Road sector $\mathrm{CO} 2$ emissions to passenger and freight tonne $\mathrm{km}$ Scale $0-100$

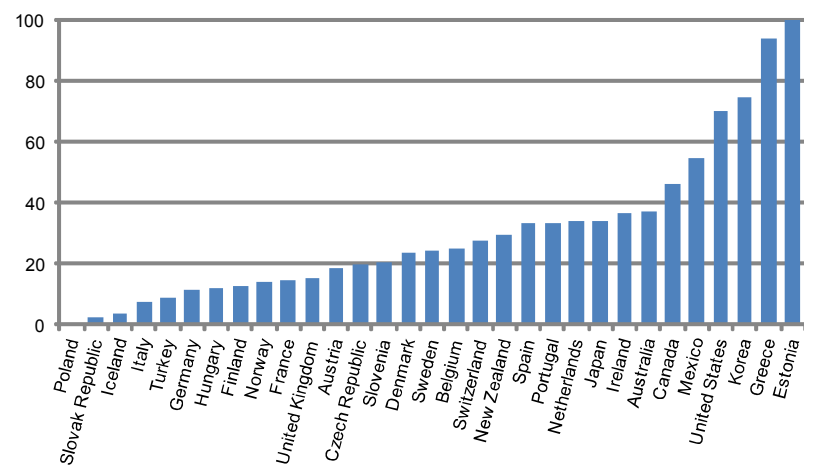

Note: Passenger and freight tonne kilometres are aggregated into a single variable using principal components analysis.

Source: International Transport Forum; World Bank Development Indicators; IRTAD; IEA, CO2 Emissions from Fuel Combustion (database); and IRF World Road Statistics 2011.

\section{Estimating the efficiency of the road transport sector and infrastructure}

The one-dimensional efficiency indicators, while useful, cannot capture the complexity of the production function of the road transport sector. Outputs are jointly determined, sharing the same physical infrastructure. Although multiple outputs could be combined into a single aggregate, this would require shadow prices for each of the outputs that are currently not available. Similar issues arise on the input side, where in addition complementarities and substitutability can be significant. Therefore, a comprehensive technical efficiency indicator needs to be based on a production function allowing for multiple inputs and outputs.

\subsection{The social efficiency of the road transport sector is low in some OECD countries}

Social efficiency is estimated using Data Envelopment Analysis (DEA). Appendix 2 discusses and compares the main methodological approaches used in efficiency studies: DEA and stochastic parametric frontier analysis. As shown in Appendix 3 (Table A3.2) DEA has already been used to study different efficiency aspects of the road transport sector, especially those relating to commercial transport. Available studies are heterogeneous in their aims and scope, but a common characteristic among recent analyses is the inclusion of undesirable outputs. This study differs from previous ones as it analyses the efficiency of the whole road transport sector, considering both passenger and freight traffic along with some undesirable outputs.

The framework developed in section 2 suggests that inputs should include road infrastructure, the vehicle fleet, fuel consumption and travel time. Desirable outputs should include passenger and freight traffic, and undesirable ones, such as injuries, emissions, congestion and travel time variability. As discussed in Appendix 1, travel time data are available only for a few countries, while data on travel time variability and congestion are not available. Emissions are also excluded from the DEA, as $\mathrm{CO}_{2}$ emissions are almost perfectly correlated with energy consumption. This leaves a baseline model with three inputs: the number of motor vehicles; the length of the road network (in kilometres); and energy consumption. 
Passenger and freight tonne-kilometres are proxies for transport volumes, whereas the number of injuries caused by road accidents is an undesirable output. ${ }^{7}$

Efficiency estimates are based on averaged data for the 2000s and adjusted for small-sample bias following the methodology of Simar and Wilson (1998). Appendix 2 provides details on the specific DEA model used. ${ }^{8}$ The length of the road network and the number of motor vehicles are treated as fixed factors as it is assumed that policy makers cannot change them in the short run. The efficiency scores reported below therefore reflect the proportional improvement in freight and passenger traffic, energy consumption and the number of injuries that could be achieved for a given size of the road network and vehicle fleet. Efficiency scores vary from zero (i.e. inefficient) to one (when the country lies on the efficiency frontier), where e.g. a score of 0.7 means that a country has the scope to lower energy consumption and the number of injuries by $30 \%$ and at the same time to increase passenger and freight traffic by the same percentage.

The baseline model shows efficiency being highest in France, Poland and Canada and lowest in Greece, the United States, Spain and Portugal (Figure 4.1). For many countries in the middle of the efficiency distribution, the ranking is inconclusive as the confidence intervals are wide. However, differences in efficiency between the best and worst performing countries are significant. For example, Greece could simultaneously reduce energy consumption and injuries and increase freight and passenger traffic by around $35 \%$. The respective numbers for the United States, Spain and Portugal are in the range of $20-25 \%$ and $10-15 \%$ for Sweden, the Czech Republic and Belgium. The potential improvements for Japan, Switzerland and Hungary are around $10 \%{ }^{9}$

\subsection{The results are robust to alternative model specifications and not driven by background factors}

The results are robust to changes in time periods and alternative scaling of the variables. Using data for the 1990s yields results similar to those above, suggesting that cross-country differences are persistent over time. Re-estimating the model with inputs and outputs scaled by population instead of GDP does not change efficiency estimates markedly, nor does using non-scaled variables, although some countries shift positions. When scaling variables by population, Luxembourg becomes the least efficient country, but little else changes. This probably reflects Luxembourg's high energy consumption per inhabitant due to cross-border fuel purchases by non-residents. ${ }^{10}$ The major change using non-scaled variables is that New Zealand and Canada become less efficient and the United States and Spain become more efficient. ${ }^{11}$

7. Injuries are modelled as an input in the DEA (alternative ways of modelling undesirable outputs are described in the Appendix 2). The number of road accidents was also used instead of the number of injuries, with virtually no change in results. For Austria, Iceland, Ireland, Luxembourg and New Zealand either passenger or freight traffic is missing throughout the 2000s. To avoid excluding these countries from the analysis, missing values were replaced by using the average ratio of freight to passenger traffic of the countries for which both sets of data are available. The high correlation between passenger and freight traffic lends support to this approach. The yearly correlation between these two variables ranges from 0.75 to 0.99 during the $2000 \mathrm{~s}$. As shown below, results are robust to excluding countries with replaced missing values from the analysis.

8. For all models, inputs and outputs are scaled by GDP (2005 PPP dollar). DEA with variable returns to scale was used.

9. Chile and Israel are not included due to lack of data on several inputs.

10. As many of these road users work in Luxembourg and contribute to local GDP, scaling by GDP is more relevant than scaling by population.

11. The correlation coefficient between the efficiency scores using variables scaled by GDP and non-scaled variables is 0.96 when Canada, New Zealand, Spain and the United States are excluded and 0.61 when they are included. 


\section{Efficiency}

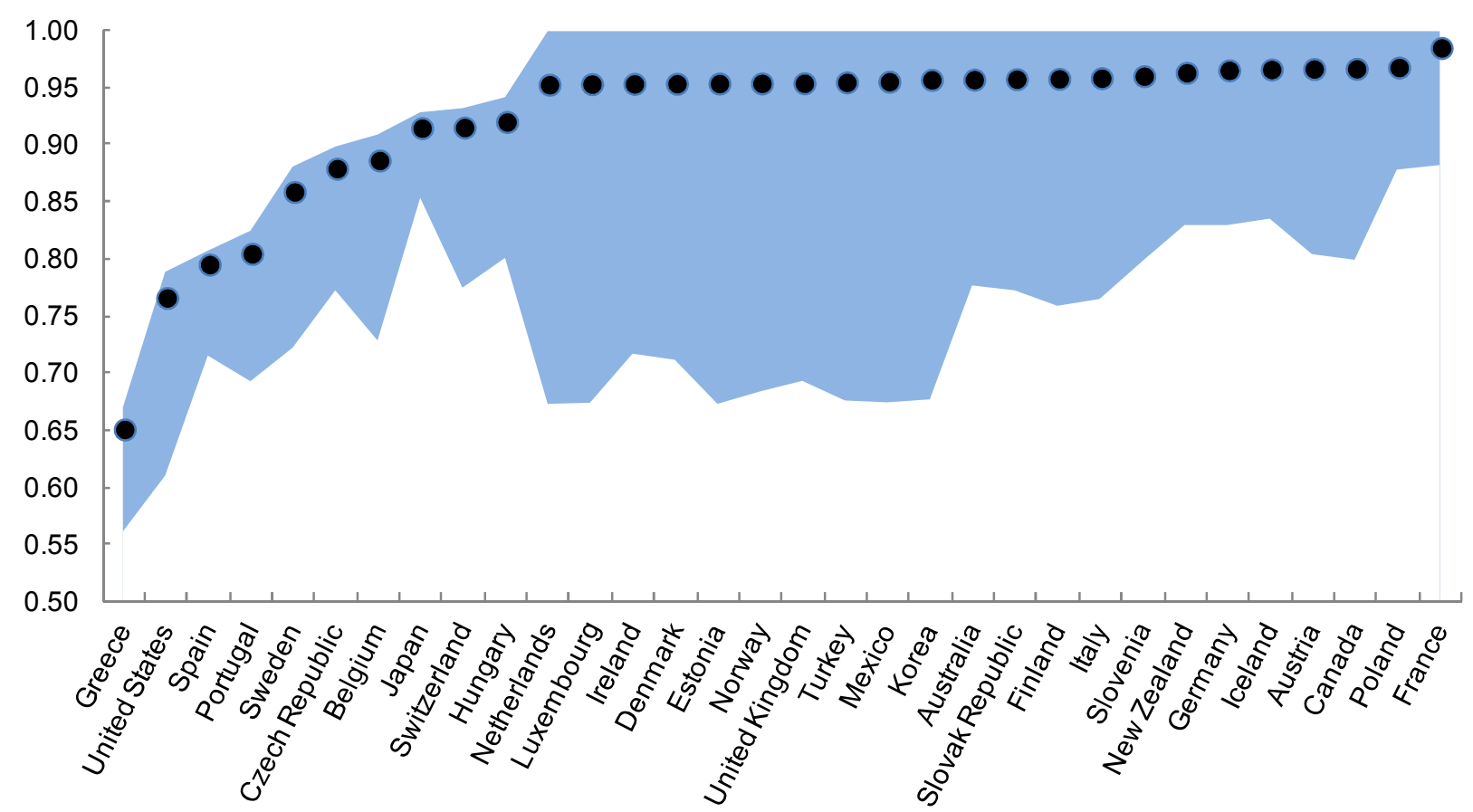

Note: Efficiency scores vary from zero (the lowest level of efficiency) to one (the highest). The shaded area represents the bootstrapped $95 \%$ confidence interval computed with the methodology by Simar and Wilson (1998). Inputs are the length of the road network, the number of motor vehicles and energy consumption. Desirable outputs are passenger and freight tonne kilometres, and injuries are an undesirable output. Data are averaged over the 2000s. All variables are scaled by GDP in 2005 PPP dollars.

Source: Authors' calculations.

The results are also robust to changes in input and output vectors. Although the estimated efficiency increases for all countries as the number of variables included in the model increases, the ranking of countries remains stable overall (Table A3.2). Adding $\mathrm{CO}_{2}$ emissions or substituting it for energy consumption does not alter the results either, because of the high correlation between the two variables.

Estimated efficiency scores are also robust to using alternative proxies for the road network. As discussed in Appendix 1, cross-country differences in the measurement of the road network can be large. Furthermore, the length of the motorway network may be a tighter constraint on transport capacity than the overall road network. Finally, unmeasured road quality differences and the need to spend on the network suggest that spending on road infrastructure could be a more relevant input.

Figure 4.2 shows the results of alternative efficiency estimates replacing the length of the road network with the length of the motorway network and road investment plus maintenance spending. ${ }^{12}$ Efficiency scores remain similar to those in the baseline estimate (the correlation with the baseline model is 0.94 using investment and maintenance data and 0.98 using the length of the motorway network). Efficiency levels for Japan and Switzerland drop by more than 7\%, however, when using investment and maintenance expenditure. This likely reflects high construction costs stemming from the challenging topography in these countries (Box 4.1) and large infrastructure spending undertaken in Japan in the last

12. Investment and maintenance data have been averaged over the 1990s and 2000s. 
two decades. Belgium, Switzerland, the United Kingdom and Germany experience a noticeable but not dramatic decrease in efficiency - between around 4 and $8 \%$ - when the length of the motorway network is used.

Figure 4.2. DEA efficiency scores are broadly unchanged using alternative road network proxies

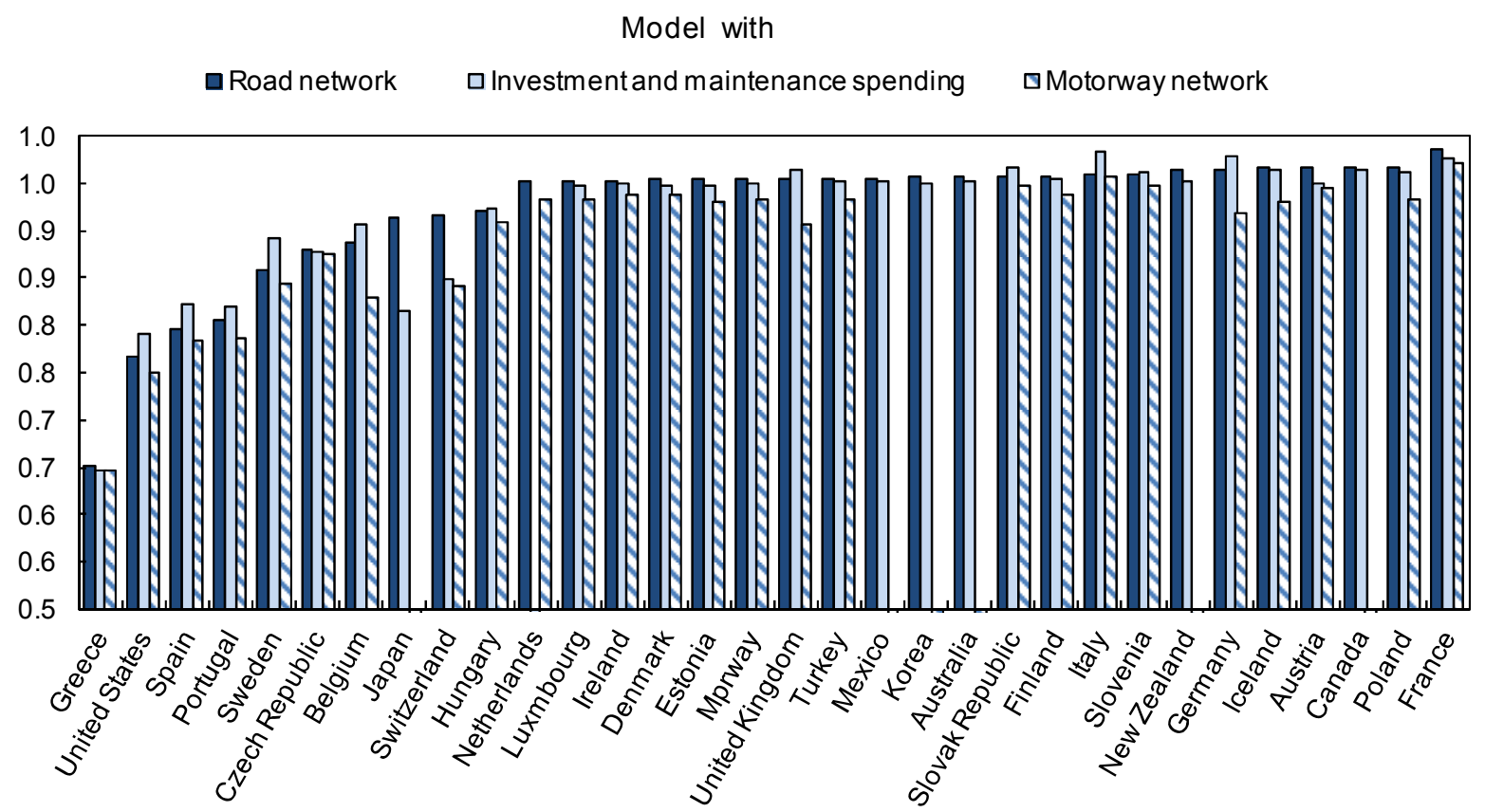

Note: Efficiency scores obtained using the baseline model (Figure 4.1) with alternative road network measures. Investment and maintenance spending is scaled by nominal GDP and averaged over the 1990s and 2000s. Efficiency scores vary from zero (the lowest level of efficiency) to one (the highest). Countries are ordered by the efficiency score obtained using the length of the road network.

Source: Authors' calculations.

The results are also robust to additional changes:

- Adding travel time. As shown in Table 2.1, time is a major cost component in the road transport sector. To reflect this, travel time was added to the baseline DEA model (Figure 4.1) as an additional input. Two sources of information on travel time were used:

- Household surveys: These travel time data are available only for 12 countries (Belgium, Estonia, Finland, Germany, Hungary, Italy, Norway, Poland, Slovenia, Sweden, Spain and the United Kingdom). They provide information on how much time individuals spend travelling by road, excluding public transport and bicycling. Travel times reflect travel speed - including congestion - but also depend on other factors such as residential patterns. The baseline DEA was re-estimated for this subset of countries and the results compared with a specification including travel time. The results of the two models are virtually identical. The only exception is Spain where the efficiency score increases substantially when travel time is considered.

- A standardised travel time measure based on the methodology described in Box 3.1: A theoretical travel time index is constructed by inverting the distance and population weighted connectivity index. When adding this variable, the main change in the efficiency estimates compared to the baseline model concerns Spain and Japan, as their efficiency score rises markedly. This reflects their favourable performance in terms of connectivity compared with 
other OECD countries (Figure 3.1). Efficiency measured with and without standardised travel time is highly correlated however, the correlation coefficient being 0.96 .

- Excluding from the analysis those countries that do not report either passenger or freight traffic figures for the 2000s. The model was re-estimated without Austria, Iceland, Ireland, Luxembourg and New Zealand as either passenger or freight traffic figures are missing for these countries for the 2000s. The correlation coefficient between these efficiency scores and those of the baseline model (shown in Table 4.1) is 0.97. The largest change in country ranking concerns Hungary, which becomes one of the most efficient countries.

- Splitting total motor vehicles into passenger and goods vehicles. As passenger and freight traffic are separate outputs, the motor vehicle variable was split into passenger and goods vehicles. These data are not available for Estonia and Mexico. The correlation coefficient between these efficiency scores and those of the baseline model is 0.88. Efficiency in the United States improves markedly - improving its ranking to the middle of the sample - as the input of passenger vehicles becomes low due to the use of light trucks, which are classified as goods vehicles, for passenger transport. ${ }^{13}$

- Background factors such as geography and alternative transport modes do not have a major impact on efficiency estimates. As argued in section 2, efficiency scores may be affected by background factors beyond the realm of road transport policies. As shown in Box 4.1, there is little evidence that either internal distance within countries, topographical features or alternative transport modes such as the rail network explain significant cross-country differences in efficiency scores.

Efficiency scores were also estimated by parametric frontier methods using the Corrected Ordinary Least Square (COLS) methodology. These estimates are shown in Appendix 3 (Table A3.3). The correlation coefficients between DEA and parametric frontier efficiency scores are positive but not high (Table A3.4). As argued in the appendix, endogeneity problems and other issues render DEA estimates preferable to COLS.

\subsection{Some countries show large scope for efficiency gains}

The efficiency scores shown in Figure 4.1 are calculated considering simultaneous changes in all discretionary variables. However, countries may not have effective instruments to bring about change in all dimensions. In addition, road transport systems might be close to the frontier in some dimensions, e.g. energy efficiency, while being far from it in some others, e.g. passenger kilometres.

13. The United States has the lowest share of passenger vehicles in the total number of vehicles in the OECD area at $57 \%$, compared to an OECD average around $85 \%$. 


\section{Box 4.1. The effect of geographic factors and other modes of transport is limited}

As discussed in section 2, road transport costs may be affected by geographic factors and the supply and quality of other modes of transport. They can affect transport outcomes and inputs through several channels (Figure 2.3). A country with a high geographic concentration of economic activity, as measured by internal distance (Antweiler, 2008), will face lower transport costs for a given set of private and public inputs. Providing countries characterised by dispersed populations with high-quality road infrastructure is likely to be expensive, due to increasing economies of scale in road capacity provision related to minimum scale requirements of roads (Quinet and Vickerman, 2004). However, as economic concentration increases construction costs will rise due to higher land prices ( $\mathrm{Ng}$ and Small, 2008), likely producing a u-shaped relationship between the cost of infrastructure provision and economic density. Geographic concentration means shorter average distances, faster trips and lower fuel and vehicle cost, but also makes other transport modes (walking, biking, public transport) more attractive. It is thus likely that trip costs are lower in more geographically concentrated economies leading to more - but shorter trips. Transport volumes may, however, be larger in dispersed economies, as longer trip distances likely dominate lower trip volumes, at least for freight transport.

Topography is also likely to influence outcomes and inputs. Construction costs are e.g. up to 4.5 times higher in mountainous than in flat regions (Nash et al., 2008), likely leading to smaller, costlier and less connected networks. $^{2}$ Trip costs also rise, with slower speeds and higher fuel consumption. Negative environmental externalities due to noise, loss of natural beauty and lower regeneration capacity of biotopes also tend to be larger in those regions (Nash, 2003). Internal distance and topographic conditions vary substantially across OECD countries (Figure 4.3).

Figure 4.3 Roughness of topography and internal distance Topography

Internal distance
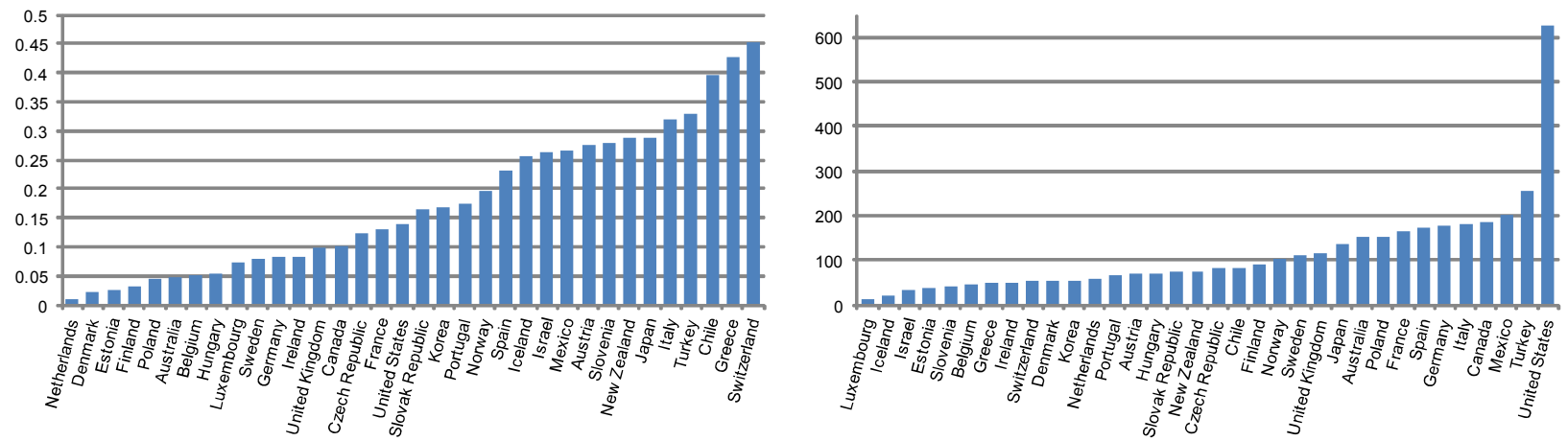

Note: Topographic roughness is low for flat countries and high for mountainous ones. It is calculated using grid cell data for each country sourced from Gridded Population of the World database (CIESIN, 2005) as the weighted average of the difference in elevation between adjacent cells, with weights proportional to the size of cells. Internal distance gauges the geographic concentration of economic activity in each country and declines with the level of concentration. This index was computed by Antweiler (2008) using data from Gridded Population of the World database (CIESIN, 2005) as the weighted average of the distance among all cells within a country, with weights proportional to the cells' population.

It is neither possible nor desirable for policy makers to compensate fully for economic disadvantages related to background factors. High transport costs due to long distances or a difficult topography are real costs that investment in infrastructure may mitigate but not remove. Thus, countries where distances are long and topography is challenging may optimally spend more resources on infrastructure, but are still likely to provide lower connectivity at higher trip costs and hence lower traffic flows than better endowed countries.

The availability and accessibility of alternative modes of transport in the form of rail, air and sea transport also affect road transport outcomes and are clearly relevant for transport planning. From the road user perspective these alternative modes are taken as given, even though alternative modes of transport can substitute for road transport services and therefore decrease demand for road infrastructure. However, especially for transit countries, providing e.g. port facilities could increase demand for road transport to these facilities. As seen in Figure 4.4, the modal mix varies across OECD countries. The relative importance of rail in Canada and the United States, where travel distances are often long, stands out.

Figure 4.4. Modal split of inland freight transport 


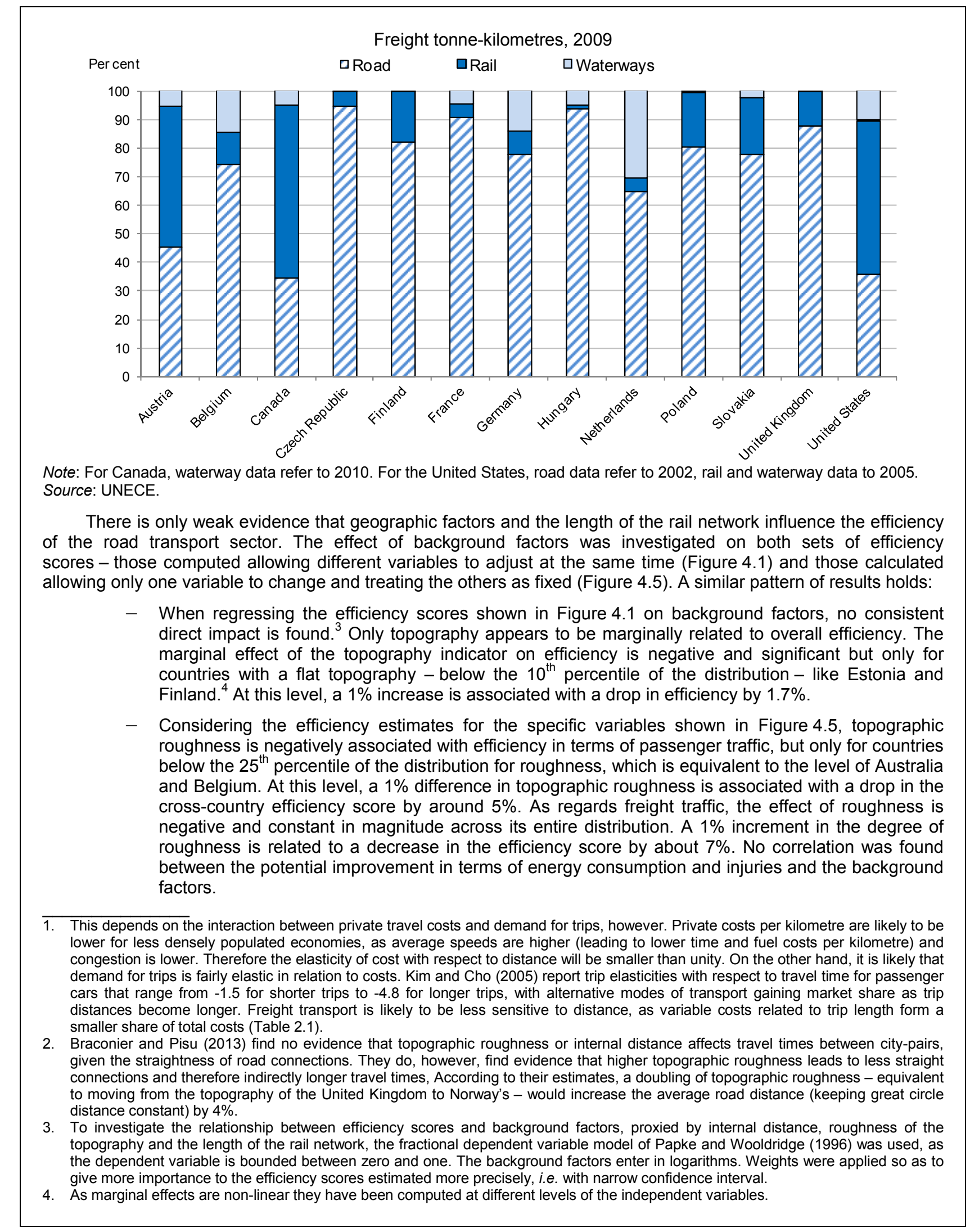


Efficiency scores were computed gauging the potential improvements in each of the inputs and outputs, separately. They measure the potential improvement in passenger or freight traffic or the number of injuries or energy consumption, assuming all the other variables remain unchanged. Once again, the indices vary from zero (the lowest efficiency level) to one (on the frontier).

Figure 4.5 shows these efficiency indices. The main results are:

- Potential increases in passenger traffic are highest in Greece. The point estimate suggests that passenger traffic is only $40 \%$ of what could be achieved keeping other outputs and inputs constant. Japan and Spain also show large potential for increases in passenger traffic, with output at only $70 \%$ of what could be achieved. France, Austria and Canada are the countries closest to the frontier in this dimension.

- Greece is also underperforming in terms of freight traffic volumes, with the output level only $30 \%$ of what could be achieved by moving to the frontier. Portugal and Switzerland also perform poorly, with a freight traffic level that is less than $50 \%$ of what could be achieved on the frontier. Germany and Estonia show the best performance, although confidence intervals are large for these countries.

- Japan, the United States, Greece and Belgium have the largest scope to reduce injuries caused by road accidents. In these countries injuries could be reduced by more than $80 \%$, for the same level of the other outputs and inputs. Other countries with a sizeable room to lower injuries are Portugal, Hungary, Switzerland, Spain and Sweden. For the other countries, differences in the efficiency scores are small and confidence intervals too large to rank them.

- In terms of energy consumption, the United States has the largest room for improvement, followed by Greece and Spain. The United States has the potential to more than halve energy consumption without changing volumes of outputs or other inputs, whereas for Greece and Spain the potential reduction is around $35 \%$. At the other end of the distribution, France has the highest efficiency score, with a reasonably small confidence interval. 
ECO/WKP(2013)8

\section{Figure 4.5. DEA efficiency scores with respect to specific variables}
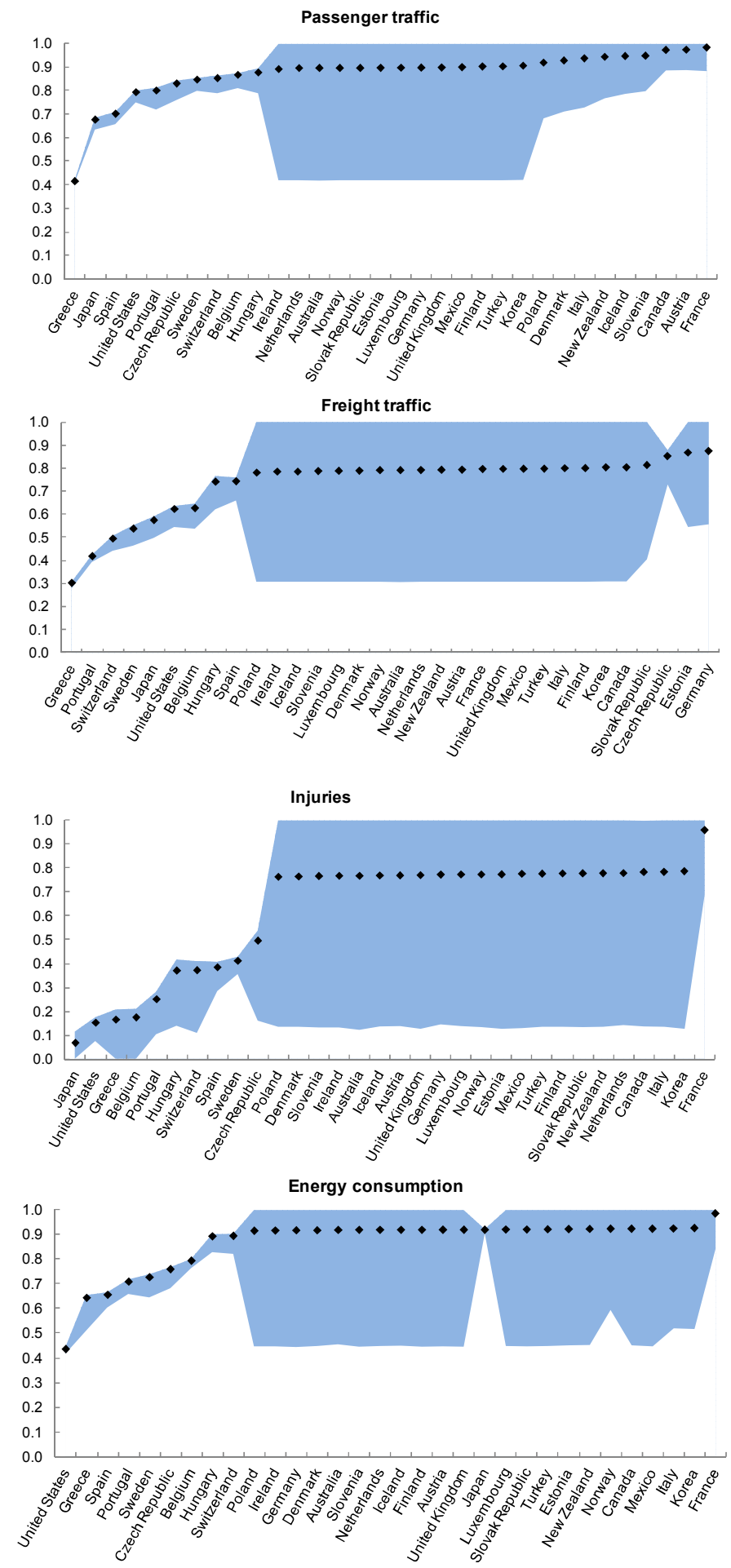

Note: Efficiency scores vary from zero (lowest level of efficiency) to one (the highest). The shaded area represents the bootstrapped 95\% confidence interval computed with the methodology by Simar and Wilson (1998). Inputs and outputs are the same as in Figure 4.1. Efficiency scores reflect the potential improvement in the variable considered assuming all other variables are kept at their baseline level. For inputs and undesirable outputs, an efficiency score of 0.7 means that there is room to reduce them by $30 \%$. For outputs, the same efficiency score means that the output level is $70 \%$ of what could be achieved by moving to the frontier.

Source: Authors' calculations. 
Overall, potential efficiency gains are positively correlated, suggesting that countries' room for improvement in one dimension is correlated with room for improvement in other dimensions, although there are exceptions (Table 4.1). For instance, Japan is close to the frontier in terms of energy consumption but at the same time shows a large potential for improvement in terms of passenger traffic and injuries.

Table 4.1. Potential improvements in separate dimensions are positively correlated

\begin{tabular}{lc|c|c|c|c}
\hline & \multicolumn{3}{c|}{ Input or output efficiency } & \multicolumn{1}{c}{$\begin{array}{c}\text { Input-output } \\
\text { efficiency }\end{array}$} \\
\cline { 2 - 5 } & $\begin{array}{c}\text { Energy } \\
(1)\end{array}$ & $\begin{array}{c}\text { Injuries } \\
(2)\end{array}$ & $\begin{array}{c}\text { Passengers } \\
(3)\end{array}$ & $\begin{array}{c}\text { Freight } \\
(4)\end{array}$ & $(5)$ \\
\cline { 2 - 5 } Energy & 1.00 & 0.85 & 0.68 & 0.64 & 0.65 \\
Injuries & & 1.00 & 0.70 & 0.78 & 0.68 \\
Passengers & & 1.00 & 0.53 & 0.91 \\
Freight & & & 1.00 & 0.94 \\
Input-output efficiency & & & & & 1.00 \\
\hline
\end{tabular}

Note: The figures show the rank correlation coefficients between input or output oriented efficiency scores (columns one to four) shown in Figure 4.4 and the input-output oriented ones (column 5 ) shown in Figure 4.1.

Source: Authors' calculations.

Figure 4.6 shows the efficiency score measured in terms of the length of the road network and number of motor vehicles in circulation. The size of the road network and the stock of vehicles have so far been treated as fixed factors, as they change only slowly. Policies and economic forces can affect the length and quality of the road network and the stock of motor vehicles in the long run, however. Current investment and maintenance choices affect the size and quality of the future road network. Taxes and regulation influence the quantity and types of motor vehicles in circulation. Also, changing economic needs due to agglomeration economies, demography and the emergence of new technologies - enabling people to reduce the number and/or length of trips - will raise the need to adjust road networks. To gauge countries' long-run potential for reducing road networks and vehicle fleets, these inputs are therefore allowed to adjust keeping outputs and other inputs constant. ${ }^{14}$

As regards the road network, Sweden, Hungary and Greece have the lowest efficiency score, meaning that these countries have the largest room for reducing its length while keeping the other outputs and inputs at their current level. Other countries that appear to have overextended road networks - with reasonably narrow confidence intervals - are the United States, Spain, Portugal, Belgium, the Czech Republic, Switzerland and Japan. Taken at face value, Sweden should be able to produce the same transport outcomes with just $15 \%$ of the road network if it moved to the efficient frontier. The upshot of these results is that for some countries the road network is not a binding constraint on transport output and hence is inefficiently large.

14. This does not take into account the distributional aspects of car and road network access. The latter is often part of regional policy objectives and forms the rationale for providing adequate road network access in rural areas. 
Figure 4.6. DEA efficiency scores with respect to the road network and motor vehicles
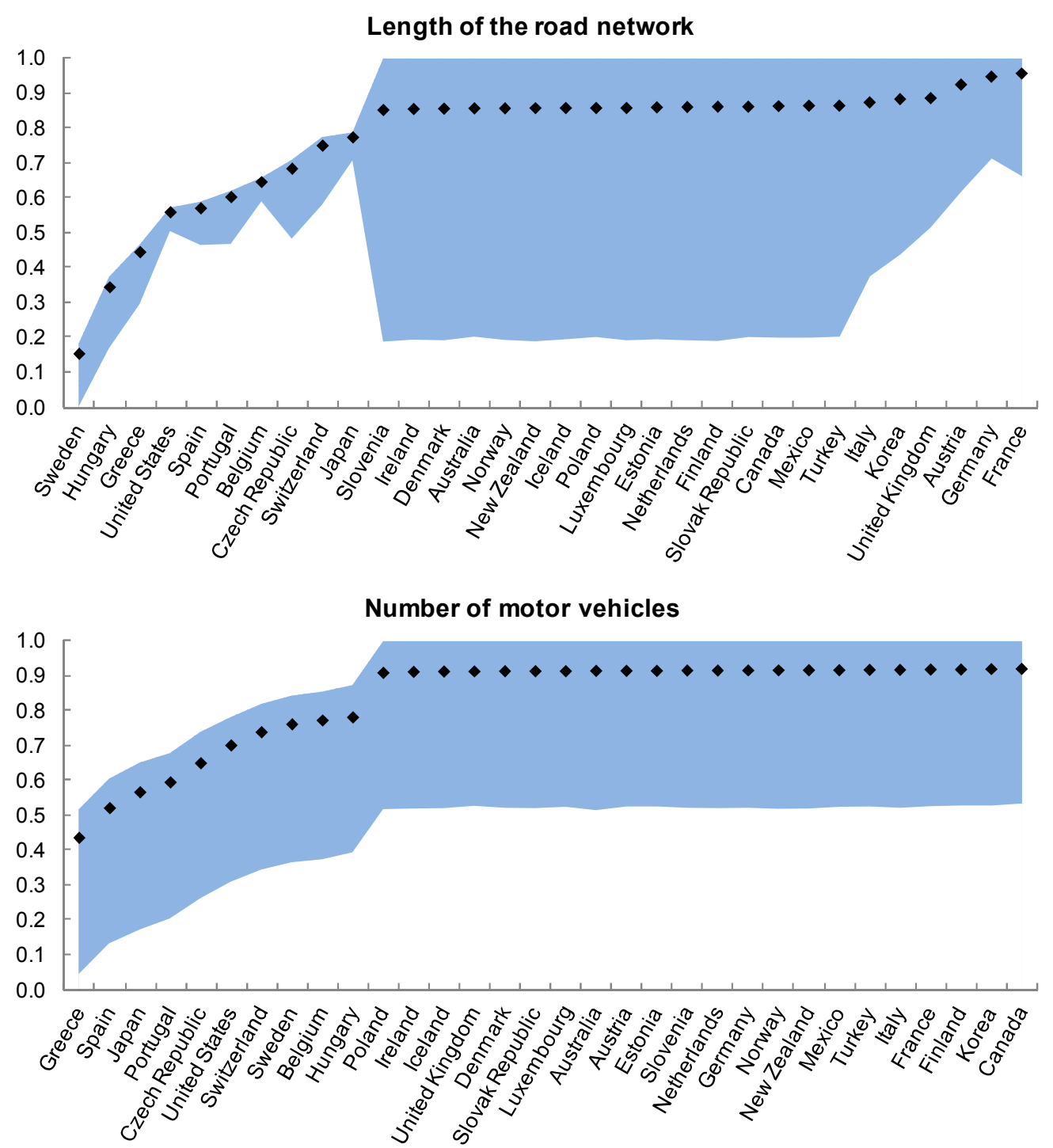

Note: Efficiency scores vary from zero (lowest level of efficiency) to one (the highest). The shaded area represents the bootstrapped 95\% confidence interval computed with the methodology by Simar and Wilson (1998). Efficiency scores reflect the potential improvement in the variable considered assuming all the others are kept at their current level. An efficiency score of 0.7 means that there is room to reduce the length of the road network or the number of motor vehicles by $30 \%$.

Source: Authors' calculations.

The extremely low performance of Sweden with respect to the length of the road network is partly related to data issues. According to the World Bank data used in the empirical analysis, Sweden's road network is around 575000 kilometres long. However, data for 2010 from the Swedish Transport Administration indicate a length of the road network of about 220800 kilometres. The large difference is due to the fact that the Swedish Transport Administration does not consider roads classified as "forest roads", as they do not receive state subsidies and public access is limited (Trafikverket, 2010). The efficiency of the Swedish road transport sector was therefore reassessed using the data from the Swedish Transport Administration. The new set of estimates are virtually identical to the one based on the original data. There is no change in country ranking and very minor changes in efficiency scores and their confidence intervals. The only noticeable change concerns Sweden's potential reduction of the length of 
the road network, which is now similar to Hungary's in Figure 4.5. Overall, this suggests that different road classifications for the least efficient countries may affect efficiency scores but do not qualitatively change the results.

The countries with low efficiency scores in terms of the road network also tend to have the largest room to reduce the stock of motor vehicles. Point estimates suggest that the number of motor vehicles could be reduced by between 40 and $60 \%$ in Greece, Spain, Japan and Portugal. ${ }^{15}$

\subsection{Savings arising from potential efficiency gains are considerable}

Combining the efficiency estimates with relevant prices makes it possible to calculate potential improvements in social welfare by moving to the frontier. These savings were first calculated for the reduction in investment and maintenance expenditure and then for energy consumption, assuming all the other inputs and outputs are fixed. Calculating savings in terms of investment and maintenance does not require price information as this variable is already expressed in value terms. The lower costs associated with reduced energy consumption are computed by taking the potential decline in energy consumption and multiplying it by the corresponding energy price in $2011 .{ }^{16}$ Confidence intervals for potential savings are based on the confidence intervals of the corresponding efficiency scores.

Potential welfare gains in terms of reduced investment and maintenance spending by adopting best practice are large (Figure 4.7). Cost savings as a share of GDP are larger for those countries that have a low efficiency score and spend a lot on investment and maintenance. Savings are computed considering the 2000s average investment and maintenance spending-to-GDP ratio. Japan stands to gain the most from reducing investment and maintenance expenditure by moving to the frontier, with potential savings around $2 \%$ of GDP, which is close to current levels of spending. ${ }^{17}$ For Switzerland, Portugal and the Czech Republic potential savings are between 0.7 and $1.0 \%$ of GDP, whereas they are around $0.5 \%$ for Hungary, Spain, Greece and the United States. The potential to lower investment and maintenance expenditure is smallest in Korea, mainly due to its already low level of spending, and Germany. ${ }^{18}$

15. It may be argued that a larger (passenger) fleet may provide better services, in terms of connectivity and trips, than a smaller fleet. However, there are likely diminishing returns to car ownership both on the household and societal level. A large passenger vehicle fleet could also provide more equitable access to passenger car services. European data on "enforced lack of personal car" (Eurostat SILC, 2012) - measured as the share of households that need a car but can't afford it - does not support this, as it shows high levels of car deprivation in "car-rich" countries as Greece, Spain, Portugal, the Czech Republic and Hungary.

16. Energy consumption and the potential reduction are expressed in kilotons of oil equivalent. The price used is the kiloton oil equivalent energy price, net of taxes, for 2011 (the latest available year).

17. Japan's potential saving in terms of investment and maintenance reflects its extremely low efficiency score in this dimension (0.04). Over the 1990s and 2000s, Japan's investment and maintenance spending as a share of GDP was indeed the highest among the OECD countries included in the DEA analysis $(2.8 \%$ per year, on average, against an OECD mean of 0.98). DEA efficiency scores suggest that such a high level of spending for Japan has not translated into better road transport output measures or lower usages of the other inputs, as compared to other OECD countries. Japan seems to have already reduced its investment and maintenance spending, as its yearly average for the 2000 s was $2.3 \%$ of GDP.

18. The expected investment and maintenance savings for Sweden are modest compared to what could be inferred by looking at the potential improvement in terms of road network's length (Figure 4.6). This is because, although having an extensive road network, Sweden compares favourably in investment and maintenance spending. 
Potential welfare gains in terms of lower energy use are of similar size as those for investment and maintenance spending (Figure 4.7). Potential gains range from close to zero for France to around 1\% of GDP for Spain, Portugal and Greece, and 2.5\% of GDP for the United States. It should be noted that the estimated savings in investment or energy consumption do not consider potential losses in consumer surplus that could be related to lower road and vehicle quality. For instance, downsizing the US vehicle fleet by reducing the share of SUVs could be one of the easiest ways to reduce energy use in the United States. However, as long as buying SUVs reveals consumers' preferences for larger and heavier vehicles, any shift from such vehicles towards smaller and more energy efficient ones will involve some loss in consumers' surplus.

Figure 4.7. Potential savings from reducing investment and maintenance and energy consumption

Percentage of GDP

\section{Saving in investment and maintenance}

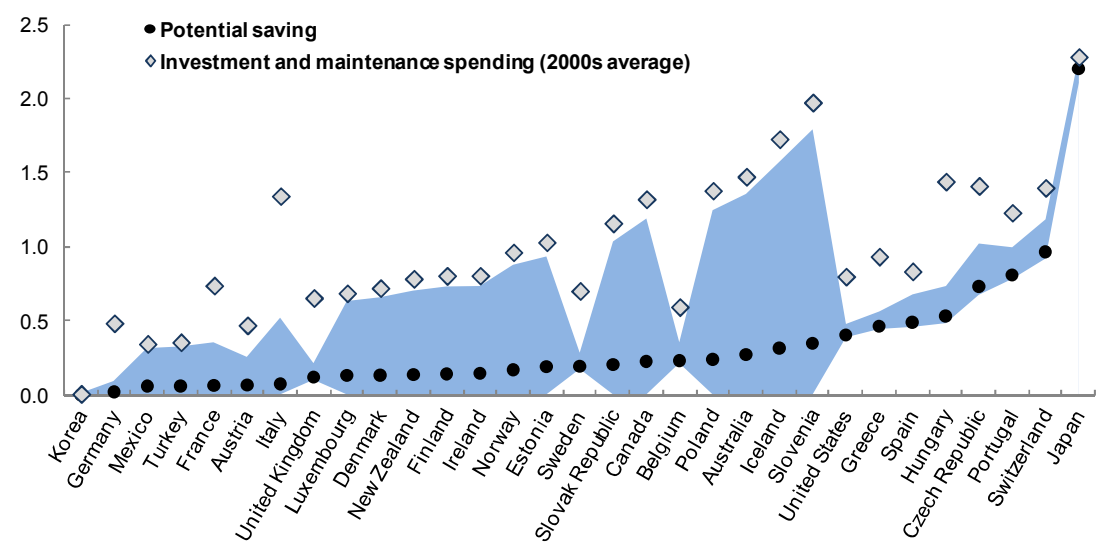

Saving in energy consumption

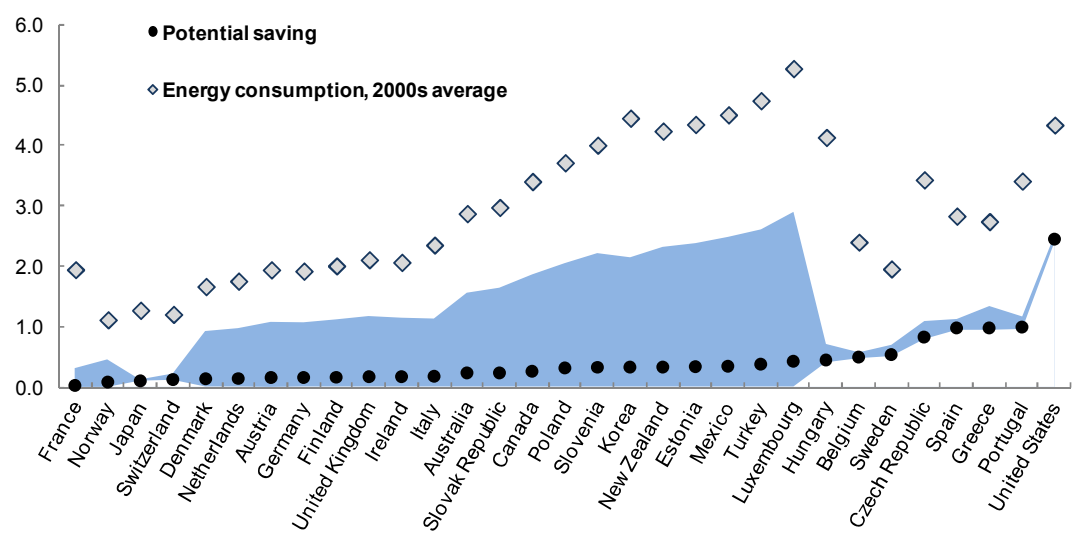

Note: Savings are based on the efficiency scores assuming all efficiency gains are realised by reducing one input only - i.e. treating all the other inputs and outputs as fixed. The average of the investment and maintenance spending-to-GDP ratio over the 2000s of each country is multiplied by one minus the corresponding efficiency index to obtain the potential saving shown in the figure. The shaded area represents the $95 \%$ confidence intervals. Savings deriving from lower energy consumption are computed based on the reduction in energy consumption expressed in kilotons of oil equivalent derived from the efficiency scores in Figure 4.5 and multiplying it by the kiloton oil equivalent average price - net of taxes - of automotive diesel and premium unleaded 95 RON fuel for 2011. Savings in local currency are divided by the 2001-08 average nominal GDP in local currency as efficiency estimates are based on average 2001-08 data. Energy consumption savings for Iceland are missing as energy prices are not available for this country.

Source: IEA and authors' calculations. 
Energy use in the road transport sector creates additional social costs, primarily in terms of $\mathrm{CO}_{2}$ emissions, which induce climate change. These costs may be gauged using an estimate of the shadow cost of $\mathrm{CO}_{2}$ emissions. Such estimates are highly uncertain however, with the US National Research Council (2009) estimating the social cost of carbon emissions between USD 1 and 100 per tonne of $\mathrm{CO}_{2}$. OECD (2012) analyses the least costly strategies for climate change abatement and puts abatement costs in 2050 in the range of USD 40 to 530 per tonne of $\mathrm{CO}_{2}$ depending on the target level of greenhouse gas concentrations. For illustrative purposes, a conservative shadow cost equal to EUR 22 is assumed (Nash et al., 2008). Based on the assumed shadow price costs, expressed as percentage of GDP, are small with respect the potential saving generated by lower energy consumption (Figure 4.8).

\section{Figure 4.8. Potential savings from reducing $\mathrm{CO}_{2}$ emissions}

Percentage of GDP

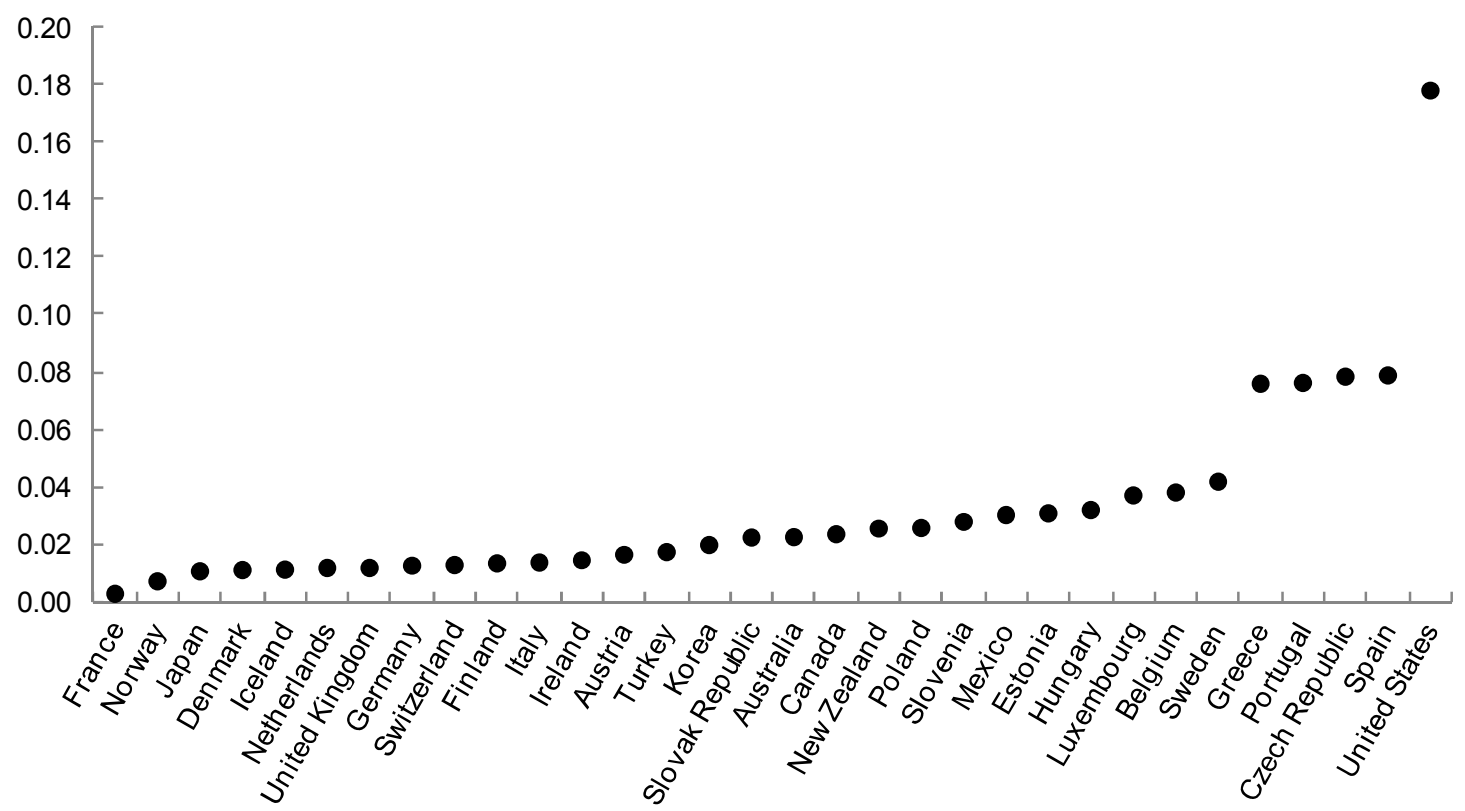

Note: Savings deriving from lower $\mathrm{CO}_{2}$ emissions are computed based on the reduction in energy consumption expressed in kilotons of oil equivalent derived from the efficiency scores in Figure 4.5 and multiplying it by the kiloton oil equivalent average price - net of taxes - of automotive diesel and premium unleaded $95 \mathrm{RON}$ fuel for $2011 . \mathrm{CO}_{2}$ emissions are assumed to decrease in the same proportion as energy consumption. The price per tonne of $\mathrm{CO}_{2}$ used is EUR 22.

\subsection{Input-output elasticities are not precisely estimated}

DEA produces reliable efficiency estimates, but it does not provide estimates of input-output elasticities. To investigate these relationships multi-output production functions were estimated. ${ }^{19}$ Each output (i.e. passenger traffic, freight traffic and injuries) was regressed on all inputs (i.e. energy consumption and the length of the road network), while also controlling for all the other outputs. In addition, energy consumption and the length of the road network were regressed on each other and all outputs. ${ }^{20}$ The regressions also include the background factors (internal distance, roughness and the length

19. Production functions differ from the parametric frontiers that were estimated by COLS (Appendix 2). The latter provide efficiency estimates, whereas the former estimates input-output elasticities. In a single output model, the residual of a production function can be interpreted as a productivity measure but not in a multi-output production setting.

20. These regressions can be interpreted as input demand functions. 
of the rail network). ${ }^{21}$ These regressions yielded only a few statistically significant elasticities (Appendix 3 , Table A3.5). The most salient ones are: passenger and freight traffic are positively associated with energy consumption; passenger traffic and energy consumption are also positively related to the number of motor vehicles, whereas there is a negative relationship between length of the road network and energy consumption. Internal distance, the roughness index and the extent of the rail network do not seem to exert any effect on the variables considered.

\section{A framework for linking road transport performance and policy}

The empirical analysis shows cross-country differences in efficiency, suggesting a role for policy settings in determining road transport efficiency. In some areas, such as fuel efficiency, links between policies and outcomes are relatively well established (Small and van Dender, 2007; Schmitz, 2012). In other areas, the effect of policies on outcomes is less clear and cross-country policy indicators are not available. In order to analyse the linkages between policies and performance, a policy framework is developed. Due to lack of data on cross-country policy settings, it is, however, not possible at the current juncture to empirically analyse the impact of policy on road transport efficiency.

Policy can influence outcomes directly or through the quantity and quality of inputs, which in turn affect outcomes (Figure 5.1). This fits into the analytical framework of analysing social efficiency (section 2), where the infrastructure network and user inputs interact to produce desirable and undesirable outcomes (Figure 2.3). The policy settings that could affect road infrastructure performance are classified along two dimensions: $i$ ) what specific inputs and outcomes are affected and how; and $i$ ) the degree of concreteness of policy design, ranging from general framework conditions to the use of specific instruments.

As regards the first policy dimension, three channels can be indentified:

- Road network configuration and management-e.g. how policies affect the size, geographic distribution and configuration of the road network. Well designed and well managed networks should provide good and reliable access for households and firms, with new projects providing positive net social benefits and also greater cost-effectiveness than other options for providing mobility.

- $\quad$ Regulation and management of user inputs, representing policies that affect the vehicle fleet, fuel and time. Examples are vehicle and fuel taxation, working-time rules for drivers and safety and emission standards. Such policies should aim at ensuring that vehicle ownership costs and regulation and the pricing of vehicle fleet characteristics are aligned with social costs, for example, in terms of user surplus, pollution and accident costs.

- Management of road use - e.g. ensuring that public and user inputs interact efficiently to produce transport services; examples are toll roads, flexible lanes, congestion charges, drink and drive policies and restrictions in time or space of providing specific transport services.

In the second dimension, transport policy settings are classified according to the design challenges that policy makers face. These challenges concern the different actors within the government and their coordination, the role of the private sector and the use of regulatory versus price based instruments.

21. Data from 2001 onwards were used with the variables scaled by GDP in USD 2005 PPP and in logarithms. As geographic variables do not vary over time, the random-effects panel data model was used instead of the fixed-effects panel data model. Because of missing values, the estimation relied on 159 observations. A full set of time fixed effects was included. To reduce endogeneity, each equation was estimated separately. Standard errors are clustered by country to take into account the intra-country correlation of the error term. 
Together these two dimensions yield a classification of policy settings and how they may affect social efficiency (Table 5.1).

Figure 5.1. The policy framework

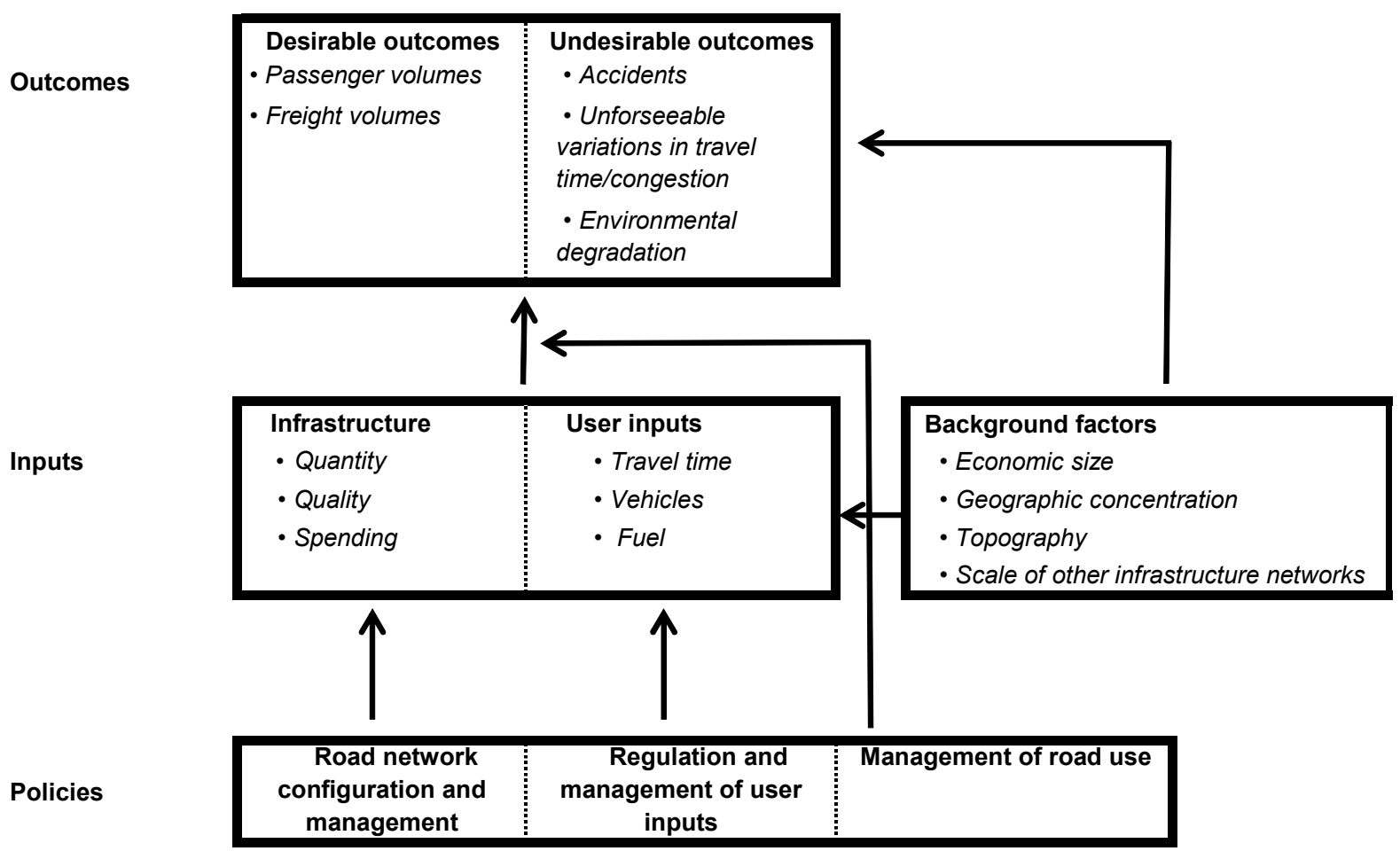

\subsection{The efficiency of national institutions}

Whether responsibilities for planning, constructing and maintaining public roads rests within a government ministry or an independent transport agency, they compete for government resources with other spending areas. This provides incentives for showing high ex ante benefit-cost ratios for new projects, likely contributing to the failure of many infrastructure projects to deliver expected benefit-cost ratios. Flyvbjerg (2009) reports that average cost overruns in a large international sample of construction projects were $20.4 \%$ for roads, $33.8 \%$ for bridges and tunnels and $44.7 \%$ for rail. Nor has there been any tendency for cost overruns to decline over time. Mechanisms that promote realistic planning in terms of benefits and costs can therefore be valuable. This also applies to maintenance spending, as shrinking user demand, e.g. due to a declining population, may push user benefits below maintenance costs, raising the issue of downgrading road quality or decommissioning. High-quality independent ex ante evaluations and realistic forecast methods could mitigate optimism-bias. Independent auditing expost, as currently practiced e.g. in France and the United Kingdom, may also be useful from this perspective (Persson and Song, 2010). 
Table 5.1. Examples of policy challenges in designing road transport policies

\begin{tabular}{|c|c|c|c|}
\hline & $\begin{array}{l}\text { Road network configuration } \\
\text { and management }\end{array}$ & $\begin{array}{c}\text { Regulation and } \\
\text { management of user inputs }\end{array}$ & $\begin{array}{l}\text { Management of } \\
\text { road use }\end{array}$ \\
\hline $\begin{array}{l}\text { Effectiveness of national } \\
\text { institutions }\end{array}$ & $\begin{array}{l}\text { - Incentives for interaction } \\
\text { with other network } \\
\text { administrators } \\
\text { - The use of ex ante and } \\
\text { ex post evaluations } \\
\text { - Independence of evaluations }\end{array}$ & $\begin{array}{l}\text { - Regulatory impact } \\
\text { assessment }\end{array}$ & $\begin{array}{l}\text { - Adequacy of } \\
\text { maintenance } \\
\text { spending }\end{array}$ \\
\hline Degree of decentralisation & $\begin{array}{l}\text { - Local government role in } \\
\text { planning process } \\
\text { - Local government incentives } \\
\text { for information sharing in } \\
\text { planning and development } \\
\text { processes }\end{array}$ & - & $\begin{array}{l}\text { - Local government } \\
\text { involvement in } \\
\text { management of } \\
\text { roads }\end{array}$ \\
\hline $\begin{array}{l}\text { The role of the private } \\
\text { sector }\end{array}$ & $\begin{array}{l}\text { - Designing efficient } \\
\text { procurement and PPPs }\end{array}$ & - & $\begin{array}{l}\text { - Contracting of PPPs } \\
\text { and service contracts }\end{array}$ \\
\hline $\begin{array}{l}\text { The use of regulatory } \\
\text { instruments }\end{array}$ & $\begin{array}{l}\text { - Entry regulation and } \\
\text { competition in management, } \\
\text { financing and construction of } \\
\text { roads }\end{array}$ & $\begin{array}{l}\text { - Safety standards } \\
\text { - Fuel economy standards } \\
\text { - Entry regulation and } \\
\text { price controls in road } \\
\text { freight sector }\end{array}$ & $\begin{array}{l}\text { - Restrictions on } \\
\text { freight traffic in time } \\
\text { and space } \\
\text { - HOV lanes }\end{array}$ \\
\hline $\begin{array}{l}\text { The use of economic } \\
\text { incentives }\end{array}$ & $\begin{array}{l}\text { - Cost, benefit and risk } \\
\text { sharing with local } \\
\text { stakeholders and private } \\
\text { sector }\end{array}$ & $\begin{array}{l}\text { - Registration taxes } \\
\text { - Recurrent vehicle taxes } \\
\text { - Fuel taxes } \\
\text { - Accident risk-adjusted } \\
\text { taxes on vehicles and } \\
\text { insurance }\end{array}$ & $\begin{array}{l}\text { - Congestion charges } \\
\text { and tolls }\end{array}$ \\
\hline
\end{tabular}

Top-down budgeting can help contain spending growth but leads to competition for funding between agencies responsible for different modes of transport, possibly hampering cooperation. As roads are a part of the overall transport network within (and across) nations, investment and planning for road infrastructure should preferably be integrated into overall national (and international) infrastructure planning. According to the 2007/08 OECD Infrastructure Questionnaire, 13 out of 25 OECD countries had national infrastructure plans in place. Operative responsibilities are, however, often separated across modes of transport, meaning that national road agencies need to coordinate with rail, sea and air agencies.

Incentives for cross-sector planning can be further weakened when targets and benchmarks are set in sector-specific terms. ${ }^{22}$ Standardisation of tools and shadow prices, for example, in terms of the assumed value of statistical life (VSL) in CBAs across modes of transport may be useful, although care has to be taken not to remove context-specific differences in prices. ${ }^{23}$ Arguably, ex post evaluations of recently finalised projects could play a role in funding, where differences in benefit-cost ratios between modes of transport could give guidance on relative funding. While coordinated and careful planning can lead to better designed infrastructure, uncertainty and excessively long planning, decision and construction processes raise costs and limit benefits of projects (HMT, 2010). Transparent and streamlined compliance regimes and appeals processes that give due weight to environmental and social costs are therefore beneficial.

22. For example, performance indicators developed for the road sector by HM Treasury in the United Kingdom and the Federal Highway Administration (FHWA) for the United States incorporate only sector-specific indicators (HMT, 2011; FHWA, 2012).

23. See e.g. the Australian Productivity Commission Report (2005) on evidence of different CBA methods across modes of transport. However, context-related differences could be attributed to e.g. voluntary and involuntary risk behaviour (Robinson and Hammitt, 2010). 
Public infrastructure projects provide opportunities for political horse trading that may lead to the selection of projects that do not have the highest benefit/cost ratios, with "bridges to nowhere" or inefficient money sprinkling as potential outcomes. Persson and Song (2010) show that in both the Netherlands and in Korea, a large share of projects with negative CBAs were given the go ahead. Ponti (2005) highlights the lack of independent CBAs in some high-profile Italian infrastructure projects. Political interventions may also favour specific modes of transport or regions. Flyvbjerg (2009) finds that traffic flows are consistently overestimated ex ante in large rail projects, while flows are underestimated for road projects. Castells and Solé-Ollé (2005) argue that infrastructure investment in Spanish regions seems more closely related to the governments' need to garner support among politically important constituencies rather than a shortage of infrastructure. Large projects with high visibility but potentially lower social returns also seem to be favoured within the European Union (Short and Kopp, 2005). Operative independence of agencies and ex post evaluations could raise the costs of political interventions. According to the 2007/08 OECD Infrastructure Survey, a minority of road sector regulators in the OECD had an independent legal status and their own budget, and only 1 out of 14 countries (Germany) reported that the executive can neither give instructions nor overturn the regulator's decision.

Decisions on infrastructure investments are also influenced by distributional concerns, especially relating to geographic differences in location and access, but also to regional employment concerns. Such considerations may explain the apparent overprovision of infrastructure in rural areas, where projected benefits of investment are often lower than costs (Brathen and Odeck, 2006). While such adjustments are legitimate, their costs should be clearly stated.

\subsection{The degree of decentralisation}

The optimal degree of decentralisation of decision making within government should be determined by two fundamental principles. On the one hand, policy settings should be sufficiently centralised for existing externalities to be internalised (Harrington, 2008). On the other hand, local governments tend to have a better understanding of local preferences and conditions and therefore have superior knowledge of local demand and supply factors. Some policy issues, such as pricing of greenhouse gases or planning of local roads, should therefore have a clear (inter-)national or local profile. Other areas, such as large and complex infrastructure projects have both national and local characteristics and need to include a wider array of stakeholders with, as a consequence, more complex decision processes. The 2007/08 OECD Infrastructure Survey indicates that local governments in most OECD countries participated in infrastructure planning but gave no information on their role in road infrastructure planning.

Even if local governments possess superior information, they often have weak incentives for revealing it. Local benefits of new infrastructure can be large, e.g. in terms of direct and indirect job creation, improved accessibility and shorter travel times, while direct costs are often borne by the central government and indirect costs could appear in other regions. This creates incentives for local governments, households and business associations to lobby for projects. Different mechanisms can be used to reveal information on local or regional conditions, for example by providing matching grants. Another example is the Norwegian framework for initiating and financing toll road construction, where local and regional government and interest groups initiate projects and - after receiving approval by the road agency and Parliament - provide the funding for the project (Brathen and Odeck, 2006).

Establishing national infrastructure agencies, such as Infrastructure Australia, can help overcome hurdles stemming from a decentralised policy setting. Such agencies could be responsible for drawing up indicative overall infrastructure and road plans. In addition, as they are the main forum where infrastructure issues and policies are analysed, they may help to raise the transparency of the decision-making process, identify main bottlenecks and enhance coordination among sub-national governments and between them and the national government. 
ECO/WKP(2013)8

\subsection{The role of the private sector}

Road infrastructure is overwhelmingly publicly owned and provided free of charge for four reasons: high fixed to variable costs, network economies, a lack of cheap technologies for collecting user fees and equity concerns. Under private provision, high fixed to variable costs lead to high market concentration, as incentives for building a competing road are often weak. This tendency is reinforced by network economics as the value of a part of the overall transport network increases with good access conditions to other parts of the network. Under such conditions, a vertically integrated network tends to be efficient. High costs of collecting user fees are also a hindrance to private provision, especially for less used roads. Across the board private provision would thus likely have to be regulated in detail to ensure sufficient access, e.g. for rural households. The role of private-sector actors has therefore mainly been confined to constructing roads, while governments plan and fund projects. Private management has often taken place only in a limited part of the network, mostly involving motorways.

The broad pros and cons of private provision of infrastructure are well known (Sutherland et al., 2009). Private-sector investors face higher borrowing costs than governments, although funding through distortionary taxes eliminates a part of this cost advantage (Brathen and Odeck, 2006). Private-sector participation in the construction and management of parts of the network could lower costs, however. Costs of producing infrastructure have been estimated to be $15-30 \%$ lower for private providers (Viscusi et al., 2000), reflecting better project management, shorter construction time and lower overheads. Combining the higher technical efficiency of private constructors with lower borrowing costs for the government could therefore be more efficient than pure public provision (Moszoro and Gasiorowski, 2008). One model for such cooperation is public procurement. In addition, government and private-sector entities have entered public private partnerships (PPPs), whereby private firms finance, build and run the infrastructure. ${ }^{24}$

The allocation of risks between the private operator and the public sector is the most contentious issue concerning private participation in infrastructure (Grimsey and Lewis, 2002). In principle, each risk should be allocated to the party best able to manage it. Typically, this means that macro-related and political risks are better borne by the government, while project-specific risks relating to construction and maintenance costs should be borne by the private sector. However, these general principles leave open the issue of how to quantify specific risks, especially of rare events, and therefore the level of compensation each party is entitled to contingent on certain circumstances.

\subsection{The use of regulatory instruments}

National - or even supranational - policies often regulate standards and the use of inputs. Centralised or supra-national regulation can help to reap benefits from economic integration and scale economies. The UN Economic Commission for Europe vehicle regulation agreement, which almost all OECD countries have signed, is one example of such supranational regulation. Regulation may be more efficient than market-based instruments when establishing a market is costly, e.g. when the use of assets or the extent of externalities is difficult to track.

Harmonised regulatory tools can also be efficient in dealing with local, national or global externalities as is the case with emission standards and the taxation and regulation of emissions of greenhouse gases. The benefits of regulation need to be weighed against the efficiency of other instruments, such as fuel

24. PPPs can take different forms. They include Build-Operate-Transfer (BOT), Build-Lease-Transfer (BLT), Build-Transfer-Operate (BTO), Design-Build-Finance-Operate (DBFO), and Design-Construct-ManageFinance (DCMF). These types of PPP differ in the private and public sectors' obligations and risk allocations. Estache et al. (2007) provide an overview of PPP types for the transport sector. 
taxes. If consumers systematically underestimate costs related to buying less fuel-efficient vehicles, this could motivate the use of a fuel standard. Unless these misconceptions are very large, however, fuel taxes tend to dominate standards in terms of efficiency (Anderson et al., 2011). The political hurdles related to raising fuel taxation in some OECD countries may, however, render standards the best available option.

The costs of imposing homogenous standards and policies on individuals with heterogeneous preferences also have to be considered. Sperling et al. (2004) estimated that emission and safety modifications due to regulations since 1967 made up roughly one-eighth of the total vehicle price in the United States. Although individuals exposed to e.g. environmental externalities may value interventions differently, perhaps due to different income levels, they have little effective choice in terms of exposure. ${ }^{25}$ Hence, standards reflecting average preferences, possibly accompanied by compensatory redistribution, are warranted. ${ }^{26}$ When external effects are less pronounced, as is the case with e.g. airbags, high regulatory standards could impose excessive costs on some consumers. However, since the introduction of airbags in US safety regulations from the early 1990s, market demand for airbags has risen faster and well above regulatory standards, suggesting that such costs are small (Sperling et al., 2004).

Restrictions on entry and prices in the freight sector and commercial passenger transport (buses and taxis) can stifle competition, reduce productivity and keep prices high. Several studies find evidence that reducing regulatory burdens in the road freight sector tends to increase efficiency and welfare (Boylaud, 2000).

\subsection{The use of economic incentives}

Economic incentives, such as taxes and subsidies, are also used to influence user inputs. Vehicle taxation can affect the stock of vehicles as well as its composition, in terms of fuel, size and safety characteristics. Fuel taxes lower traffic volumes, but also affect the vehicle fleet and driving behaviour, promoting the use of more fuel efficient cars and more economic driving (Mandell, 2009).

More targeted economic interventions may be especially suitable for addressing externalities in terms of accidents, congestion and local environmental impacts. These externalities are highly variable across time, location and road users and are therefore difficult to deal with through regulations or vehicle and fuel taxes. ${ }^{27}$ More effective instruments to manage such externalities may be underutilised; for example only 7 (out of 13) OECD countries allowed road operators to vary tolls over the course of the day, according to the 2007/08 OECD Infrastructure Questionnaire. Box 5.1 provides some examples of congestion pricing.

25. For example, evidence from the United States indicates that a $1 \%$ increase in real income leads to an increase in the value of a statistical life (VSL) of around 0.5\% (USEPA, 1999).

26. Examples of redistributive mechanisms could be tighter greenhouse gas targets in high-income countries or tighter (and more expensive) emission standards for big cars, which are predominantly bought by richer households.

27. Examples are main arteries in urban areas that tend to be congested during peak hours but with low capacity utilisation during other parts of the day. Another example is the high social costs in terms of maintenance caused by heavy freight traffic on vulnerable parts of rural networks. A third example is the social costs associated with high-risk behaviour of some drivers. 


\section{Box 5.1. Congestion pricing}

OECD economies face important costs from congestion in terms of lost time, wasted fuel and increased pollution. Congestion is estimated to cost 1 to $2 \%$ of GDP annually in developed countries (OECD/ECMT, 2007; TTI, 2011; EC, 2011). Supply-side solutions to reduce congestion - increasing road networks and lane capacity - are expensive and, in many urban areas, challenging due to limited land availability. Congestion pricing provides an alternative to tackle congestion at peak hours and encourage more efficient use of road capacity.

Demand management via variable pricing, with higher rates at traffic peaks, is commonplace for many infrastructure services (e.g. electricity provision or air travel), but has yet to become the norm in the road transport sector. Like other demand management schemes, the primary goal of congestion pricing should be to modify user habits and encourage off-peak or reduced usage. Thus, road users should respond to congestion pricing by changing routes, switching departure times, changing travel modes, or cancelling trips to avoid higher tolls.

Congestion pricing schemes comprise four broad categories: area pricing, variable tolls, high occupancy and toll (HOT) lanes and variable parking rates. Area or cordon pricing schemes (e.g. Central London and Stockholm) charge for entering and/or circulating in a high-congestion area, usually during weekday periods. Variable toll pricing (e.g. Sydney Harbour Bridge in Australia and A14 motorway in France) refers to toll roads, bridges and tunnels where toll prices are higher during peak periods. HOT lanes (e.g. Minneapolis/Saint Paul and San Diego in the United States) are specific lanes on a non-toll motorway which are reserved for carpooling, but which allow pass-holding single-occupant vehicles to use the lane for a fee. Fast lanes, with variable toll rates based on real-time congestion information, are the latest addition to this category (e.g., Tel Aviv, San Diego). Finally, variable parking pricing (e.g. New York City) refers to the management of parking to encourage parking turnover and improve circulation during peak periods in high density urban areas.

Within the last decade, several congestion pricing tools have been tested with success in OECD countries, and could usefully serve as models for wider implementation. Examples of the four congestion pricing categories are presented in Table 5.2, highlighting the goals of these schemes and their outcomes. 
Table 5.2. Selected congestion pricing programmes

\begin{tabular}{|c|c|c|c|c|c|}
\hline $\begin{array}{l}\text { City/Region/ } \\
\text { Programme }\end{array}$ & $\begin{array}{c}\text { Date } \\
\text { started }\end{array}$ & Type & Stated goals & Description & Outcomes \\
\hline $\begin{array}{l}\text { Central } \\
\text { London }\end{array}$ & 2003 & $\begin{array}{l}\text { Area } \\
\text { pricing }\end{array}$ & $\begin{array}{l}\text { Reduce congestion. } \\
\text { Allow important } \\
\text { improvements to bus } \\
\text { services. } \\
\text { Improve journey time } \\
\text { reliability for car users. } \\
\text { Improve efficiency in } \\
\text { the distribution of } \\
\text { goods and services. }\end{array}$ & $\begin{array}{l}\text { Covers central London. } \\
\text { Access charge in effect } \\
\text { between Monday and Friday, } \\
7 \text { am to } 6 \mathrm{pm} \text {, except } \\
\text { holidays. Discounts } \\
\text { available for residents and } \\
\text { for "green" vehicles. One } \\
\text { charge per day. Enforced by } \\
\text { camera checkpoints at } \\
\text { cordon and inside area, plus } \\
\text { mobile units. }\end{array}$ & $\begin{array}{l}\text { Number of vehicles in zone } \\
\text { covered reduced by } 18 \% \text {; } \\
\text { traffic delays cut by } 25 \% \text {; } \\
\text { travel speeds increased by } \\
30 \% \text {; travel time reliability up } \\
\text { significantly; bus reliability } \\
\text { and journey time improved; } \\
\text { bus use increased by } 40 \% \text {. } \\
\mathrm{CO}_{2} \text { emissions fell by } 15 \% \text { in } \\
\text { the first year of } \\
\text { implementation. }\end{array}$ \\
\hline $\begin{array}{l}\text { Sydney } \\
\text { Harbour } \\
\text { Bridge }\end{array}$ & 2008 & $\begin{array}{l}\text { Variable } \\
\text { tolls }\end{array}$ & $\begin{array}{l}\text { Ease congestion. } \\
\text { Encourage motorists } \\
\text { to travel outside peak } \\
\text { time. } \\
\text { Use revenues towards } \\
\text { public transport } \\
\text { improvements. }\end{array}$ & $\begin{array}{l}\text { Toll prices in south-bound } \\
\text { direction only, with weekday } \\
\text { peak toll charges between } \\
6.30 \text { am to } 9.30 \text { am and } 4 \mathrm{pm} \\
\text { to } 7 \mathrm{pm} \text {. Toll prices nearly } \\
40 \% \text { lower during off-peak } \\
\text { periods. }\end{array}$ & $\begin{array}{l}\text { Traffic decreased by } 9 \% \\
\text { during peak morning periods, } \\
\text { and increased by roughly } 7 \% \\
\text { during off-peak morning } \\
\text { times. }\end{array}$ \\
\hline $\begin{array}{l}\text { Minneapolis } \\
\text { / St Paul } \\
\text { MnPASS }\end{array}$ & 2005 & $\begin{array}{l}\text { HOV lanes } \\
\text { converted to } \\
\text { HOT lanes }\end{array}$ & $\begin{array}{l}\text { Part of a larger project } \\
\text { to improve traffic flow } \\
\text { using transit, tolling } \\
\text { and telework. }\end{array}$ & $\begin{array}{l}\text { Dynamically priced lanes } \\
\text { during peak hours and in } \\
\text { peak directions (real time } \\
\text { management). Reversible } \\
\text { lanes for fixed peak times } \\
\text { and flexible for special } \\
\text { events. Free for buses, } \\
\text { motorcycles and carpools. } \\
\text { Pay-as-you-use system } \\
\text { allows commuters to use } \\
\text { MnPASS as gridlock } \\
\text { insurance. }\end{array}$ & $\begin{array}{l}\text { Corridor throughput } \\
\text { increased during the peak } \\
\text { hour by up to } 5 \% \text {. Travel } \\
\text { speeds increased on the } \\
\text { general purpose lanes, as } \\
\text { well as the MnPASS lane. } \\
\text { Safety improvements include } \\
\text { a drop of } 14 \% \text { in accidents in } \\
\text { the first year of MnPASS } \\
\text { operation. }\end{array}$ \\
\hline $\begin{array}{l}\text { New York } \\
\text { City } \\
\text { PARK Smart }\end{array}$ & 2008 & $\begin{array}{l}\text { Variable } \\
\text { parking } \\
\text { pricing }\end{array}$ & $\begin{array}{l}\text { Increase parking space } \\
\text { availability. } \\
\text { Increase safety. } \\
\text { Reduce double-parking. } \\
\text { Reduce pollution. } \\
\text { Reduce congestion from } \\
\text { circling vehicles. }\end{array}$ & $\begin{array}{l}\text { The meter rate is higher } \\
\text { when demand for parking is } \\
\text { greatest and decreases } \\
\text { when demand is lower. }\end{array}$ & $\begin{array}{l}\text { Parking space occupancy } \\
\text { declined an average } 6 \% \\
\text { during peak hours and the } \\
\text { frequency of short-term } \\
\text { parking increased by } 12 \% \text { in } \\
\text { one pilot neighbourhood. }\end{array}$ \\
\hline
\end{tabular}

Source: US Federal Highway Administration; Transport for London; Australian NSW Roads and Maritime Services; Minnesota Department of Transportation; New York City DOT. 


\section{BIBLIOGRAPHY}

Anderson, S. et al. (2011), "Automobile Fuel Economy Standards: Impacts, Efficiency and Alternatives, Symposium: Transportation and the Environment", Review of Environmental Economics and Policy, Vol. 5, No. 1, pp. 89-108.

Antweiler, W. (2008), "Time-Varying Internal and External Distances and the Gravity Equation of International Trade", Working Paper Sauder School of Business.

Australian Productivity Commission (2005), Review of National Competition Policy Reforms, Productivity Commission Inquiry Report No. 33, Australian Government Productivity Commission.

Baum, H. et al. (2008), "External Costs in the Transport Sector. A Critical Review of the EC Internalisation Policy", ITF (Institute for Transport Economics at the University of Cologne).

Bickel, P. et al. (2006), "Developing Harmonised European Approaches for Transport Costing and Project Assessment", Final Technical Report.

Bougheas, S. P.O. Demetriades and E.L.W. Morgenroth (1999), "Infrastructure, Transport Costs and Trade", Journal of International Economics, Vol. 47, pp. 169-189.

Boylaud, O. (2000), Regulatory Reform in Road Freight and Retail Distribution, OECD Economics Department Working Papers, No. 255, OECD Publishing.

Braconier, H. and M. Pisu (2013), “An International Road Connectivity Index Based on Web-based Travel Time Data", OECD Economics Department Working Papers, forthcoming.

Brathen, S. and J. Odeck (2006), "Funding of Road Construction in Norway - Experiences and Perspectives", paper presented at the First International Conference on Funding Transportation Infrastructure, Banff, Canada, 2-3 August.

Castells, A. and A. Solé-Ollé (2005), “The Regional Allocation of Infrastructure Investment: The Role of Equity, Efficiency and Political Factors”, European Economic Review, No. 49, pp. 1165-1205.

CE Delft (2008), Handbook on Estimation of External Costs in the Transport Sector.

CIESIN (2005). Gridded Population of the World, version 3, Columbia University, www.ciesin.org.

Combes, P.-P., and M. Lafourcade (2005), "Transport Costs: Measures, Determinants, and Regional Policy Implications for France", Journal of Economic Geography, Vol. 5(3), pp. 319-349.

Crozet, Y. (2005), Time and Passenger Transport, ECMT Round Table 127: Time and Transport.

Cuesta, R.A. and J. Zoffio (2008), "Hyperbolic Efficiency and Parametric Distance Functions: With Application to Spanish Savings Banks", Journal of Productivity Analysis, Vol. 24(1), pp. 31-48.

Duranton, G. and M. Turner (2009), "The Fundamental Law of Road Congestion: Evidence from US Cities", Working Paper 370, University of Toronto Department of Economics, September.

Egger, P. and M. Larch (2007), "The Bilateral and Multilateral Trade Effects of Road and Railway Transport Infrastructure”, EEA-ESEM 2008. 
Estache, A., E. Juan and L. Trujillo (2007), "Public-Private Partnerships in Transport”, World Bank Policy Research Working Paper, No. 4436.

European Commission (2011), Impact Assessment, Commission Staff Working Paper, SEC(2011) 358.

Eurostat (2012), European Union Statistics on Income and Living Conditions (EU-SILC) (database).

FHWA (Federal Highway Administration, 2012), FHWA Strategic Plan, www.fhwa.dot.gov/policy/fhplan.htm\#measurement.

Flyvbjerg, B. (2009), "Survival of the Unfittest: Why the Worst Infrastructure Gets Built - and What we Can Do about it", Oxford Review of Economic Policy, Vol. 25, No. 3.

Green, W.H. (2008), “The Econometric Approach to Efficiency Analysis”, in H.O. Fried, C.A. Knox Lovell and S.S. Schmidt (eds.), The Measurement of Productive Efficiency and Productivity Change, Oxford University Press.

Grimsey, D. and M.K. Lewis (2002), "Evaluating the Risks of Public Private Partnerships for Infrastructure Projects", International Journal of Project Management, Vol. 20(2), pp. 107-118.

Harrington, W. (2008), "The Design of Effective Regulations of Transport", OECD/ITF Joint Transport Research Centre Discussion Paper, No. 2008-2.

HMT (HM Treasury) (2011), "Infrastructure Performance and Cost: Methods, Sources and Data", National Infrastructure Plan 2011, HM Treasury, Infrastructure UK.

IEA (International Energy Agency) (2011), $\mathrm{CO}_{2}$ Emissions from Fuel Combustion, IEA Publications.

IEA (International Energy Agency) (2012), IEA Energy Prices and Taxes Statistics (database).

INRIX (2010), National Traffic Scorecard.

ITF (International Transport Forum) (2010), Implementing Congestion Charges, ITF Round Tables, No. 147, OECD Publishing.

ITF (International Transport Forum) (2011a), Transport Outlook: Meeting the Needs of 9 Billion People, $\mathrm{ITF} / \mathrm{OECD}$.

ITF (International Transport Forum) (2011b), ITF Statistics Brief: Infrastructure Investment, July, $\mathrm{ITF} / \mathrm{OECD}$.

ITF (International Transport Forum) (2012), Transport Outlook: Seamless Transport for Greener Growth, ITF/OECD.

Jenelius, E. and L.-G. Mattsson (2012), "Road Network Vulnerability Analysis of Area-covering Disruptions: A Grid-based Approach with Case Study", Transportation Research Part A: Policy and Practice, Vol. 46(5), pp. 746-760.

Jenelius, E., T. Petersen and L.-G. Mattsson (2006), "Importance and Exposure in Road Network Vulnerability Analysis", Transportation Research Part A: Policy and Practice, Vol. 40(7), pp. 537-560.

Kim, K.-S. and H.-J. Cho (2005), "National Modeling for Passenger Trips in Korea", Proceedings of the Eastern Asia Society for Transportation Studies, Vol. 5, pp. 2470-2482.

Liu, W., W. Meng, X. Li and D. Zhang (2010), "DEA Models with Undesirable Inputs and Outputs", Annals of Operations Research, Vol. 173, No. 1, pp. 177-194. 
Mandell, S. (2009), “Policies towards a more Efficient Car Fleet”, Energy Policy, No. 37, pp. 5184-5191.

McMullen, S.B. and D.-W. Noh (2007), "Accounting for Emissions in the Measurement of Transit Agency Efficiency: A Directional Distance Function Approach", Transportation Research Part D: Transport and Environment, Vol. 12(1), pp. 1-9.

Meeusen, W. and J. van D. Broeck (1977), "Efficiency Estimation from Cobb-Douglas Production Functions with Composed Error", International Economic Review, Vol. 18(2), pp. 435-444.

Moszoro, M. and P. Gasiorowski (2008), "Optimal Capital Structure of Public-Private Partnerships", IMF Working Paper, No. 08/1, International Monetary Fund.

Nash, C. (2003), UNIfication of Accounts and Marginal Costs for Transport Efficiency (UNITE), European Commission $5^{\text {th }}$ Framework - Transport RTD.

Nash, C., B. Matthews, H. Link, P. Bonsall, G. Lindberg, E. van der Voorde, A. Ricci, R. Enei and S. Proost (2008), Generalisation of Research on Accounts and Cost Estimation Policy Conclusions (GRACE), European Commission $6^{\text {th }}$ Framework Programme.

Ng, C. and K. Small (2008), "Tradeoffs among Free-flow Speed, Capacity, Cost, and Environmental Footprint in Highway Design", University of California-Irvine Working Paper, 080904.

O’Donnell, C.J. and T.J. Coelli (2005), “A Bayesian Approach to Imposing Curvature on Distance Functions", Journal of Econometrics, Vol. 126(2), pp. 493-523.

OECD (2010), Health Care Systems: Efficiency and Policy Settings, OECD Publishing, 10.1787/9789264094901-en.

OECD (2012), The Economics of Climate Change Mitigation: Policies and Options for Global Action Beyond 2012, OECD Publishing.

OECD/ECMT (2007), Managing Urban Traffic Congestion, OECD Publishing.

Oosterhaven, J. and T. Knaap (2000), Spatial Economic Impacts of Transport Infrastructure Investments, Paper prepared for the TRANS-TALK Thematic Network, November.

Oxera (2010), Understanding the Theory of International Connectivity, prepared for the Department of Transport.

Papke, L.E. and J.M. Wooldridge (1996), "Econometric Methods for Fractional Response Variables with an Application to 401(k) Plan Participation Rates, Journal of Applied Econometrics, 11(6), pp. 619-632.

Persson, J. and D. Song (2010), "The Land Transport Sector: Policy and Performance", OECD Economics Department Working Papers, No. 817, OECD Publishing.

Pisu, M., P. Hoeller and I. Joumard (2012), "Options for Benchmarking Infrastructure Performance", OECD Economics Department Working Papers, No. 956, OECD Publishing.

Ponti, M. (2005), "National Systems of Transport Infrastructure Planning: The Case of Italy", in National Systems of Infrastructure Planning Round Table 128, OECD/ECMT.

Puentes, R. and A. Tomer (2008), The Road...Less Traveled: An Analysis of Vehicle Miles Traveled Trends in the U.S., Metropolitan Infrastructure Initiative Series, Brookings.

Quinet, E. (1994), “The Social Costs of Transport: Evaluation and Links with Internalisation Policies”, in OECD-ECMT, Internalising the Social Cost of Transport. 
Quinet, E. and R. Vickerman (2004), Principles of Transport Economics, Edward Elgar, Cheltenham.

Robinson, L. and J.K. Hammitt (2010), "Valuing Health and Longevity in Regulatory Analysis: Current Issues and Challenges", Jerusalem Papers in Regulation and Governance, Working Paper No. 4, May.

Schmitz, T. (2012), "Greenhouse Gas Emissions and Price Elasticities of Transport Fuel Demand in Belgium”, OECD Economics Department Working Papers, No. 955, OECD Publishing.

Schrage, A. (2006), "Traffic Congestion and Accidents", University of Regensburg Working Papers in Business, Economics and Management Information Systems 419, University of Regensburg, Department of Economics.

Schrank, D., T. Lomax and B. Eisele (2011), TTI's 2011 Urban Mobility Report, Texas Transportation Institute.

Short, J. and A. Kopp (2005), "Transport Infrastructure: Investment and Planning, Policy and Research Aspects", Transport Policy, Vol. 12, No. 4.

SIKA (2006), The National Communications Survey, Swedish Institute for Transport and Communications Analysis.

Simar, L., and P.W. Wilson (1998), "Sensitivity analysis of Efficiency Scores: How to Bootstrap in Nonparametric Frontier Models", Management Science, pp. 49-61.

Small, K. and K. van Dender (2007), "Fuel Efficiency and Motor Vehicle Travel: The Declining Rebound Effect", Energy Journal, Vol. 28, No. 1, pp. 25-51.

Sperling, D. et al. (2004), “The Price of Regulation”, Access, No. 35, Fall.

Sutherland, D., S. Araújo, B. Égert and T. Kozluk (2009), "Infrastructure Investment: Links to Growth and the Role of Public Policies", OECD Economics Department Working Papers, No. 686, OECD Publishing.

Trafikverket (2010), Pocket Facts 2010, The Swedish Transport Administration, Borlange.

TTI (Texas Transportation Institute) (2011), Urban Mobility Report, The Texas A\&M University System.

UNECE (United Nations Economic Commission for Europe), Transport Statistics (database).

USEPA (US Environmental Protection Agency) (1999), The Benefits and Costs of the Clean Air Act, 1990 to 2010, EPA 410-R-99-001.

Venables, A. and M. Gasiorek (1998), The Welfare Implications of Transport Improvements in the Presence of Market Failure, mimeo.

Vickrey, W. (1969), "Congestion Theory and Transport Investment”, The American Economic Review, Vol. 59(2), pp. 251-260.

Viscusi, W., J. Vernon and J. Harrington (2000), Economics of Regulation and Antitrust, $3^{\text {rd }}$ edition, The MIT Press, Cambridge, Massachusetts. 
ECO/WKP(2013)8

\section{APPENDIX 1}

\section{Data requirements}

The framework set out in the main paper identifies the data concepts needed to analyse road transport performance. This annex will examine these key variables, identify available data and discuss their shortcomings. Based on the available data, indicators for a set of outputs and inputs are presented by country. Finally, data not currently available which are important for measuring performance are identified, and their future collection discussed.

\section{Data requirements for measuring performance}

The analytical framework identifies three groupings of road transport data: outcomes - or in their absence - outputs, inputs and background factors (see Figure 2.3). Outcomes can be classified as desirable or undesirable. Passenger and freight tonne-kilometres, which are proxies for transport outcomes, fall into the first category. Undesirable outcomes include unforeseeable variations in travel time and congestion, accidents and environmental degradation. Major inputs into the production function are the size and the quality of the network, road network expenditure (investment plus maintenance and operation spending), and user inputs in terms of time, fleet and fuel. Background factors that may affect outcomes include the size of the economy, its geographic concentration, topography, and the availability of other transport modes.

Table A1.1 summarises the data currently available for the outputs, inputs and background factors indentified above. Data collection has been limited to international sources, in the hope of obtaining comparable data. In some cases, more than one international source exists, which is shown in the table. In order to produce indicators with the widest country coverage possible, more than one source is used for certain variables. The issues of comparability and continuity of the available data are discussed below.

\section{Comparability and continuity issues}

The analysis is hampered by a lack of harmonisation in collection methods and definitions of key data. Emissions, energy consumption ${ }^{28}$ and accident data are generally comparable, and pose little problem for most countries, but most of the other data are not harmonised. Better metadata would help clarify the extent of these issues. International agreements on collection practices, definitions and estimation methodologies would improve the reliability and usefulness of these measures, as envisaged for example by the joint OECD-ITF/JTRC Task Force (ITF, 2012) on infrastructure spending.

28. Caution is nonetheless necessary when using emission and energy consumption data, as they are both estimated based on vehicle fuel sales, and do not take into account that fuel may be purchased in one country and consumed primarily in another (see Figure 3.3 in the main text for the blatant example of Luxembourg). 
Table A1.1. Summary of data availability Outputs

\begin{tabular}{|c|c|c|c|c|c|c|c|c|c|c|c|c|c|c|c|c|c|c|c|c|c|c|c|c|c|c|c|c|c|c|}
\hline \multirow{3}{*}{$\begin{array}{c}\text { Variable } \\
\text { Source } \\
\text { Data availability }\end{array}$} & \multicolumn{6}{|c|}{$\begin{array}{l}\text { Road passenger transport (million passenger- } \\
\text { kilometres) }\end{array}$} & \multicolumn{6}{|c|}{$\begin{array}{l}\text { Road freight transport (million freight tonne- } \\
\text { kilometres) }\end{array}$} & \multirow{2}{*}{\multicolumn{3}{|c|}{\begin{tabular}{|c|}
$\begin{array}{c}\text { Road injury accidents } \\
\text { (number) }\end{array}$ \\
ITF
\end{tabular}}} & \multirow{2}{*}{\multicolumn{3}{|c|}{$\begin{array}{c}\begin{array}{c}\text { Injuries from road } \\
\text { accidents (number) }\end{array} \\
\text { ITF }\end{array}$}} & \multirow{2}{*}{\multicolumn{3}{|c|}{\begin{tabular}{|c|}
$\begin{array}{c}\text { Fatalities due to road } \\
\text { accidents (number) }\end{array}$ \\
ITF
\end{tabular}}} & \multirow{2}{*}{\multicolumn{3}{|c|}{\begin{tabular}{|c|}
$\begin{array}{c}\text { co2 emissions from } \\
\text { road transport }\end{array}$ \\
IEA
\end{tabular}}} & \multirow{2}{*}{\multicolumn{3}{|c|}{\begin{tabular}{|c|}
$\begin{array}{c}\text { Road Transport Sulphur } \\
\text { Oxides }\end{array}$ \\
OECD \\
\end{tabular}}} & \multirow{2}{*}{\multicolumn{3}{|c|}{$\begin{array}{l}\begin{array}{l}\text { Particulates (PM2.5) } \\
\text { from road transport }\end{array} \\
\text { OECD }\end{array}$}} \\
\hline & \multicolumn{3}{|c|}{ ITF } & \multicolumn{3}{|c|}{ World Bank } & \multicolumn{3}{|c|}{ ITF } & \multicolumn{3}{|c|}{ World Bank } & & & & & & & & & & & & & & & & & & \\
\hline & $\begin{array}{c}\text { Missing } \\
\text { data }\end{array}$ & $\begin{array}{l}\text { Start } \\
\text { date }\end{array}$ & End date & $\begin{array}{c}\text { Missing } \\
\text { data }\end{array}$ & $\begin{array}{l}\text { Start } \\
\text { date }\end{array}$ & End date & \begin{tabular}{c|} 
Missing \\
data
\end{tabular} & $\begin{array}{l}\text { Start } \\
\text { date }\end{array}$ & End date & \begin{tabular}{|l} 
Data \\
holes
\end{tabular} & 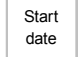 & End date & $\begin{array}{c}\text { Missing } \\
\text { data }\end{array}$ & $\begin{array}{l}\text { Start } \\
\text { date }\end{array}$ & End date & $\begin{array}{c}\text { Missing } \\
\text { data }\end{array}$ & \begin{tabular}{|l|}
$\begin{array}{l}\text { Start } \\
\text { date }\end{array}$ \\
\end{tabular} & End date & $\begin{array}{c}\text { Missing } \\
\text { data }\end{array}$ & \begin{tabular}{|l|}
$\begin{array}{l}\text { Start } \\
\text { date }\end{array}$ \\
\end{tabular} & End date & $\begin{array}{c}\text { Missing } \\
\text { data }\end{array}$ & $\begin{array}{l}\text { Start } \\
\text { date }\end{array}$ & End date & $\begin{array}{c}\text { Missing } \\
\text { data }\end{array}$ & \begin{tabular}{|l} 
Start \\
date
\end{tabular} & End date & $\begin{array}{c}\text { Missing } \\
\text { data }\end{array}$ & \begin{tabular}{|l|} 
Start \\
date
\end{tabular} & End date \\
\hline Australia & & 1970 & 2009 & & 2004 & 2008 & & 1970 & 2008 & & 2003 & 2008 & & 1989 & 1997 & & 1989 & 2008 & & 1970 & 2010 & & 1970 & 2009 & & 1990 & 2009 & & & \\
\hline Austria & & 1970 & 1992 & & 2003 & 03 & & 1970 & 2010 & yes & 1990 & 2003 & & 1970 & 2010 & & 1970 & 2010 & & 1970 & 2010 & & 1970 & 2009 & & 1990 & 2009 & yes & 1990 & 2009 \\
\hline Belgium & & 1970 & 2009 & yes & & 2008 & & 1970 & 2010 & yes & 1990 & 2008 & & 1970 & 2009 & & 1970 & 2009 & & 1970 & 2010 & & 1970 & 2009 & & 1990 & 2009 & & 2000 & 2009 \\
\hline Canada & & 1995 & 2009 & & 2001 & 2002 & & 1995 & 2009 & yes & 2001 & 2008 & & 1970 & 2009 & & 1970 & 2009 & & 1970 & 2009 & & 1970 & 2009 & & 1990 & 2009 & yes & 1990 & 2009 \\
\hline Chile & & & & & & & & & & & & & & & & & & & & & & & 1971 & 2009 & & & & & 2005 & 2009 \\
\hline Czech Republic & & 1993 & 2010 & & 1999 & 2008 & & 1993 & 2010 & & 2000 & 2008 & & 1993 & 2010 & & 1993 & 2010 & & 1993 & 2010 & & 1971 & 2009 & & 1990 & 2009 & & & \\
\hline Denmark & & 1980 & 2010 & yes & 1999 & 2008 & & 1970 & 2010 & yes & 1990 & 2008 & & 1970 & 2010 & & 1970 & 2010 & & 1970 & 2010 & & 1970 & 2009 & & 1990 & 2009 & & 2000 & 2009 \\
\hline Estonia & & 1970 & 2010 & & & 2005 & & 1970 & 2010 & yes & 1990 & 2005 & & 1970 & 20 & & 1970 & & & 1970 & 20 & & 1990 & 20 & & 1990 & 2009 & & 2000 & 2009 \\
\hline Finland & & 1970 & 2010 & & 1999 & 2008 & & 1970 & 2010 & yes & 1990 & 2008 & & 1970 & 2010 & & 1970 & 2010 & & 1970 & 2010 & & 1970 & 2009 & & 1990 & 2009 & & 2000 & 2009 \\
\hline France & & 1970 & 2010 & & 2003 & 2008 & & 1970 & 2010 & yes & 1990 & 2008 & & 1970 & 2010 & & 1970 & 2010 & & 1970 & 2010 & & 1970 & 2009 & & 1990 & 2009 & & 1990 & 2009 \\
\hline Germany & & 1970 & 2009 & yes & 2002 & 2008 & & 1970 & 2010 & yes & 1990 & 2008 & & 1970 & 2010 & & 1970 & 2010 & & 1970 & 2010 & & 1970 & 2009 & & 1990 & 2009 & & 1995 & 2009 \\
\hline Greece & & 1970 & 2008 & & 1999 & 99 & & 1970 & 2010 & yes & 1990 & 2001 & & 1970 & 2010 & & 1970 & 2010 & & 1970 & 2010 & & $1970^{\circ}$ & 2009 & & 1990 & 2009 & & & \\
\hline Hungary & & 1970 & 2010 & yes & 1999 & 2008 & & 1970 & 2010 & yes & 2000 & 2008 & & 1970 & 2010 & & 1970 & 2010 & & 1970 & 2010 & & 1970 & 2009 & & 1990 & 2009 & & 2002 & 2009 \\
\hline Iceland & & 1989 & 2009 & & & 2003 & & & & & 2002 & 2003 & & 1970 & 2010 & & 1970 & 2010 & & 1970 & 2010 & & $1970^{\prime}$ & 99 & & 1990 & 99 & & & \\
\hline Ireland & & & & & & & & 1979 & 2010 & yes & 1990 & 2003 & & 1970 & 2010 & & 1970 & 2009 & & 1970 & 2010 & & $1970^{\circ}$ & 2009 & & 1990 & 2009 & & 1990 & 2009 \\
\hline |srael & & & & & & & & & & & & & & & & & & & & & & & & 2009 & yes & 1996 & 2009 & & & \\
\hline thaly & & 1970 & 2010 & & 2001 & 2002 & & 1971 & 2010 & yes & 1990 & 2002 & & 1970 & 2010 & & 1970 & 2010 & & 1970 & 2010 & & 1970 & 2009 & & 1990 & 2009 & & 1990 & 2009 \\
\hline Japan & & 1970 & 2008 & & & 2004 & & 1970 & 2010 & yes & " 1990 & 2004 & & 1970 & 2010 & & 1970 & 2010 & & 1970 & 2010 & & 1970 & 2009 & & 1990 & 2009 & & & \\
\hline Korea & & 2001 & 2008 & & & 2006 & & 2001 & 2008 & & 2004 & 2006 & & 1970 & 2010 & & 1970 & 2010 & & 1970 & $2 c$ & & 1971 & 2009 & & 1999 & 2008 & & & \\
\hline Luxembo & & & & & & & & 1970 & 2010 & yes & 2001 & 2008 & & 1970 & 2010 & & 1970 & 2010 & & 1970 & 20 & & 1970 & 2009 & & 1990 & 09 & & & \\
\hline New Zeala & & & & & & & & 1992 & 2010 & & & & & 1970 & 201 & & 1970 & 2010 & & 1970 & 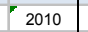 & & 1970 & 2009 & & 1990 & 2009 & & & \\
\hline Norway & & 1970 & 2010 & yes & 1999 & 2008 & & 1970 & 2010 & yes & 1990 & 2008 & & 1970 & & & 1970 & 2010 & & 1970 & 26 & & $1970^{\circ}$ & 20 & & 1990 & 2009 & & 1990 & 2009 \\
\hline Poland & & 1970 & 2010 & & 2000 & 2008 & & 1970 & 2010 & yes & 1990 & 2008 & & 1970 & 20 & & 1970 & 2010 & & 1970 & 20 & & 1970 & 2009 & & 1990 & 2009 & & 2001 & 2009 \\
\hline Portugal & & 1970 & 2008 & & & & yes & 1979 & 2010 & yes & " 1990 & 2007 & & 1970 & 20 & & 1970 & 2010 & & 1970 & $2 c$ & & 1970 & 20 & & 1990 & 2009 & & 1990 & 2009 \\
\hline Slovak Rep & & 1993 & 2010 & & 1999 & 2004 & & 1993 & 2010 & & " 1999 ' & 2006 & & 1993 & 2010 & & 1993 & 2010 & & 1993 & 2010 & & 1971 & 2009 & & 1990 & 2009 & & 2000 & 2009 \\
\hline $\begin{array}{l}\text { Slovenenia } \\
\text { Sto }\end{array}$ & & 1970 & 201 & & & 2008 & & 1970 & 2010 & yes & " & 2008 & & 1970 & 2010 & & 1970 & 2010 & & 1970 & 20 & & 1986 & 2009 & & 1990 & | & & 2000 & 2009 \\
\hline Spain & & 1970 & 2010 & & & 2003 & & 1970 & 2010 & yes & 1990 & 200 & & 1970 & 20 & & 1970 & 20 & & 1970 & 20 & & 1970 & 20 & & 1990 & & & 2000 & 009 \\
\hline Swe & & 1970 & 2010 & & 2001 & 2008 & & 1970 & 20 & yes & 1990 & 20 & & 1970 & 20 & & 1970 & 20 & & 1970 & 20 & & 15 & & & 1990 & & & & 09 \\
\hline Sw itzerland & & 1970 & 2009 & & 2002 & 2008 & & 1970 & 2010 & yes & 1990 & 2008 & & 1970 & 20 & & 1970 & 2010 & & 1970 & 20 & & 1970 " & 200 & & 1990 & 2009 & & 1990 & 2009 \\
\hline Turkey & & 1970 & 2010 & & 1999 & 2008 & & 1970 & 2010 & yes & 1995 & " 2008 & & 1970 & 2010 & & 1970 & 2010 & & 1970 & 2010 & & 1970 " & 2009 & & 1990 & 2009 & & 2000 & 2009 \\
\hline United Kingdom & & 1970 & 2010 & & 2003 & 2005 & & 1970 & 2010 & yes & 1990 & 2007 & & 1970 & 2010 & & 1970 & 2010 & & 1970 & 2010 & & 1970 & 2009 & & 1990 & 2009 & & 1990 & 2009 \\
\hline United States & yes & 1970 & 2008 & & 2001 & 2007 & & 1980 & 2008 & yes & ' 1990 ' & 2006 & & & & & 1988 & 2009 & & 1970 & 2010 & & 1970 & 2009 & & 1990 & 2009 & & 1990 & 2009 \\
\hline
\end{tabular}


Table A1.1. Summary of data availability (cont.)

Inputs

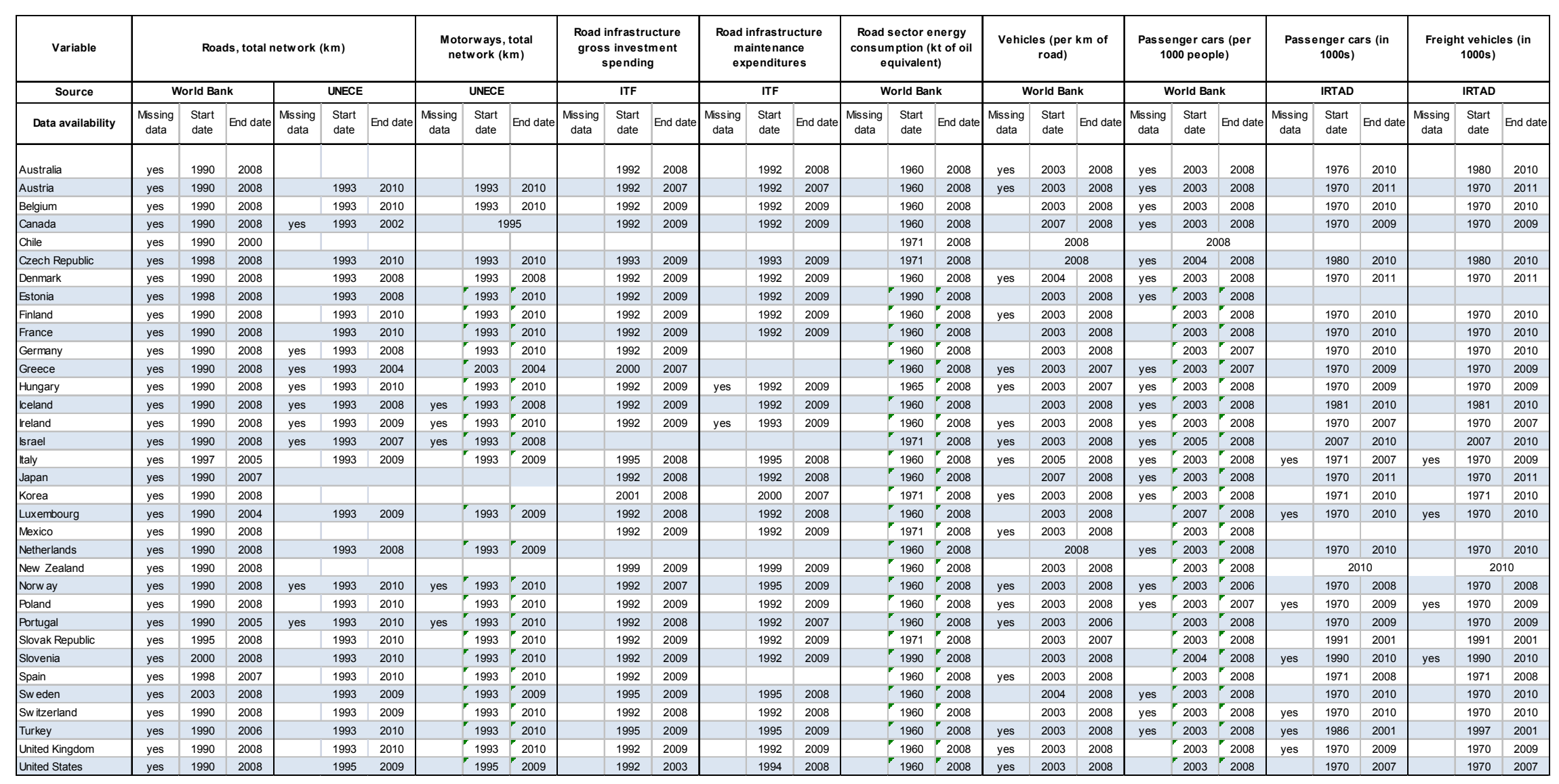


Road network length: The data suffer from a lack of standardised definitions, the most common being whether unpaved roads are included. ${ }^{29}$ The lack of standardised definitions introduces ambiguities that can influence results. Sweden, for example, had nearly 575000 road kilometres in 2008, according to the World Bank, but only 141000 kilometres according to the UNECE and Eurostat, and 220800 kilometres according to the Swedish Transport Administration. The differences are mainly due to the large number of private unsubsidised rural roads in Sweden that mainly provide access to forest harvesting. Furthermore, roads in the OECD are currently classified by level of administrative management (e.g. national, regional, local), which do not necessarily indicate the relative importance of different road categories for transporting people and goods, and which are not comparable across countries. Political decisions to decentralise the management of roads may place highly frequented highways under regional or local management. In France, the move to decentralise several national highways in 2005 resulted in a large shift of road-kilometres from the national to the regional category. The French regional road-kilometre data therefore are not comparable to those from other countries where national authorities retain control of the main transport axes. Finally, the lack of information on the lane capacity of road networks undermines the comparability of existing road network data.

Investment and maintenance: The metadata for ITF's investment and maintenance expenditure database alerts the user to the pitfalls of these data. In several countries, data cover only expenditure on motorways or main roads, and may refer to specific territories (e.g. Great Britain rather than the United Kingdom). Some country data exclude urban roads while others do not; some refer only to public sources of financing (e.g. Japan), while others include both public and private funding. While all levels of government that provide investment and maintenance should be included, for certain countries (e.g. Austria, Finland, Hungary and New Zealand), regionally and/or locally financed roads are not reported.

Road freight transport: Output is measured in tonne-kilometres. Data collection challenges arise due to the multitude of participants in the road freight transport sector, the definition of road freight transport and the need to identify activity within a country's territory versus activity taking place across countries. In an effort to harmonise road freight statistics, the European Union has enacted a number of rules for surveying and reporting data for its members. ${ }^{30}$ Eurostat requires reporting on vehicle information based on a sample of freight vehicles, collecting journey information of loaded and empty journeys by the vehicles sampled, and information on the loads transported during the reported journeys. Members are asked to report on vehicles registered in their country. Information on national transport, international transport of goods loaded or unloaded in the reporting country, cross-trade and cabotage are all derived from the micro-data reported by each country.

While the framework set up by the EU brings some harmonisation, a look at the surveys completed by member countries highlights the difficulty of the exercise. Table A1.2 provides a summary of some of the survey parameters for selected countries, illustrating the limited comparability. Despite the differences, Eurostat's road freight transport data are among the best internationally available data.

Passenger transport: Output is measured in passenger-kilometres. Data collection is much more disparate than for freight transport, being based on road surveys (for which there is no standardisation), estimates based on population density, or passenger vehicle data. Currently, there is no ongoing international harmonisation of the estimation methodology.

29. The Eurostat/ITF/UNECE Glossary for Transport Statistics (2009) defines a road as a "Line of communication (travelled way) open to public traffic, primarily for the use of road motor vehicles, using a stabilised base other than rail or air strips. Included are paved roads and other roads with a stabilised base, e.g. gravel roads." A sub-category of paved and unpaved roads exists, but the total road network should encompass both.

30. See Eurostat (2011), Road Freight Transport Methodology, Reference Manual for the Implementation of Council Regulation No. 1172/98 on statistics on the carriage of goods by road. 
Table A1.2. Survey parameters for road freight transport data collected by Eurostat

\begin{tabular}{|c|c|c|c|c|c|c|}
\hline Country & $\begin{array}{l}\text { Vehicles excluded } \\
\text { by weight }\end{array}$ & $\begin{array}{l}\text { Vehicles } \\
\text { excluded } \\
\text { by age }\end{array}$ & $\begin{array}{l}\text { Agricultural, } \\
\text { military, public } \\
\text { service vehicles } \\
\text { excluded }\end{array}$ & $\begin{array}{l}\text { Other relevant vehicle } \\
\text { exclusions }\end{array}$ & $\begin{array}{l}\text { Sampling } \\
\text { rate in } \\
\text { space }^{1}\end{array}$ & $\begin{array}{l}\text { Response } \\
\text { rate }\end{array}$ \\
\hline France & $\begin{array}{l}\text { Lorries }>32.5 \text { tonnes } \\
\text { load capacity (LC); } \\
\text { tractors }>44.5 \\
\text { tonnes; vehicles } \\
<3.5 \text { tonnes weight }\end{array}$ & $\begin{array}{l}\text { Vehicles } \\
>15 \text { years } \\
\text { old }\end{array}$ & YES & Special purpose vehicles. & $14.7 \%$ & $81.3 \%$ \\
\hline Germany & $\begin{array}{l}\text { Lorries }<3.501 \\
\text { tonnes LC }\end{array}$ & None & YES & $\begin{array}{l}\text { Vehicles not destined for the } \\
\text { transport of goods. Vehicles } \\
\text { not used for goods transport } \\
\text { on public roads. }\end{array}$ & $42.2 \%$ & $96.4 \%$ \\
\hline Ireland & $\begin{array}{l}\text { Vehicles }<2 \text { tonnes } \\
\text { un-laden weight }\end{array}$ & None & $\mathrm{NO}$ & $\begin{array}{l}\text { Vehicles not destined for } \\
\text { transport goods. Vehicles } \\
\text { taxed as non-commercial. }\end{array}$ & $46.2 \%$ & $51.4 \%$ \\
\hline Italy & $\begin{array}{l}\text { Vehicles }<3.5 \\
\text { tonnes LC }\end{array}$ & $\begin{array}{l}\text { Vehicles } \\
>11 \\
\text { years }\end{array}$ & YES & $\begin{array}{l}\text { Vehicles not destined for the } \\
\text { transport of goods. }\end{array}$ & $31.0 \%$ & n.a. \\
\hline Netherlands & $\begin{array}{l}\text { Vehicles }<3.5 \\
\text { tonnes maximum } \\
\text { permissible laden } \\
\text { weight (MPLW) }\end{array}$ & $\begin{array}{l}\text { Vehicles } \\
>25 \text { years }\end{array}$ & $\mathrm{NO}$ & $\begin{array}{l}\text { Vehicles not used for goods } \\
\text { transport on public roads. } \\
\text { Passenger vehicles. }\end{array}$ & $38.0 \%$ & $78.6 \%$ \\
\hline Spain & $\begin{array}{l}\text { Vehicles }<3.5 \\
\text { tonnes LC and } \\
<6 \text { tonnes MPLW }\end{array}$ & None & YES & $\begin{array}{l}\text { Special vehicles with high } \\
\text { weight capacity or dimensions } \\
\text { which need a special } \\
\text { registration; vehicles not } \\
\text { destined for the transport of } \\
\text { goods. }\end{array}$ & $14.3 \%$ & $93.6 \%$ \\
\hline Sweden & $\begin{array}{l}\text { Vehicles } \\
\leq 3.5 \text { tonnes LC }\end{array}$ & $\begin{array}{l}\text { Vehicles } \\
>30 \text { years }\end{array}$ & YES & $\begin{array}{l}\text { Special purpose vehicles. } \\
\text { Vehicles owned by companies } \\
\text { not in the central register. }\end{array}$ & $21.3 \%$ & $71.6 \%$ \\
\hline
\end{tabular}

1. The sampling rate in space figures (\%) have been obtained by calculating as the number of statistical units in the sample divided by the number of statistical units in the population.

Source: Eurostat (2011a), Methodologies Used in Surveys of Road Freight Transport in Member States and Candidate Countries.

Background factors: Comparability issues are fairly minor for background indicators, with good comparability for geographical and economic data such as topography (roughness) and internal distance. Cross-country comparability is more problematic for the inter-modal split - rail transport, for example, may or may not include urban rail, depending upon the country.

Comparability of data across international sources: Table A1.3 illustrates the data differences for passenger and freight tonne-kilometres in 2005 collected by three international bodies - the OECD ITF, the World Bank and Eurostat. Data differences between these sources are at times sizeable, e.g. for Korea and Poland. Better metadata, along with internationally agreed reporting and estimation conventions, could clarify why differences exist and help to harmonise data.

The time series dimension: The analysis of the road sector would be richer if longer and complete time series were available, with consistent data across time. The current state of data is quite poor in terms of consistency and completeness over time. Table A1.4 illustrates this issue, with road network kilometres from 1990 to 2008. Data are missing for all countries in 2001, and big gaps exist for several countries in various years. Changes in definitions and inconsistencies are also common (and often not signalled). In Table A1.4, the data for Canada illustrate these problems, both in terms of data holes and an apparent change in accounting. These issues would need to be addressed by international bodies, in cooperation with national transport ministries and statistical offices. 
Table A1.3. Passenger and freight movements in 2005 - a comparison of sources

\begin{tabular}{|c|c|c|c|c|c|c|}
\hline & \multicolumn{3}{|c|}{$\begin{array}{c}\text { Passenger-km, } 2005 \\
\text { Thousands }\end{array}$} & \multicolumn{3}{|c|}{$\begin{array}{l}\text { Freight tonne-km, } 2005 \\
\text { Thousands }\end{array}$} \\
\hline & \multicolumn{3}{|c|}{ World } & \multicolumn{3}{|c|}{ World } \\
\hline & ITF & Bank & Eurostat & ITF & Bank & Eurostat \\
\hline Australia & 282.0 & 290.3 & & 166.5 & 168.6 & \\
\hline Austria & & & 81.2 & 37.0 & & 37.0 \\
\hline Belgium & 127.0 & 129.0 & 127.6 & 43.8 & 48.9 & 43.8 \\
\hline Canada & 512.7 & & & 131.5 & & \\
\hline \multicolumn{7}{|l|}{ Chile } \\
\hline Czech Republic & 77.2 & 84.2 & 84.2 & 43.4 & 43.4 & 43.4 \\
\hline Denmark & 65.9 & 70.6 & & 11.1 & 11.1 & 23.3 \\
\hline Estonia & 2.9 & 3.2 & & 7.6 & 7.6 & 5.8 \\
\hline Finland & 69.5 & 70.3 & 70.4 & 31.9 & 27.8 & 31.9 \\
\hline France & 763.7 & 771.0 & & 193.2 & 193.0 & 205.3 \\
\hline Germany & 924.0 & & & 310.1 & 237.6 & 310.1 \\
\hline Greece & 42.5 & & & 15.9 & & 23.8 \\
\hline Hungary & 66.6 & & & 25.1 & 9.1 & 25.2 \\
\hline Iceland & 5.1 & & 6.1 & & & \\
\hline Ireland & & & & 18.2 & & 17.9 \\
\hline \multicolumn{7}{|l|}{ Israel } \\
\hline Italy & 778.0 & & & 171.6 & & 211.8 \\
\hline Japan & 933.0 & & & 335.0 & & \\
\hline Korea & 200.8 & 91.7 & & 100.9 & 12.5 & \\
\hline Luxembourg & & & & 0.5 & & 8.8 \\
\hline Mexico & 422.9 & 422.9 & & 204.2 & 204.2 & \\
\hline Netherlands & 164.8 & & & 34.0 & & 84.2 \\
\hline New Zealand & & & & 16.8 & & \\
\hline Norway & 58.3 & & 59.5 & 15.9 & & 18.2 \\
\hline Poland & 226.6 & 29.3 & 29.3 & 119.7 & 119.7 & 111.8 \\
\hline Portugal & 97.5 & & & 17.4 & & 42.6 \\
\hline Slovak Republic & 33.6 & & 9.2 & 22.6 & 22.6 & 22.6 \\
\hline Slovenia & 25.6 & 0.9 & 25.6 & 2.4 & 11.0 & 11.0 \\
\hline Spain & 391.0 & & 392.6 & 233.2 & & 233.2 \\
\hline Sweden & 106.1 & 112.0 & 106.9 & 34.7 & 39.4 & 38.6 \\
\hline Switzerland & 87.1 & 98.0 & 90.9 & 15.8 & 15.8 & \\
\hline Turkey & 182.2 & 182.2 & 182.2 & 166.8 & 166.8 & \\
\hline United Kingdom & 710.7 & 736.0 & 706.0 & 165.5 & 163.0 & 161.3 \\
\hline United States & 4582.3 & 7866.4 & & 1885.6 & 1885.6 & \\
\hline
\end{tabular}

Source: ITF; World Bank Development Indicators; Eurostat.

\section{Indicators based on available data}

Output and input data are presented in the form of diamonds, in units of standard deviation around the OECD average. When data were available from more than one source for a variable, the source with the largest country coverage was chosen. If necessary, the data were supplemented by other sources. Table A1.5 summarises the sources and dates of the data used in these diamonds. All data are scaled by real GDP in 2005 PPP dollars, with the exception of investment and maintenance expenditure, which are scaled by nominal GDP. Examples of diamond output and input indicators are discussed in the main paper (Figures 3.2 and 3.3). The full set of diamond output and input indicators, for all OECD countries, are shown in Figures A1.2 and A1.3, which are located at the end of this annex. 
Table A1.4. Total road network kilometres in OECD countries

\begin{tabular}{|c|c|c|c|c|c|c|c|c|c|c|c|c|c|c|c|c|c|c|c|}
\hline & 1990 & $1991^{\prime}$ & 1992 & $1993^{\prime}$ & 1994 & $1995^{\prime}$ & $1996^{\prime \prime}$ & 1997 & $1998^{\prime}$ & $1999^{\prime}$ & $2000^{\prime \prime}$ & 2001 & $2002^{\prime}$ & 2003 & 2004 & 2005 & 2006 & 2007 & 2008 \\
\hline Australia & 810264 & 828000 & 844000 & 860000 & 878000 & 896000 & 913000 & & 913000 & 811601 & 811601 & & & 812972 & & & & 817114 & 818356 \\
\hline Austria & 107838 & 112208 & 109045 & 129419 & 129282 & 130023 & 129055 & 129405 & 133361 & 132959 & 132999 & & 133635.7 & 133928 & & 105660 & 107262 & 107206 & 110778 \\
\hline Belgium & 138876 & 139341 & 139922 & 140729 & 141430 & 143175 & 144913 & 145850 & 145850 & 147121 & 148216 & & 149739 & 149739 & 150567 & 151372 & 152256 & 153088 & 153595 \\
\hline Canada & 825743 & 849404 & 901903 & & & 901902 & & & 901903 & 901903 & & & 1408900 & & 1408900 & & 1409000 & 1409000 & 1409000 \\
\hline Czech Republic & & & & & & & & & 127693 & 127693 & 127708 & & 127672 & 127672 & 128426 & 128437 & 130504 & 130503 & 130573 \\
\hline Denmark & 70922 & 71042 & 71040 & 71111 & 71255 & 71255 & 71321 & 71336 & 71437 & 71454 & 71591 & & 71847 & 71847 & 72075 & 72257 & 72362 & 72412 & 73257 \\
\hline Estonia & & & & & & & & & 49480 & 50436 & 51411 & & 55944 & 56849 & 56839 & 57016 & 57025 & 57565 & 58034 \\
\hline Finland & 76407 & 76631 & 76755 & 77499 & 77644 & 77722 & 77782 & 77796 & 77895 & 77900 & 78412 & & 78138 & 78197 & 78158 & 78821 & 78941 & 78889 & 78860 \\
\hline France & 885600 & 890750 & 891200 & 891600 & 892500 & 892700 & 892500 & 892900 & 893300 & 893500 & 894000 & & 891320 & 950000 & 951220 & 950985 & 951225 & 951125 & 951200 \\
\hline Greece & 116070 & 116000 & 116150 & 117000 & 117000 & 117000 & 117000 & 117000 & 117000 & 116470 & 116470 & & & 114931 & 114931 & 117533 & 116631 & 116631 & 116711 \\
\hline Hungary & 105774 & 105930 & 158711 & 158565 & 158633 & 158633 & 158633 & & 158753 & 158747 & 158785 & & 159568 & 159568 & & 159600 & 192978 & 195719 & 197534 \\
\hline Iceland & 11378 & 11291 & 11373 & 11279 & 11500 & 12378 & 12341 & 12691 & 12689 & 12681 & 12962 & & 12978 & 12988 & 12972 & 13029 & 13038 & 13048 & 13048 \\
\hline Ireland & 92303 & 92327 & 92327 & 92345 & 92500 & 92500 & 92500 & 92500 & 95709 & 95694 & 95694 & & 95736 & 96602 & & & & 96418 & 96424 \\
\hline Israel & 13199 & 13409 & 13623 & 13929 & 14392 & 14751 & 15149 & 15583 & 15977 & 16121 & 16449 & & 16972 & 17253 & 17446 & 17589 & 17719 & 17872 & 18096 \\
\hline |taly & & & & & & & & 478272 & 479545 & 479688 & 479688 & & & 484688 & & 487700 & & 487700 & 487700 \\
\hline Japan & 1114697 & 1115609 & 1124844 & 1130892 & 1137453 & 1142308 & 1147532 & 1152207 & 1156371 & 1161894 & 1166340 & & 1177278 & 1182593 & 1187638 & 1192400 & 1197008 & 1200858 & 1200858 \\
\hline brea & 56715 & 58088 & 58905 & 61296 & 78833 & 74237 & 82342 & 84968 & 86990 & 86990 & 86990 & & 96037 & 97252 & 100279 & 102293 & 102062 & 103019 & 104237 \\
\hline Luxembourg & 5091 & 5097 & 5108 & 5113 & 5134 & 5136 & 5161 & 5171 & 5166 & 5189 & 5210 & & 5204 & 5225 & 5227 & & & 5227 & 5227 \\
\hline Mexico & 239235 & 242294 & 243856 & 243203 & 303414 & 307983 & 312301 & 323977 & 318952 & 329532 & 329532 & & 337192 & 349037 & 352072 & 355796 & 356945 & 360075 & 366096 \\
\hline Netherlands & 104590 & 104831 & 104831 & 118100 & 120000 & 122000 & 124100 & 124825 & 125575 & 116500 & 116500 & & & 126100 & & 134218 & 134948 & 135470 & 136135 \\
\hline New Zealand & 92674 & 93191 & 93348 & 92306 & 92700 & 91875 & 91864 & 91967 & 92142 & 92075 & 92053 & & 92514 & 92931 & 93149 & 93460 & 93631 & 93748 & 93911 \\
\hline Poland & 363116 & 365365 & 367000 & 368364 & 370510 & 372479 & 374990 & 377048 & 381046 & 381046 & 364656 & & 372744 & 423997 & 379194 & 381463 & 382615 & 383053 & 383313 \\
\hline Portugal & 65500 & 66595 & 67719 & 68901 & 67511 & 68732 & & & & 68732 & 68732 & & 72600 & 79405 & 78470 & 82900 & & 82900 & 82900 \\
\hline Slovak Republic & & & & & & 42440 & 42439 & 42606 & 42689 & & 42958 & & 42970 & 42993 & 43000 & 43745 & 43761 & 43817 & 43848 \\
\hline Slovenia & & & & & & & & & & & 38403 & & 38521 & 38400 & 38450 & 38485 & 38562 & 38708 & 38872 \\
\hline Spain & & & & & & & & & 664822 & 663795 & 664024 & & 665243 & 666291.5 & & & 667392 & 667064 & 667064 \\
\hline Sw eden & & & & & & & & & & & & & & 424781 & 424947 & 425383 & 426332 & 427045 & 574741 \\
\hline Sw itzerland & 71099 & 71106 & 71118 & 71134 & 71027 & 71055 & 71117 & 71048 & 71059 & 71115 & 71011 & & 71212 & 71171 & 71214 & 71296 & 71298 & 71354 & 71355 \\
\hline Turkey & 367409 & 367608 & 386704 & 388093 & 381028 & 381300 & 381631 & 382397 & 382059 & 385960 & & & & 426577 & 426906 & 426914 & 426951 & 426951 & 426951 \\
\hline United Kingdom & 358034 & 359966 & 362310 & 384839 & 385557 & 386401 & 386983 & 387893 & 388641 & 389514 & 390238 & & 389649 & 392342 & 387674 & 388008 & 419526 & 420009 & 419634 \\
\hline United States & 6243163 & 6257882 & 6277859 & 6284038 & 6286973 & 6296107 & 6308086 & 6348227 & 6310192 & 6327964 & 6358665 & & & 6421037 & 6433272 & 6544257 & & 6489079 & 6506221 \\
\hline
\end{tabular}


Table A1.5. Summary of sources and dates for the input and output indicator diamonds

\begin{tabular}{|c|c|c|c|c|c|c|c|c|}
\hline \multirow[b]{4}{*}{ Australia } & \multicolumn{8}{|c|}{ Outputs } \\
\hline & \multicolumn{2}{|c|}{ Freight tonne-kilometres } & \multicolumn{2}{|c|}{ Passenger-kilometres } & \multicolumn{2}{|c|}{$\mathrm{CO}_{2}$ emissions } & \multicolumn{2}{|c|}{$\begin{array}{c}\text { Injuries due to vehicle } \\
\text { accidents }\end{array}$} \\
\hline & Source & Years & Source & Years & Source & Years & Source & Years \\
\hline & ITF & 2001-08 & ITF & 2001-09 & IEA & 2001-09 & ITF & 2001-09 \\
\hline Austria & ITF & $2001-10$ & & no data & IEA & 2001-09 & ITF & $2001-10$ \\
\hline Belgium & ITF & $2001-10$ & ITF & 2001-09 & IEA & 2001-09 & ITF & 2001-09 \\
\hline Canada & ITF & 2001-09 & ITF & 2001-09 & IEA & 2001-09 & ITF & 2001-09 \\
\hline Chile & & no data & & no data & IEA & 2001-09 & & no data \\
\hline Czech Republic & ITF & $2001-10$ & ITF & 2001-10 & IEA & 2001-09 & ITF & $2001-10$ \\
\hline Denmark & ITF & $2001-10$ & ITF & $2001-10$ & IEA & 2001-09 & ITF & $2001-10$ \\
\hline Estonia & ITF & $2001-10$ & ITF & $2001-10$ & IEA & 2001-09 & ITF & $2001-10$ \\
\hline Finland & ITF & $2001-10$ & ITF & $2001-10$ & IEA & 2001-09 & ITF & $2001-10$ \\
\hline France & ITF & $2001-10$ & ITF & $2001-10$ & IEA & 2001-09 & ITF & $2001-10$ \\
\hline Germany & ITF & $2001-10$ & ITF & 2001-09 & IEA & 2001-09 & ITF & $2001-10$ \\
\hline Greece & ITF & $2001-10$ & ITF & 2001-08 & IEA & 2001-09 & ITF & $2001-10$ \\
\hline Hungary & ITF & $2001-10$ & ITF & $2001-10$ & IEA & 2001-09 & ITF & $2001-10$ \\
\hline Iceland & & no data & ITF & 2001-09 & IEA & 2001-09 & ITF & $2001-10$ \\
\hline Ireland & ITF & $2001-10$ & & no data & IEA & 2001-09 & ITF & 2001-09 \\
\hline Israel & & no data & & no data & IEA & 2001-09 & & no data \\
\hline Italy & ITF & $2001-10$ & ITF & $2001-10$ & IEA & 2001-09 & ITF & $2001-10$ \\
\hline Japan & ITF & $2001-10$ & ITF & 2001-08 & IEA & 2001-09 & ITF & $2001-10$ \\
\hline Korea & ITF & 2001-08 & ITF & 2001-08 & IEA & 2001-09 & ITF & 2001-10 \\
\hline Luxembourg & ITF & $2001-10$ & & no data & IEA & 2001-09 & ITF & $2001-10$ \\
\hline Mexico & ITF & $2001-10$ & ITF & $2001-10$ & IEA & 2001-09 & ITF & 2001-09 \\
\hline Netherlands & ITF & $2001-10$ & ITF & 2001-08 & IEA & 2001-09 & ITF & $2001-10$ \\
\hline New Zealand & ITF & $2001-10$ & & no data & IEA & 2001-09 & ITF & $2001-10$ \\
\hline Norway & ITF & $2001-10$ & ITF & $2001-10$ & IEA & 2001-09 & ITF & $2001-10$ \\
\hline Poland & ITF & $2001-10$ & ITF & $2001-10$ & IEA & 2001-09 & ITF & $2001-10$ \\
\hline Portugal & ITF & $2001-10$ & ITF & 2001-08 & IEA & 2001-09 & ITF & $2001-10$ \\
\hline Slovak Republic & ITF & $2001-10$ & ITF & $2001-10$ & IEA & 2001-09 & ITF & 2001-10 \\
\hline Slovenia & ITF & 2001-10 & ITF & $2001-10$ & IEA & 2001-09 & ITF & $2001-10$ \\
\hline Spain & ITF & $2001-10$ & ITF & $2001-10$ & IEA & 2001-09 & ITF & $2001-10$ \\
\hline Sweden & ITF & $2001-10$ & ITF & $2001-10$ & IEA & 2001-09 & ITF & $2001-10$ \\
\hline Switzerland & ITF & $2001-10$ & ITF & 2001-09 & IEA & 2001-09 & ITF & $2001-10$ \\
\hline Turkey & ITF & $2001-10$ & ITF & 2001-10 & IEA & 2001-09 & ITF & $2001-10$ \\
\hline United Kingdom & ITF & $2001-10$ & ITF & $2001-10$ & IEA & 2001-09 & ITF & $2001-10$ \\
\hline United States & ITF & 2001-08 & ITF & 2001-08 & IEA & 2001-09 & ITF & 2001-09 \\
\hline
\end{tabular}


ECO/WKP(2013)8

Table A1.5. Summary of sources and dates for the input and output indicator diamonds (cont.)

\begin{tabular}{|c|c|c|c|c|c|c|c|c|c|c|c|c|}
\hline \multirow{3}{*}{ Australia } & \multicolumn{12}{|c|}{ Inputs } \\
\hline & \multicolumn{2}{|c|}{ Total road network $(\mathrm{km})$} & \multicolumn{2}{|c|}{ Motorways $(\mathrm{km})$} & \multicolumn{2}{|c|}{$\begin{array}{l}\text { Investment and } \\
\text { maintenance }\end{array}$} & \multicolumn{2}{|c|}{ Passenger cars } & \multicolumn{2}{|c|}{ Goods vehicles } & \multicolumn{2}{|c|}{ Energy consumption } \\
\hline & Source & Year & Source & Years & Source & Years & Source & Years & Source & Years & Source & Years \\
\hline Austria & WB & $2002-03,2005-08$ & UNECE & $2001-10$ & ITF & 1992-2007 & IRTAD & $2001-10$ & IRTAD & $2001-10$ & WB & $2001-08$ \\
\hline Belgium & WB & $2002-08$ & UNECE & 2001-10 & ITF & $1992-2009$ & IRTAD & $2001-10$ & IRTAD & $2001-10$ & WB & $2001-08$ \\
\hline Canada & WB & $2002,2004,2006-08$ & IRF & 2009 & ITF & $1992-2009$ & IRTAD & 2001-09 & IRTAD & 2001-09 & WB & $2001-08$ \\
\hline Chile & IRF & 2009 & IRF & 2009 & IRF & 2009 & IRF & 2009 & IRF & 2009 & WB & $2001-08$ \\
\hline Czech Republic & WB & $2002-08$ & UNECE & $2001-10$ & ITF & 1993-2009 & IRTAD & 2010 & IRTAD & $2001-10$ & WB & $2001-08$ \\
\hline Estonia & WB & $2002-08$ & UNECE & $2001-10$ & ITF & $1992-2009$ & & no data & & no data & WB & $2001-08$ \\
\hline Finland & WB & $2002-08$ & UNECE & 2001-10 & ITF & $1992-2009$ & IRTAD & $2001-10$ & IRTAD & $2001-10$ & WB & $2001-08$ \\
\hline France & WB & $2002-08$ & UNECE & 2001-10 & ITF & $1992-2009$ & IRTAD & $2001-10$ & IRTAD & $2001-10$ & WB & $2001-08$ \\
\hline Germany & WB & $2006-08$ & UNECE & $2001-10$ & ITF & $1992-2009$ & IRTAD & $2001-10$ & IRTAD & $2001-10$ & WB & $2001-08$ \\
\hline Greece & WB & 2003-08 & UNECE & 2003-04 & ITF & $2000-07$ & IRTAD & 2001-09 & IRTAD & 2001-09 & WB & $2001-08$ \\
\hline Hungary & WB & $2002-03,2005-08$ & UNECE & 2001-10 & ITF & $1992-2009$ & IRTAD & 2001-09 & IRTAD & $2001-09$ & WB & 2001-08 \\
\hline Iceland & WB & $2002-08$ & UNECE & $2001-05,2008$ & ITF & $1992-2009$ & IRTAD & 2001-10 & IRTAD & $2001-10$ & WB & $2001-08$ \\
\hline Ireland & WB & $2002-03,2007-08$ & UNECE & $2001-05,2008-10$ & ITF & 1993-2009 & IRTAD & 2001-07 & IRTAD & $2001-07$ & WB & $2001-08$ \\
\hline Israel & WB & $2002-08$ & UNECE & $2001-02,2005-08$ & & no data & IRTAD & $2007-10$ & IRTAD & $2007-10$ & WB & $2001-08$ \\
\hline Italy & WB & 2003. 2005. 2007 & UNECE & 2001-09 & ITF & $1995-2008$ & IRTAD & $2001-04,2007$ & IRTAD & 2001-04, 2009 & WB & $2001-08$ \\
\hline Japan & WB & $2002-07$ & IRF & 2009 & ITF & $1992-2008$ & IRTAD & $2001-10$ & IRTAD & $2001-10$ & WB & $2001-08$ \\
\hline Mexico & WB & $2002-08$ & IRF & 2009 & ITF & $1992-2009$ & & no data & & no data & WB & $2001-08$ \\
\hline Netherlands & WB & $2003,2005-08$ & UNECE & 2001-09 & & no data & IRTAD & $2001-10$ & IRTAD & $2001-10$ & WB & $2001-08$ \\
\hline New Zealand & WB & $2002-08$ & IRF & 2009 & ITF & 1999-2009 & IRTAD & 2010 & IRTAD & 2010 & WB & $2001-08$ \\
\hline Norway & WB & $2002-03,2005-08$ & UNECE & $2001-02,2004-10$ & ITF & $1992-2007$ & IRTAD & 2001-08 & IRTAD & $2001-08$ & WB & $2001-08$ \\
\hline Poland & WB & $2002-08$ & UNECE & $2001-10$ & ITF & $1992-2009$ & IRTAD & 2001-09 & IRTAD & 2001-09 & WB & $2001-08$ \\
\hline Portugal & WB & $2002-05,2007$ & UNECE & $2001-02,2005-10$ & ITF & $1992-2008$ & IRTAD & 2001-09 & IRTAD & 2001-09 & WB & $2001-08$ \\
\hline Slovak Republic & WB & $2002-08$ & UNECE & $2001-10$ & ITF & $1992-2009$ & IRTAD & 2001 & IRTAD & 2001 & WB & $2001-08$ \\
\hline Slovenia & WB & $2002-08$ & UNECE & $2001-10$ & ITF & $1992-2009$ & & no data & IRTAD & $2001-10$ & WB & $2001-08$ \\
\hline Spain & WB & $2002-03,2006-07$ & UNECE & 2001-10 & ITF & $1992-2009$ & IRTAD & 2001-08 & IRTAD & $2001-08$ & WB & $2001-08$ \\
\hline Sweden & WB & 2003-07 & UNECE & 2001-09 & ITF & $1995-2009$ & IRTAD & $2001-10$ & IRTAD & $2001-10$ & WB & $2001-08$ \\
\hline Switzerland & WB & $2002-08$ & UNECE & $2001-10$ & ITF & $1992-2008$ & IRTAD & $2001-10$ & IRTAD & $2001-10$ & WB & $2001-08$ \\
\hline Turkey & WB & 2003-07 & UNECE & 2001-10 & ITF & $1995-2009$ & IRTAD & 2001 & IRTAD & 2001 & WB & $2001-08$ \\
\hline United Kingdom & WB & $2001-08$ & UNECE & $2001-10$ & ITF & $1992-2009$ & IRTAD & 2001-09 & IRTAD & $2001-09$ & WB & $2001-08$ \\
\hline United States & WB & $2003-05,2007-08$ & UNECE & 2001-09 & ITF & $1992-2003$ & IRTAD & $2001-08$ & IRTAD & $2001-07$ & WB & $2001-08$ \\
\hline
\end{tabular}




\section{Key data not yet available}

The framework set out in this paper identifies several key variables needed in order to analyse road infrastructure efficiency. As seen above, internationally comparable data, with harmonised definitions and collection methods, are only available for a handful of variables, and often for a limited number of countries. In addition, existing data are often poor in terms of consistency and availability over time. Another set of variables is simply not yet available, either due to a lack of collection at the national level or a lack of international agreement on definitions.

The capacity of road networks, measured in terms of lane-kilometres, is important for constructing measures of efficiency, but data are not collected at the national level. Piecemeal information is available from a number of different sources (local transport authorities, regional services, private mapping providers), but reconciling and mapping between various sources has not been undertaken to our knowledge by any national administration. However, without adequate data on road capacity, making inferences about the efficiency of passenger and freight movements is difficult. Road quality, often measured by pavement quality, is frequently collected by local road authorities. However, these data are rarely aggregated at the national level, due to a lack of standardised methodology, and therefore no data are available on a cross-country basis.

Data regarding spending on investment, maintenance and management of the road network need to be completed and harmonised. Administrative costs are currently not available from international sources, and spending at all levels of government (and the private sector) on management, maintenance and investment is not available. Specific employment data, both with regard to road network management, but also other road-related employment (road construction, road-based transportation) are not currently collected at the international level, and would add an important dimension to the analysis of the road sector and the social efficiency of road infrastructure.

Travel time data (and possibly real travel speeds) are important for measuring efficiency of the road transport sector. Internationally comparable time use survey data exist for just a few countries, with information on average time individuals spend on road travel (Figure A1.1). Internationally comparable data on traffic congestion and variability in travel time are even rarer, although INRIX (2010) provides comparable estimates for six OECD countries. As illustrated in Box 2.2, new technologies exist for tracking traffic which, given national resources and internationally agreed parameters, would permit the calculation of travel speed, congestion and time variability indicators.

Figure A1.1. Average time spent in car, motorcycle and van travel per day

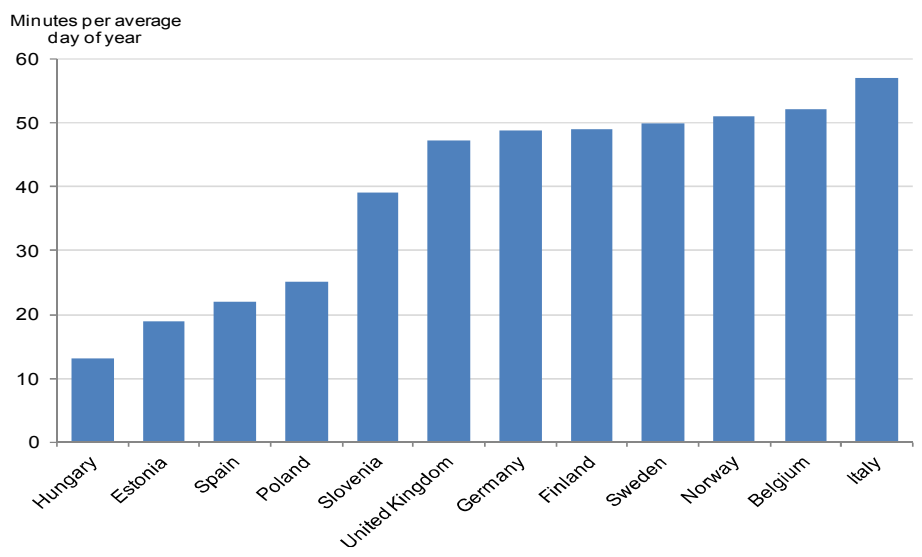

Source: Harmonised European Time Use Survey (HETUS). 
Finally, several important concepts in transport economics - such as accessibility, connectivity and network resilience - are conceptually vague, and neither agreed definitions nor internationally comparable data exist. Steps towards the development of definitions and agreement on a methodology to quantify these concepts in order to produce comparable cross-country data would be welcome. Box 3.1 gives one example of how connectivity can be estimated.

\section{The need for a concerted data collection effort}

In order to improve the empirical analysis, and given the present state of data, priority should be given to the following areas of data development:

- Standardisation of data definitions and collection methodology for already existing data;

- Collection of data at the national level (and following internationally agreed methodologies and definitions) for key information:

- Lane-kilometres for road capacity; ideally roads should be separated in motorways, inter-urban roads and urban and local roads (with clearly defined metrics for these classifications);

- Operational, maintenance and investment spending, with coverage of both the public sector (all levels of government) and the private sector;

- Road-management sector employment; and

- Road travel time so as to measure user costs;

- Definition of data proxies to quantify the following concepts:

- Traffic congestion;

- Travel time predictability;

- Road quality; and

- Connectivity.

International agreement on definitions, collection techniques and estimation methodologies are necessary to produce and maintain comparable information of quality indicators. There exists a rich body of work already accomplished by the EUROSTAT/ITF/UNECE, Glossary for Transport Statistics, which could be used as a starting point for future work. National transport ministries would need to be actively involved in cooperation with national statistical offices, to ensure that local level data are collected and processed following international standards, in order to produce coherent and comparable aggregate data.

Each member country would need to make the investment to expand its data collection to cover the key areas, and to ensure that their reporting meets internationally agreed principles. Eurostat has already made important advances towards harmonisation of many important data concepts. A mapping process between Eurostat/UNECE/ITF definitions and methodologies, and those of the non-EU countries is needed to ensure that the international data are comparable. The OECD International Transport Forum has a key role to play in coordinating, along with EUROSTAT, and processing harmonised data. 
Figure A1.2. Road output indicators

Average 2001-10, scaled by real GDP in USD at 2005 PPP
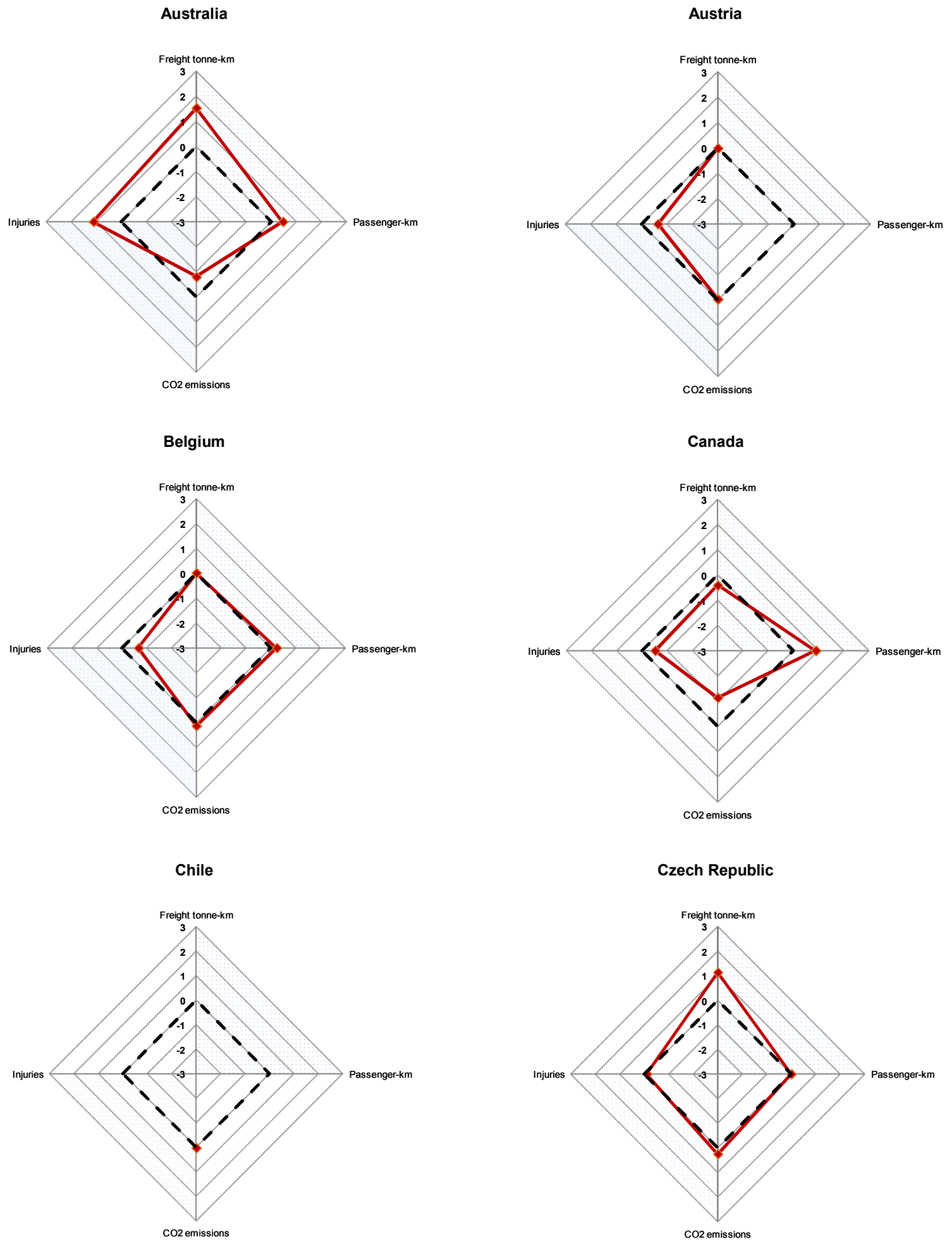
ECO/WKP(2013)8

Figure A1.2. Road output indicators (cont.)
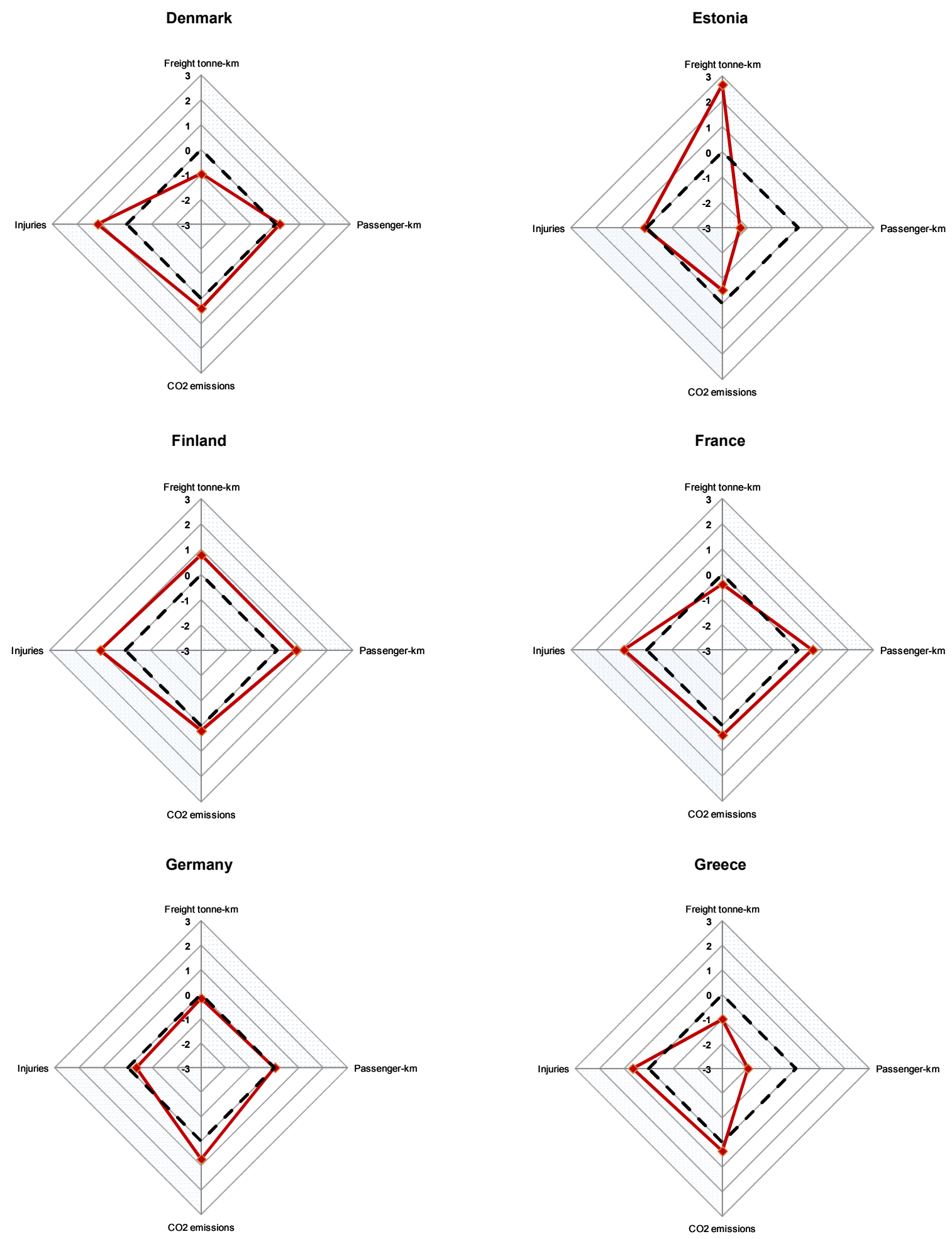
ECO/WKP(2013)8

Figure A1.2. Road output indicators (cont.)
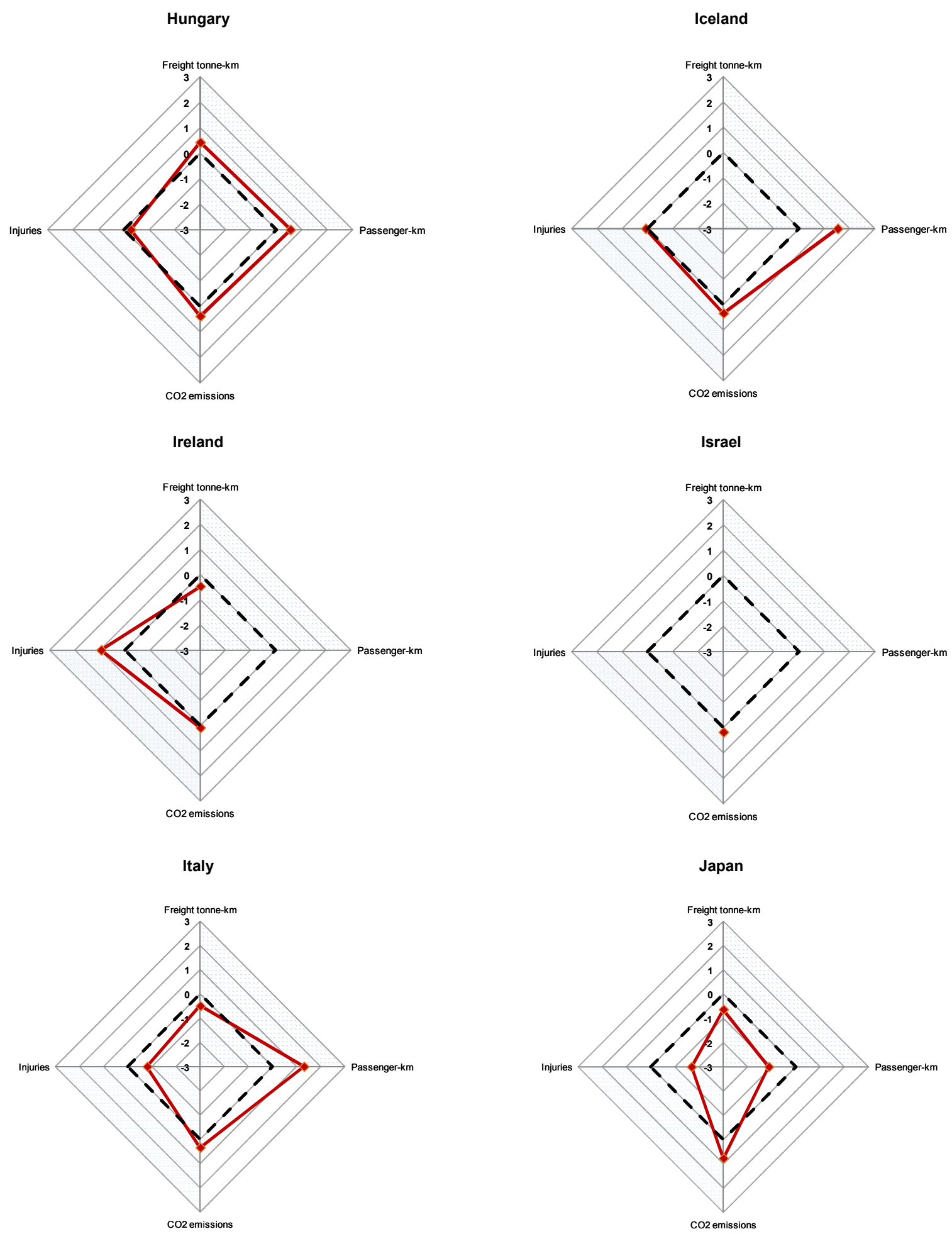
Figure A1.2. Road output indicators (cont.)
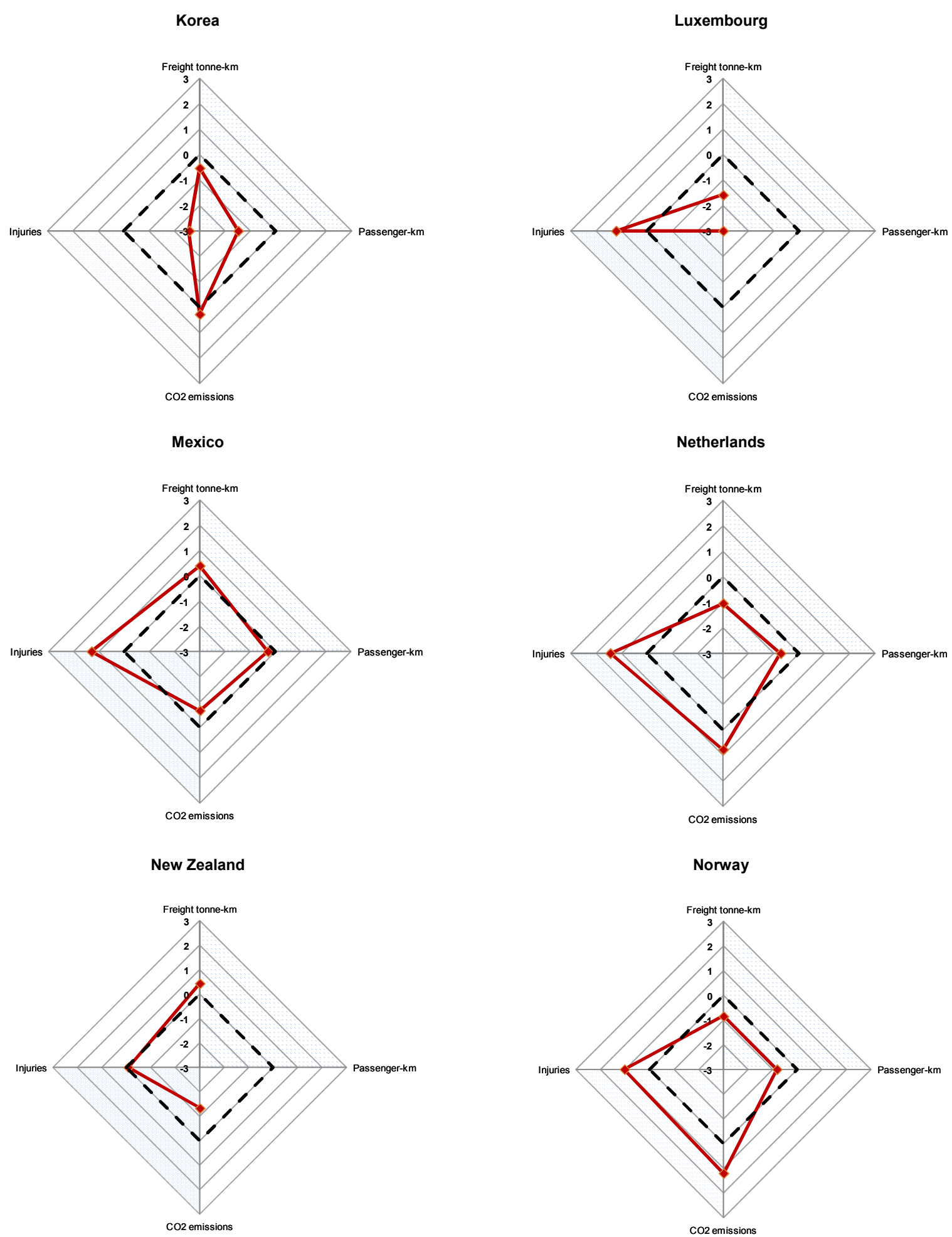
ECO/WKP(2013)8

Figure A1.2. Road output indicators (cont.)
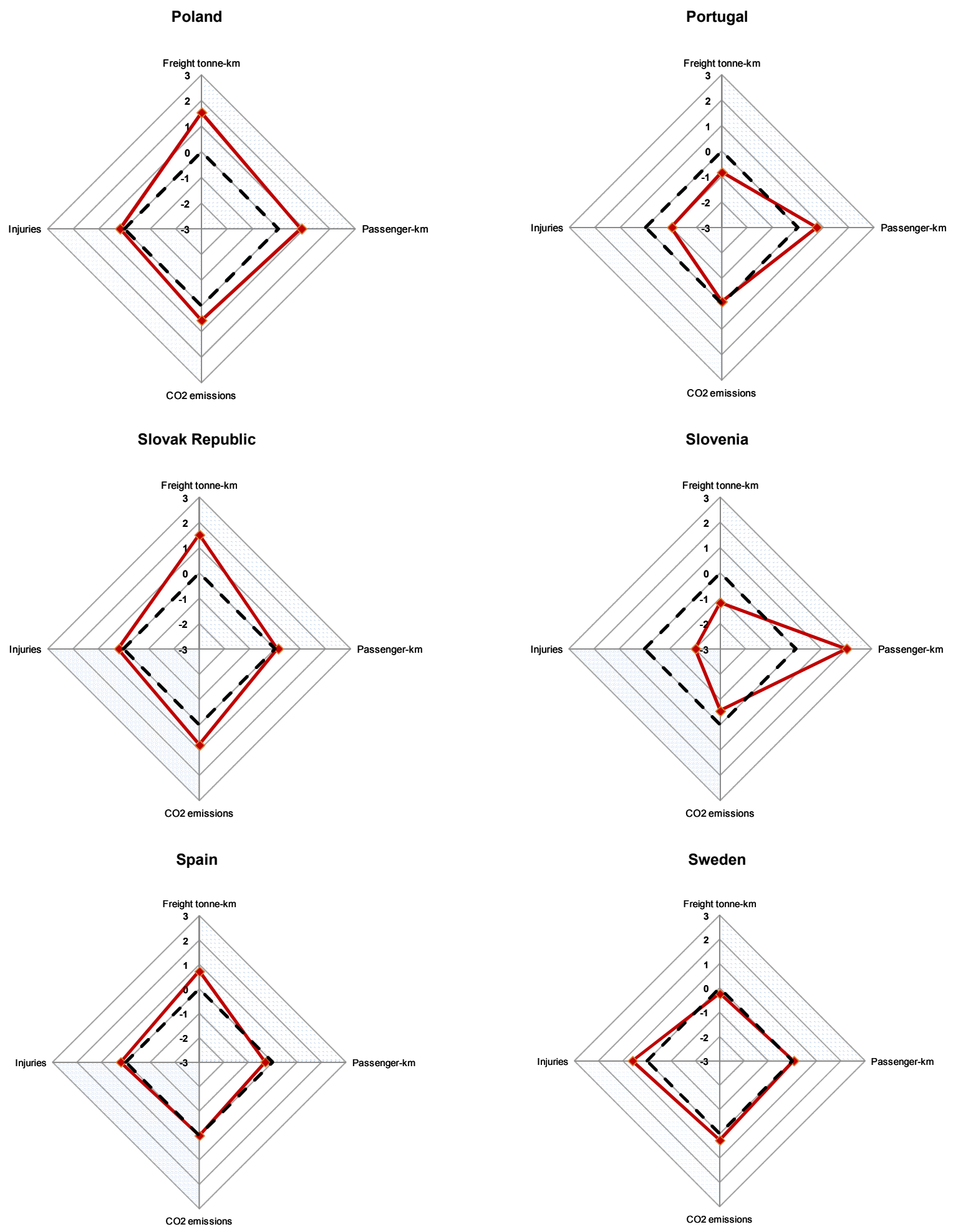
Figure A1.2. Road output indicators (cont.)

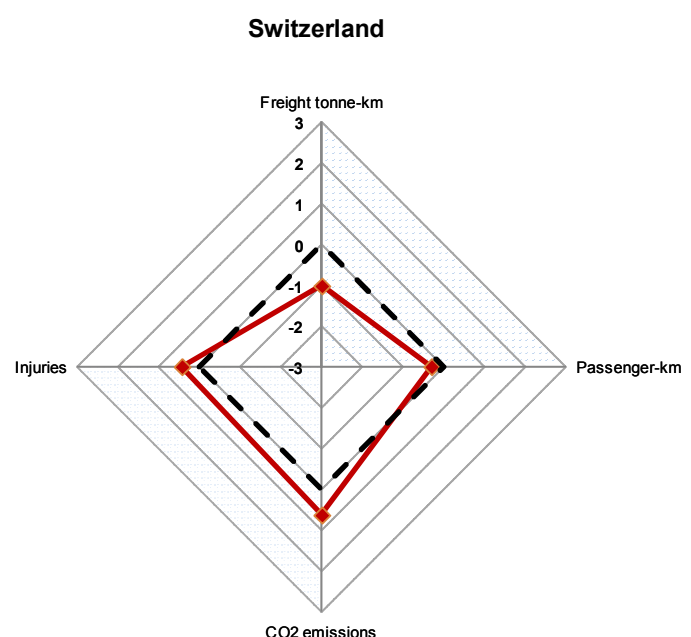

United Kingdom

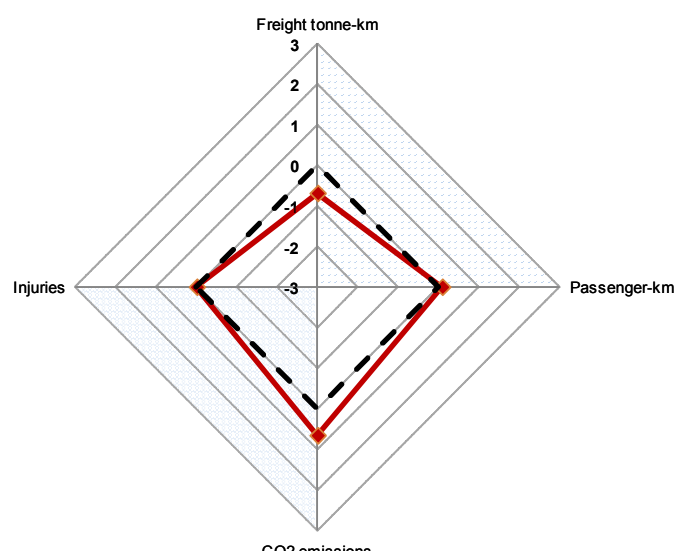

co2 emissions

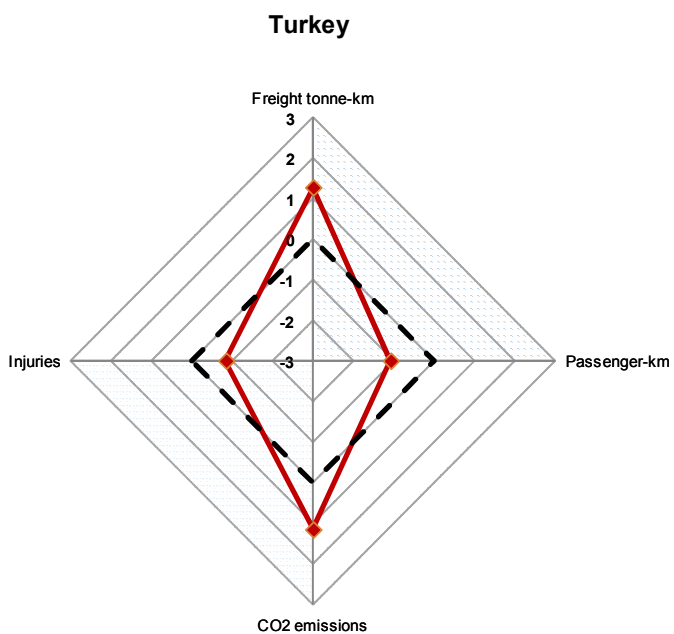

United States

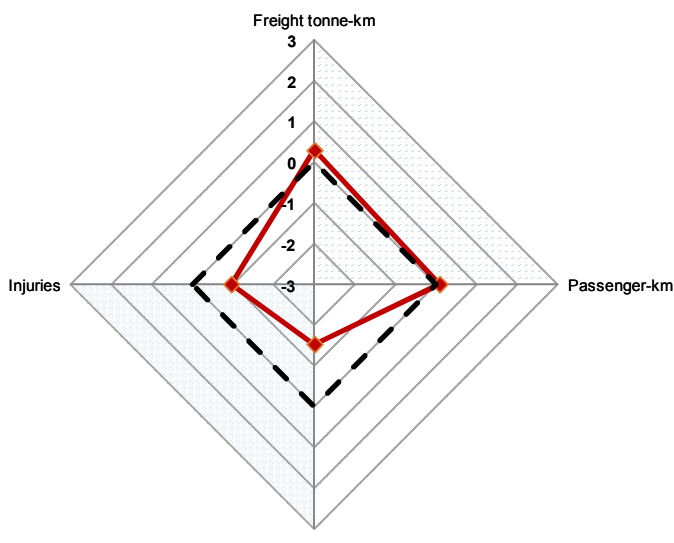

c02 emissions

Note: The dotted line represents the OECD average; the solid line represents the country shown. Indicators are presented in units of standard deviation. Data points greater than 3 standard deviations from the OECD average have been set to 3 in order to maintain a readable scale. Any point therefore touching the outer boundary should be considered "above 3". Injuries from road accidents and $\mathrm{CO}_{2}$ emissions are shown as the inverse of their values, so that countries lying outside the black dotted line have fewer injuries or $\mathrm{CO}_{2}$ emissions than the average, and countries within the black dotted line have more injuries or $\mathrm{CO}_{2}$ emissions than the OECD average. See Table A1.5 for detailed information on dates and sources by country.

Source: International Transport Forum; IEA, $\mathrm{CO}_{2}$ Emissions from Fuel Combustion (database). 
Figure A1.3. Road input indicators

Average 2001-10, scaled by real GDP in USD at 2005 PPP

Australia

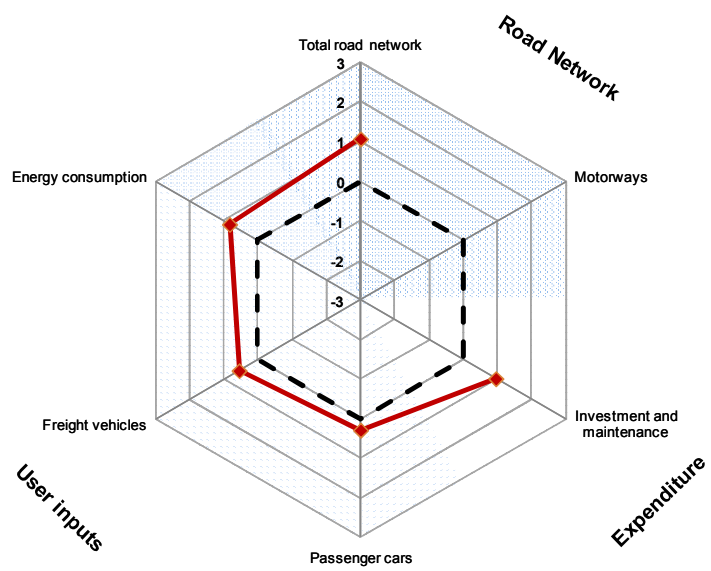

Belgium

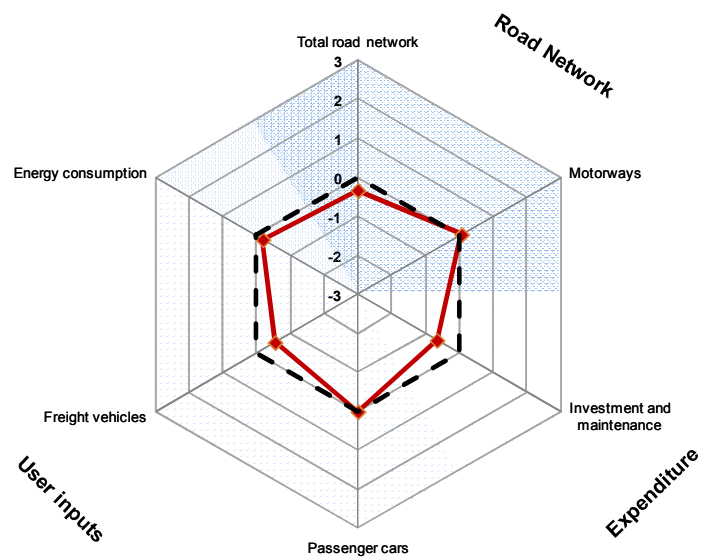

Chile

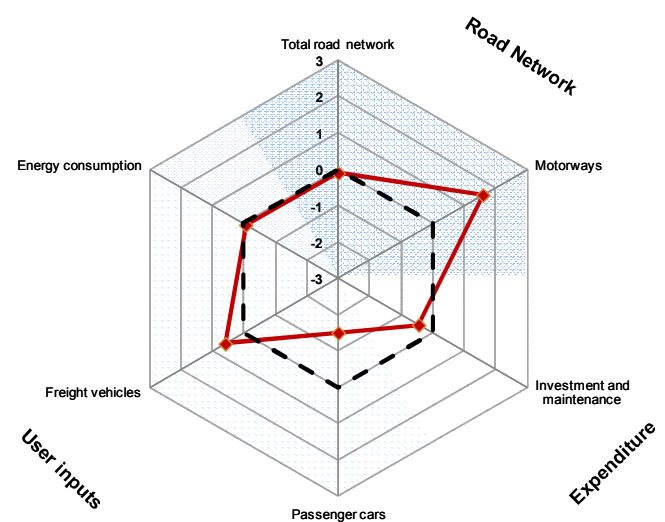

Austria

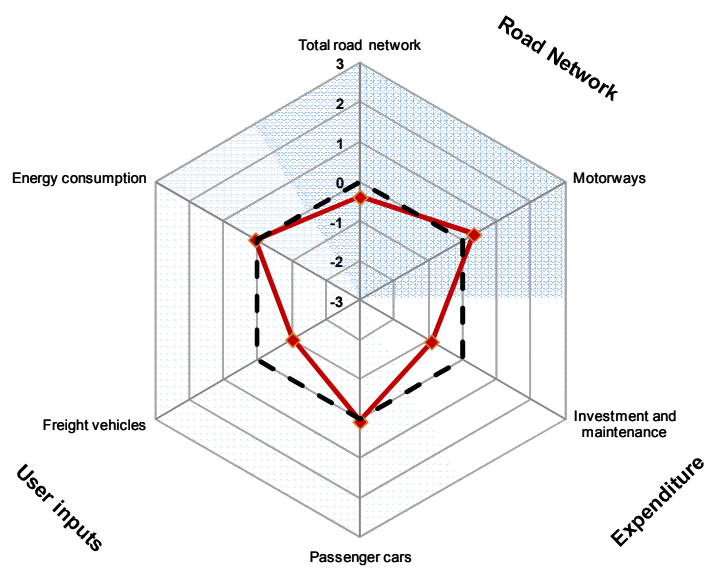

Canada

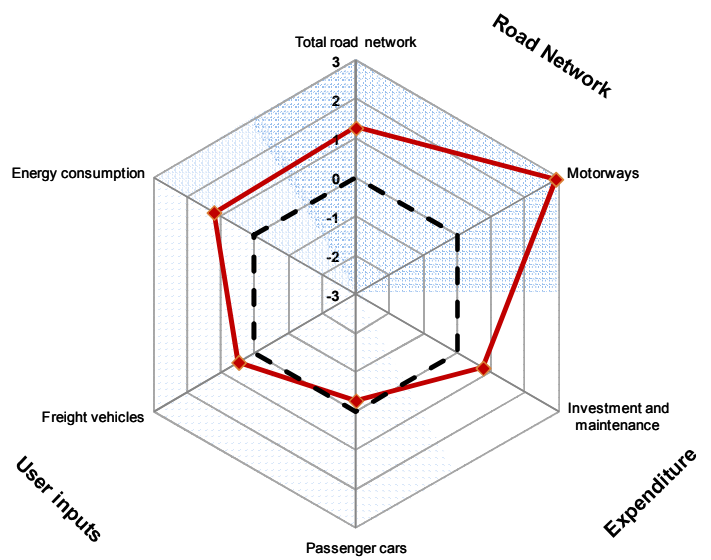

Czech Republic

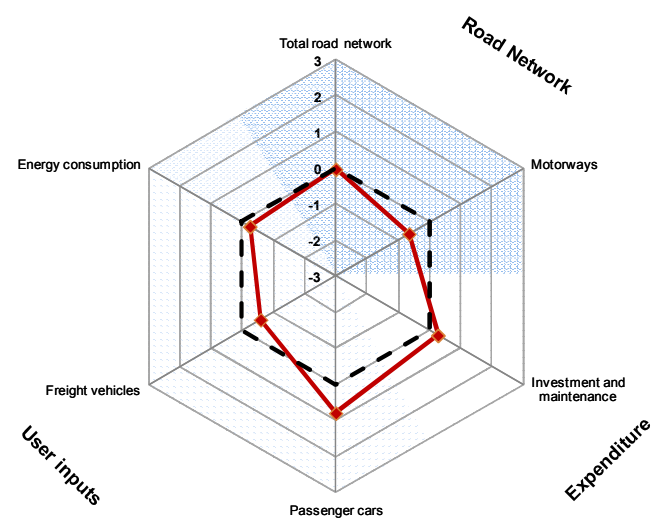


ECO/WKP(2013)8

Figure A1.3. Road input indicators (cont.)
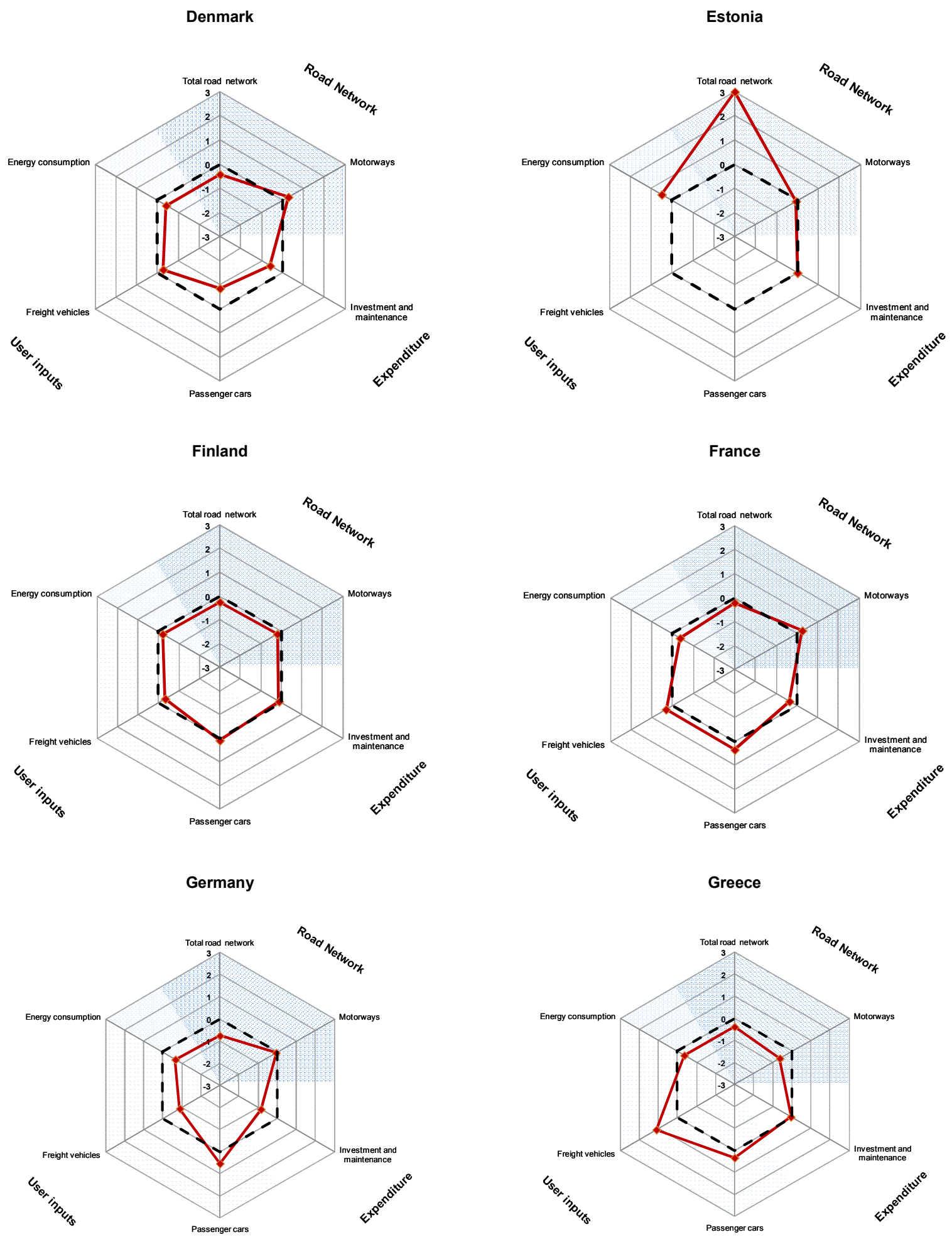
Figure A1.3. Road input indicators (cont.)
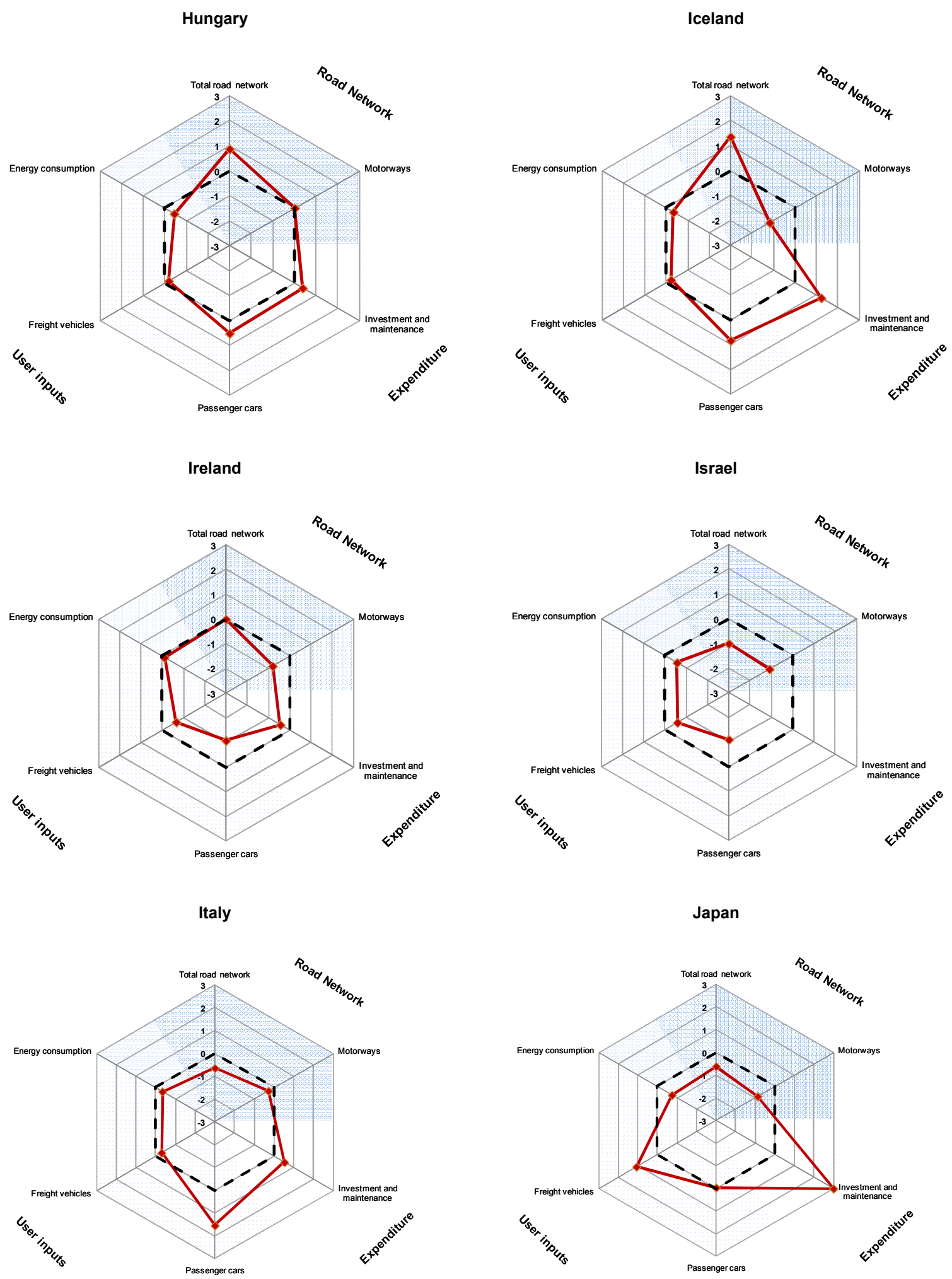
Figure A1.3. Road input indicators (cont.)

Korea

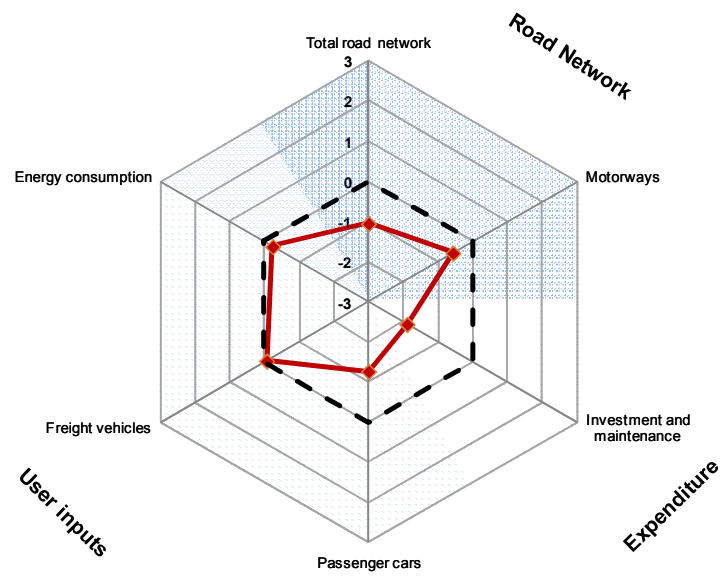

Mexico

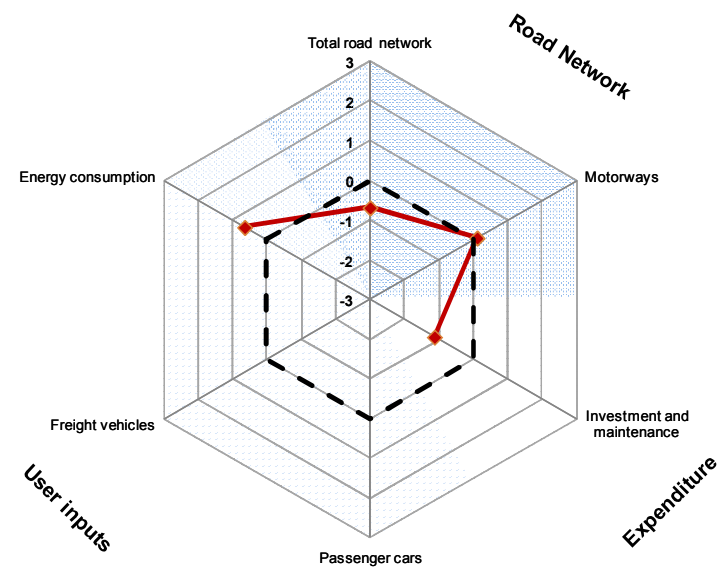

New Zealand

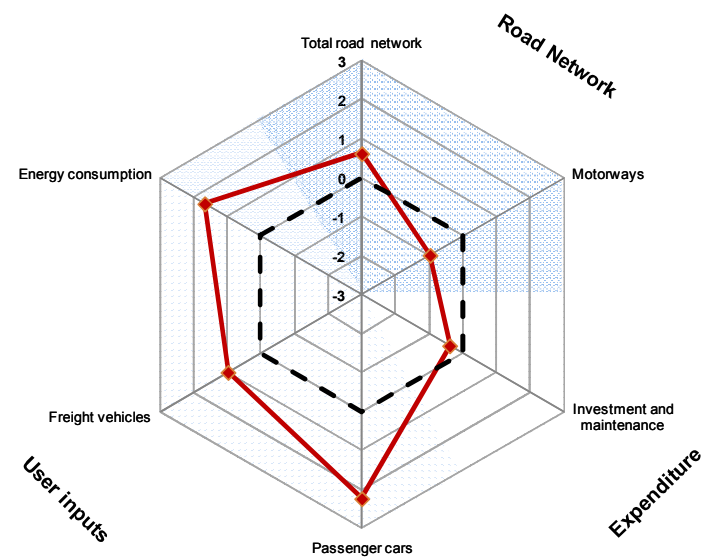

Luxembourg

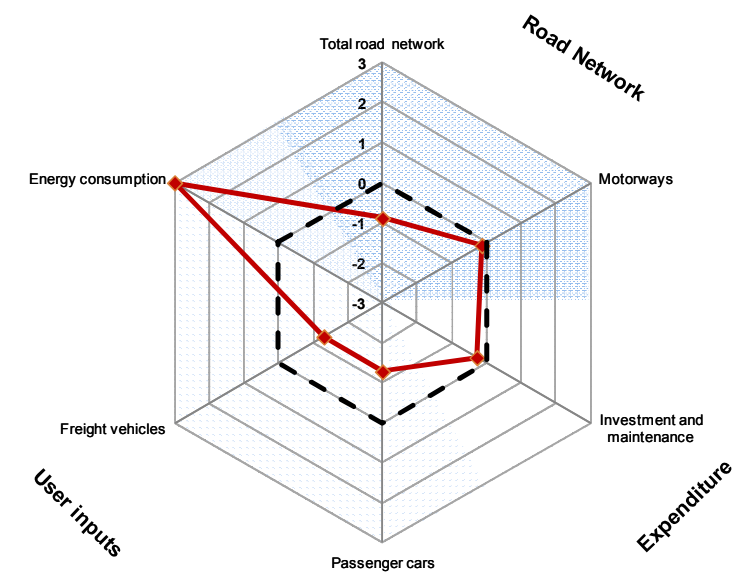

Netherlands

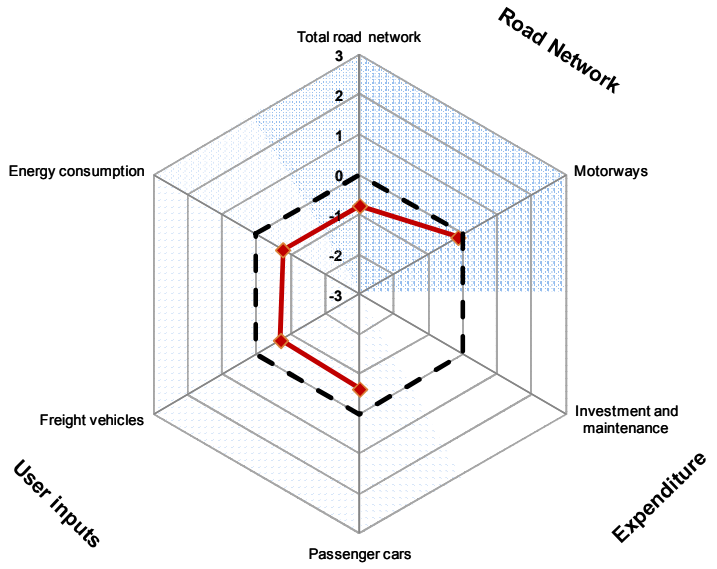

Norway

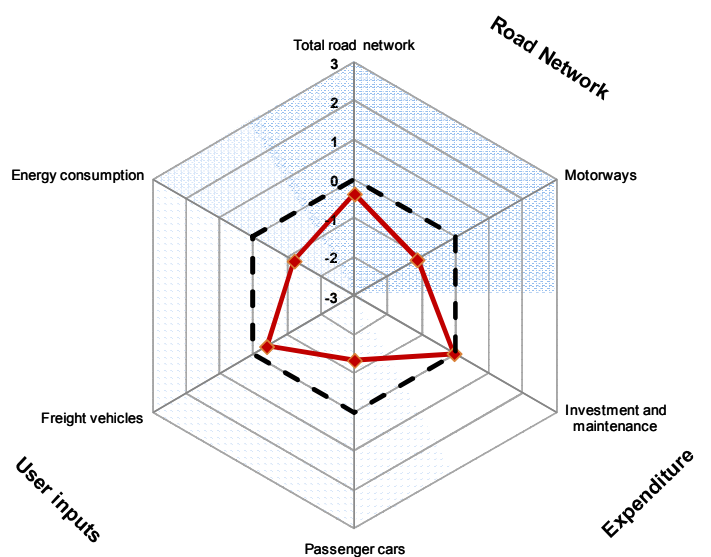



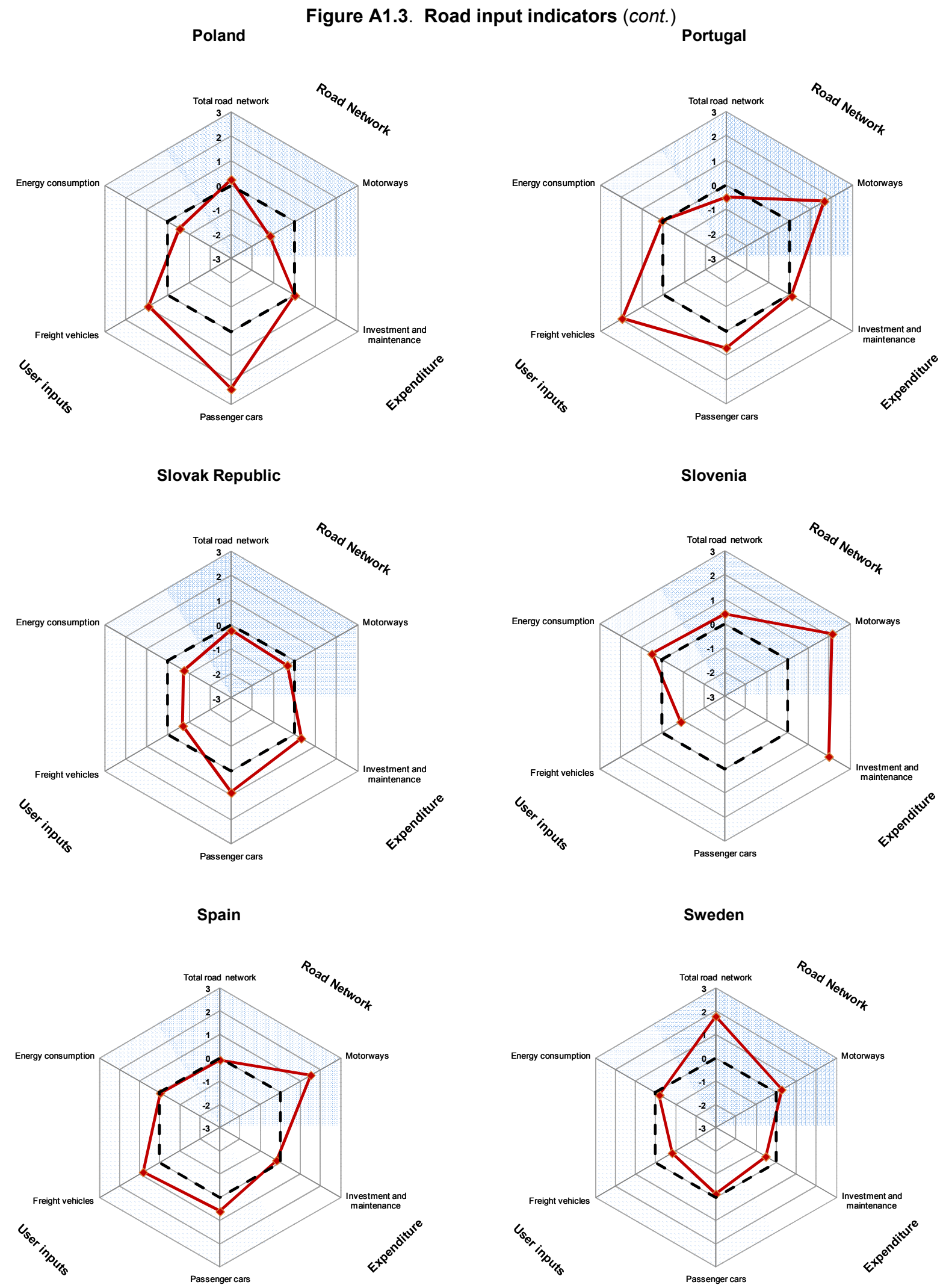
Figure A1.3. Road input indicators (cont.)

Switzerland

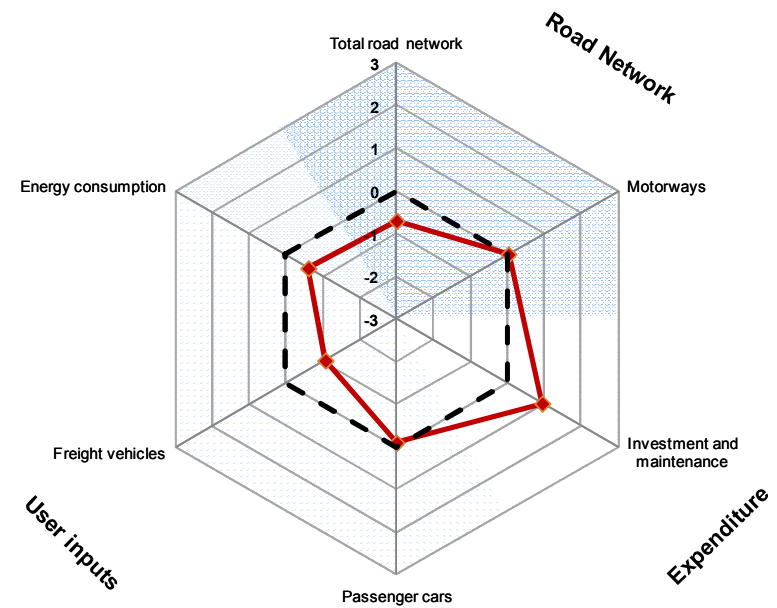

United Kingdom

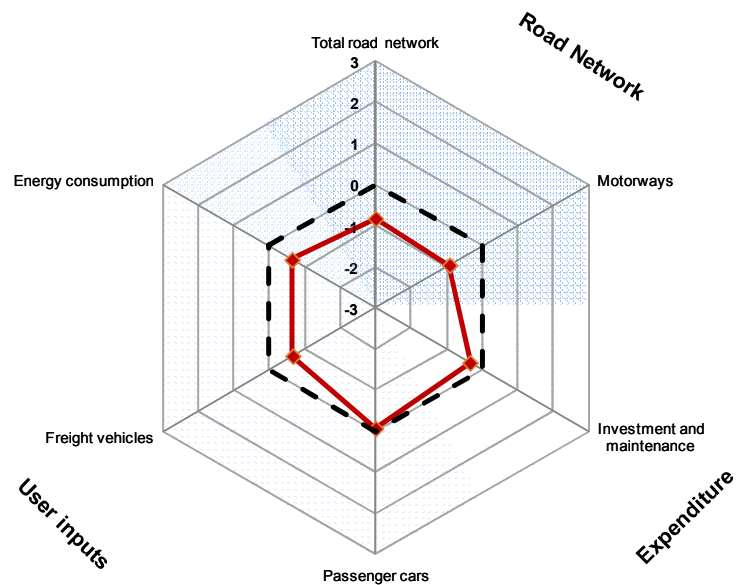

Turkey

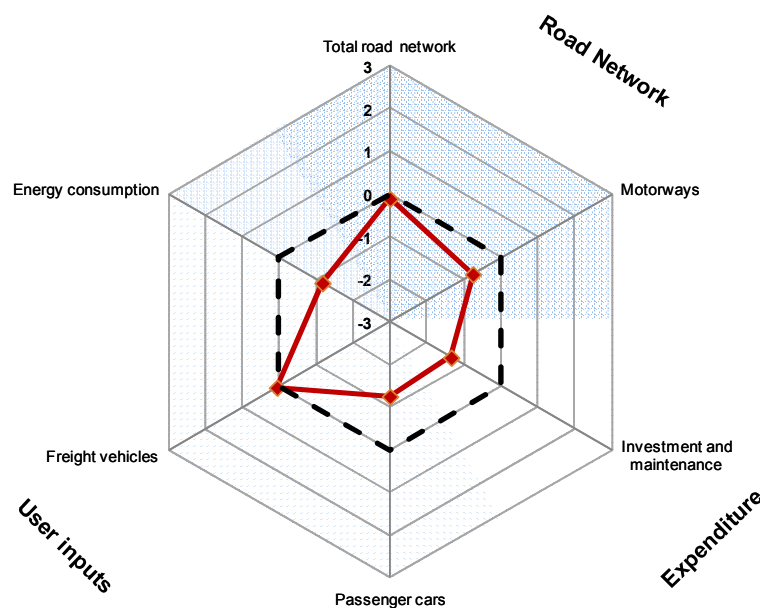

United States

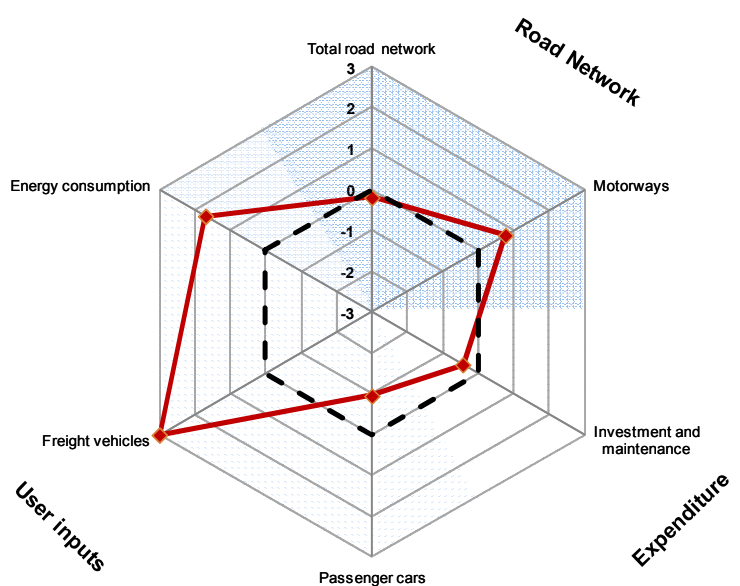

Note: The dotted line represents the OECD average, while the solid line represents the country shown. Data are scaled by real GDP and based on 2001-09 averages, except for investment and maintenance expenditures, which are based on nominal GDP ratios and 1992-2009 averages. The indicators are presented in units of standard deviation around the OECD average. Data points greater than 3 standard deviations from the OECD average have been set to 3 in order to maintain a readable scale. Any point touching the outer boundary should be considered "above 3". See Table A1.5 for detailed information on dates and sources by country.

Source: International Transport Forum; World Bank Development Indicators; IRTAD; and IRF World Road Statistics 2011. 


\section{BIBLIOGRAPHY}

Eurostat, Harmonised European Time Use Survey (HETUS).

Eurostat (2011a), Methodologies Used in Surveys of Road Freight Transport in Member States and Candidate Countries.

Eurostat (2011b), Road Freight Transport Methodology, Reference Manual for the Implementation of Council Regulation No. 1172/98.

Eurostat/ITF/UNECE (2009), Glossary for Transport Statistics.

INRIX (2010), National Traffic Scorecard.

International Energy Agency (IEA), $\mathrm{CO}_{2}$ Emissions from Fuel Combustion (database).

International Road Federation (IRF) (2011), World Road Statistics.

International Traffic Safety and Analysis Group (IRTAD), International Road Traffic and Accident Database.

International Transport Forum (ITF) (2012), Transport Outlook: Seamless Transport for Greener Growth, ITF/OECD.

Trafikverket (2010), Pocket Facts 2010, The Swedish Transport Administration, Borlange.

World Bank, World Bank Development Indicators (database). 
ECO/WKP(2013)8

\author{
APPENDIX 2 \\ Empirical methodology
}

This appendix discusses and compares the two methodologies that have been employed in this study to estimate the efficiency of the road transport sector: data envelopment analysis (DEA) and stochastic parametric frontier analysis. Overall, it is argued that DEA results are to be preferred to those of the stochastic frontier approach.

\title{
Data envelopment analysis
}

Data envelopment analysis (DEA) is a methodology to estimate efficiency, which accommodates multiple outputs and inputs. The main advantage compared to other methodologies to estimate efficiency, such as frontiers analysis (Aigner et al., 1977; Battese and Coelli, 1988) or corrected ordinary least squares (Aigner and Chu, 1968; Green, 2008), is that it is non-parametric and imposes weak restrictions on the production function. Previous OECD studies, notably on education (Sutherland et al., 2007) and health care (OECD, 2010), have employed this methodology to measure efficiency. Appendix 3 (Table A3.1) shows a selected number of studies that have used DEA or other techniques to estimate efficiency of different aspects of the transport system and their main results.

The potential efficiency gains for observational units depend on their distance from the frontier. Observational units (e.g. countries) lying on the efficiency frontier are unable to raise outputs without increasing inputs or equivalently they cannot reduce inputs without lowering outputs. Units below the frontier are inefficient and can thus increase outputs for given inputs or decrease inputs for given outputs. The larger the distance to the frontier, the larger the room for improvement. Traditionally, potential inefficiency has been defined in two ways (Figure A2.1): $i$ ) the proportional increase in output that can be achieved while holding inputs constant (output inefficiency); $i$ ) the proportional decrease in input that can be realised for the same level of outputs (input inefficiency).

This study mostly relies on a third approach, namely the directional distance function approach (Bogetoft and Otto, 2011), which makes it possible to gauge efficiency based on simultaneous changes in inputs and outputs that moves the inefficient unit to the frontier. Using this methodology, efficiency scores vary according to the direction used to measure the change in outputs and inputs (Figure A2.1). For a given unit, different directions produce different efficiency scores. This study, as many empirical studies having used the same methodology, sets the directional vector so as to obtain efficiency scores as a proportion of the current level of outputs and inputs. This involves equalising the two angles $\overline{Y^{*} E Y}$ and $\overline{E O X}$, thus making the two triangles $Y^{*} E Y$ and $E O Y$ proportional. Then the increase in output and decrease in inputs necessary to reach the frontier expressed as a proportion of the current levels of output and input - $\left(Y^{*}\right.$ $Y) / Y$ and $\left(X-X^{*} / X\right)$ respectively - will be the same and less than one. The efficiency index computed in this way is equivalent to the traditional Farrell efficiency index. The efficiency scores are expressed so as to vary from the lowest (zero) to the highest efficiency level (one). The potential percentage increase (decrease) in outputs (inputs) can be computed as one minus the efficiency score times 100.

Choosing the direction over which inputs or outputs are changed is an advantage over standard inputand output-oriented efficiency measures as it easily allows for treating some outputs and/or inputs as fixed. Output- and input-oriented efficiency scores are indeed specific cases of the directional distance approach. 
Input-oriented efficiency indices result from assuming output as fixed and therefore choosing a purely input-oriented direction. The converse is true for output-oriented efficiency measures.

All DEA models estimated in this study allow for variable returns to scale. In the absence of any prior information concerning returns to scale of the road transport sector variable returns to scale were chosen as it is less restrictive than constant returns to scale. Also, the use of variables in the form of ratios requires the adoption of variable return to scale to obtain reliable estimates (Hollingsworth and Smith, 2003). Returns-to-scale frontiers are modelled as a straight line from the origin (Figure A2.1). If a unit is efficient under constant return to scale it will be so under variable returns to scale but the opposite is not necessarily true.

DEA efficiency scores tend to be upward biased, especially when samples are small - as in this study - possibly wrongly identifying countries as efficient. The upward bias was corrected by adapting the bootstrapping technique developed by Simar and Wilson (1998) to the directional distance function approach. This technique also provides confidence intervals for the efficiency scores. Computing confidence intervals around DEA scores is important since estimates are sensitive to measurement errors, statistical noise and outliers. It should be emphasised that the reliability of an efficiency score depends on the density of observations in the region of the frontier where a country is located. Countries with atypical levels of inputs and outputs tend to be considered as efficient but this result is merely a consequence of the dearth of comparable observations.

Figure A2.1. The efficiency frontier and the measurement of potential efficiency gains

An illustration based on one output and one input production function

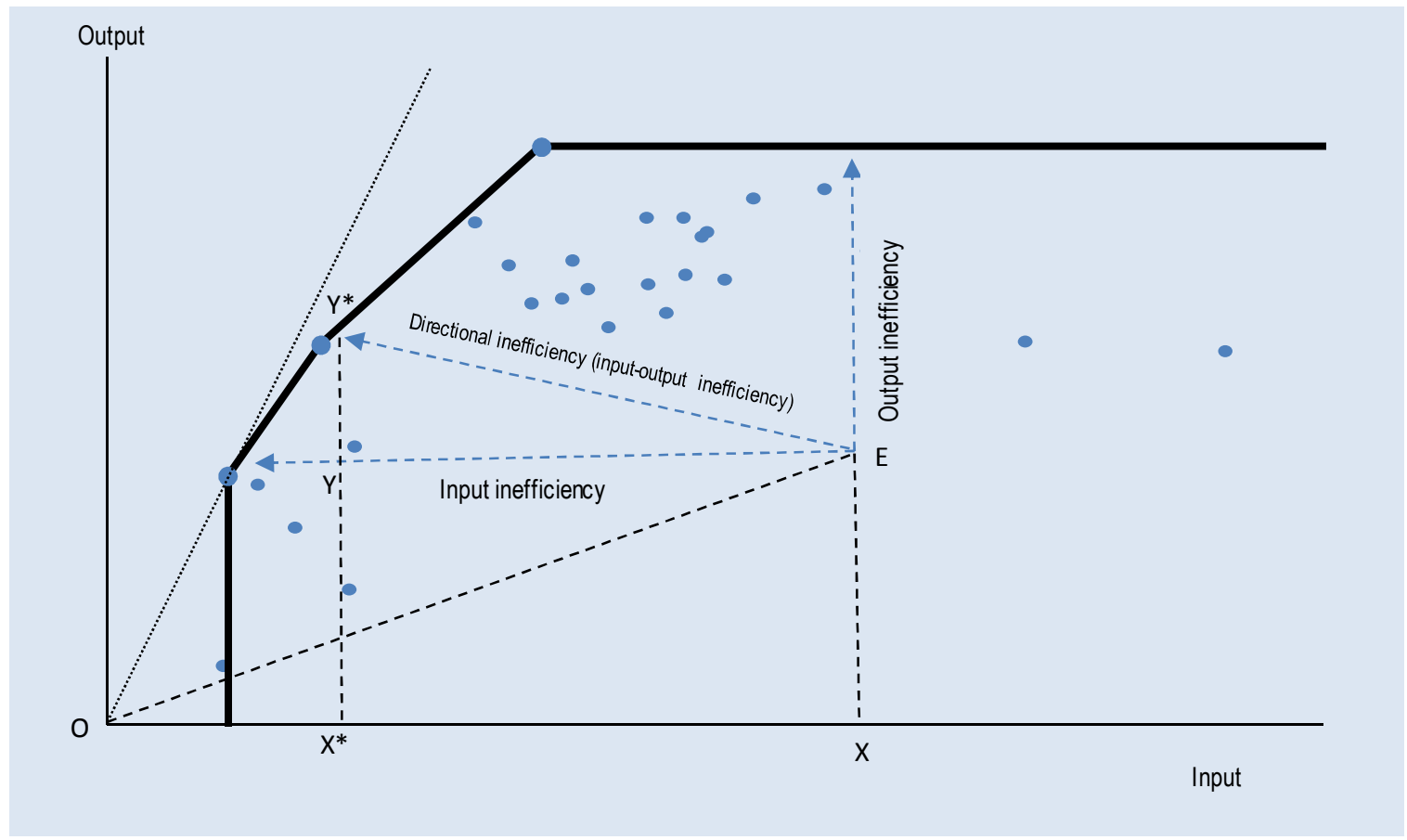

Note: The bold line is the efficiency frontier under variable returns to scale. The dotted line is the efficient frontier under constant return to scale. Potential efficiency gains can be defined as the amount by which an input could be reduced while holding constant the level of output (input-oriented inefficiency), the amount by which output could be increased while holding constant the level of input (output-oriented inefficiency) and the contemporaneous change in outputs and inputs (input-output-oriented or directional inefficiency). 
This study takes into account undesirable outputs. Dealing with undesirable outputs poses problems in efficiency analysis. The DEA literature has developed three methods to take them into account:

- Treating them as inputs;

- Transforming undesirable output data so that they can be treated as desirable outputs (Seiford and Zhu, 2002);

- Treating undesirable outputs as such by modelling the technological relationship with desirable outputs (Chung et al., 1997).

In this study, undesirable outputs, i.e. injuries, are treated as inputs. The rationale for this choice is that higher efficiency levels may result from either raising desirable outputs or reducing inputs and undesirable outputs. From this point of view inputs and undesirable outputs are equivalent (Liu et al., 2010) and DEA efficiency scores revolve around maximising what is "good" - i.e. desirable outputs - and minimising what is bad-i.e. inputs and undesirable outputs.

Transforming undesirable output data has the drawback that efficiency scores can be sensitive to the specific rule used to transform the data. The third approach is intellectually the most coherent. However, it assumes a precise technological relationship - called weak disposability - between desirable and undesirable outputs that is unlikely to hold for cross-country comparisons of the road transport sector. Weak disposability implies that that any reduction in undesirable outputs can be achieved only by reducing the desirable ones. This assumption is likely to hold in sectors, such as coal power generating plants, where the production technology is precisely defined. In this case, it is safe to assume that because of technological constraints, plants will be able to reduce emissions only by lowering electricity production. Reducing emissions then impose costs in terms of lost output. The relationship between injuries and traffic flows in the road transport sector is unlikely to face such constraints. Injuries depend on road conditions and safety measures that are not strictly connected with traffic flows. More importantly, less road accidents and therefore injuries may result in less congestion and therefore higher and not lower passenger and freight traffic flows, ceteris paribus.

\section{Parametric frontier analysis}

Efficiency can be estimated through stochastic production frontier analysis (Battese and Coelli, 1988). The drawback of this technique compared to DEA is that the relationship between inputs and an output is parametric and the estimated efficiency level will be biased if the functional form is incorrect. The main advantage is that it takes into account statistical noise in the relationship between inputs and an output. The estimated efficiency frontier will therefore not be biased upwards, as is the case for DEA. Therefore, in stochastic frontier analysis the relationship between inputs and an output is stochastic and parametric, whereas using DEA it is deterministic and non-parametric.

In the basic stochastic production function framework (Aigner, Lovell and Schmidt, 1977; Meeusen and van den Broeck, 1977) the log of output is modelled as a function of the log of inputs, a non-negative random error representing technical inefficiency, and a symmetric random error capturing statistical noise. The latter takes into account the effect of omitted variables, measurement and approximation errors associated with the choice of the functional relationship between inputs and output. The output-oriented technical efficiency level can be computed as the ratio of the observed level of output relative to the stochastic frontier. This measure is bounded between zero and one. Figure A2.2 depicts the noise and output-oriented inefficiency effect. 
Figure A2.2. The stochastic production frontier

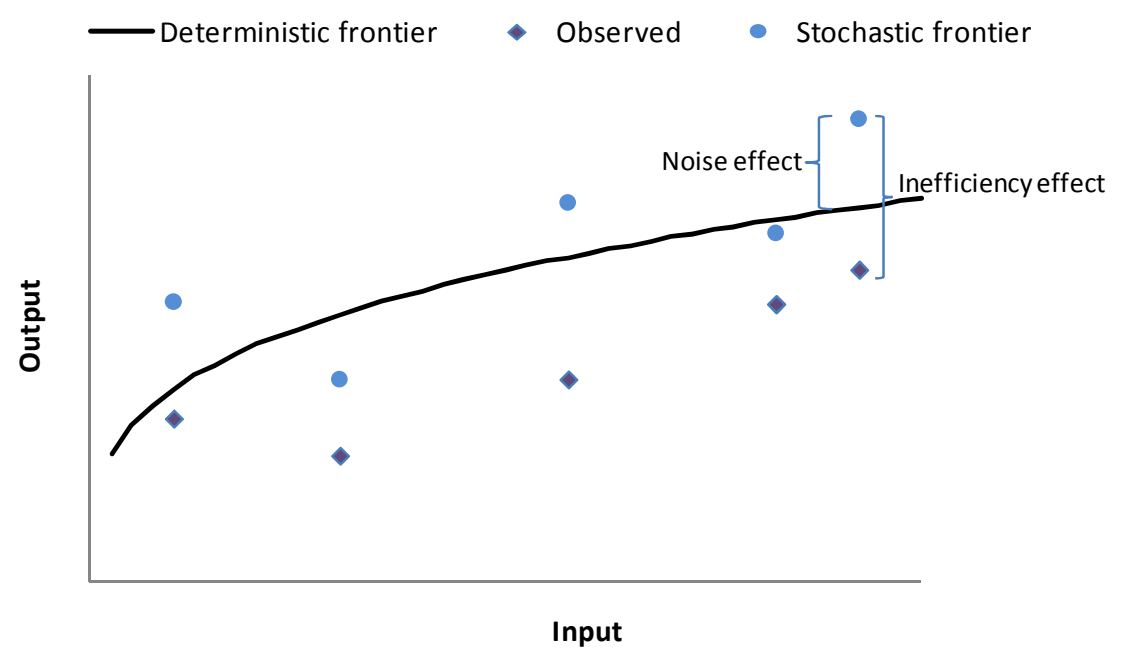

Note: Assuming one output and one input the deterministic frontier is generated by $y=x^{b}$, the stochastic frontier is $y=x^{b} e^{v}$ where $v$ is a symmetric statistical noise term; the observed value is then $y=x^{b} e^{v} e^{u}$ where $u$ is the inefficiency term assumed to be less than or equal to zero. The inefficiency effect is output oriented.

The basic production frontier approach cannot deal with multiple outputs. To overcome this problem, techniques have been developed to estimate input- or output-oriented distance functions. The output(input-) oriented distance function is an efficiency measure that gauges the maximum expansion (contraction) of outputs (inputs) keeping the level of inputs (outputs) constant. The distance function can be modelled as a function of inputs (y) and outputs (x) plus a statistical noise term.

$\ln d_{i}=\beta_{0}+\sum_{n} \delta_{n} \ln y_{n i}+\sum_{m} \beta_{m} \ln x_{m i}+\varepsilon_{i}$

However, these distance functions cannot be estimated directly, as the dependent variable - i.e. the distance (d) from the frontier - is the unobserved variable that needs to be measured. Exploiting some regularity conditions, namely homogeneity of degree one in inputs and outputs, distance functions can be re-written so as to be amenable to econometric estimation. ${ }^{31}$ This involves choosing one discretionary factor, i.e. one that is allowed to change, as the normalising variable. The other discretionary factors are scaled by the normalising variable, which is also the dependent variable. In this way, the distance from the frontier and the statistical noise term can then be modelled in the same way as in the stochastic production frontier approach (Coelli et al. 2005). As an example, in the case of the input distance function, assuming a Cobb-Douglas specification, the econometric specification is the following:

$$
-\ln x_{M i}=\beta_{0}+\sum_{n} \delta_{n} \ln y_{n i}+\sum_{m}^{M-1} \beta_{m} \ln x_{m i} / x_{M i}+\varepsilon_{i}-\ln d_{i}
$$

where $x_{M i}$ is the normalising factor, which exploits the homogeneity of degree one in inputs of the distance function (i.e. $\sum_{m} \beta_{m}=1$ ). To provide results comparable as much as possible to the baseline DEA model, an input-output oriented distance function is estimated. It accounts for the contemporaneous increase in outputs and reduction in inputs to reach the frontier (Cuesta and Zofio, 2005). Following

31. In empirical applications some regularity conditions that input distance functions should respect are often violated but can be imposed (O’Donnell and Coelli, 2005). See Coelli et al. (2005) for all the regularity conditions of distance functions. 
previous empirical studies, the distance function is modelled by means of the translog specification instead of the Cobb-Douglas function as it is more flexible. ${ }^{32}$

Estimation of distance functions relies on the same stochastic techniques developed for production frontier analysis. In this exercise, the distance function was estimated by means of Corrected Ordinary Least Square (COLS) (Aigner and Chu, 1968; Green, 2008). The maximum-likelihood method was not used (Battese and Coelli, 1988) due to convergence problems.

Overall, DEA results are to be preferred to COLS for the following reasons:

- Endogeneity problems are a source of concern for parametric frontiers as inputs and outputs are unlikely to be exogenous (Kumbhakar, 2011); endogeneity results in biased parameter estimates and therefore incorrect efficiency levels.

- Unlike DEA, COLS imposes constraints on the shape of the frontier that affect efficiency scores; the translog specification, although more flexible than the Cobb-Douglas, models the production frontier parametrically and therefore is less general than DEA.

32. The translog specification is more flexible than the Cobb-Douglas as it includes squared and cross-terms of inputs and outputs. It has the additional benefit of not imposing, unlike the Cobb-Douglas, any restrictive assumption on the elasticity of substitution among inputs and being concave in outputs. 


\section{BIBLIOGRAPHY}

Aigner, D.J. and S.F. Chu (1968), "On Estimating the Industry Production Function", The American Economic Review, Vol. 58, No. 4, pp. 826-839.

Aigner, D.J., C.A.K. Lovell, and P. Schmidt (1977), "Formulation and Estimation of Stochastic Frontier Production Function Models", Journal of Econometrics, Vol. 6, No. 1, pp. 21-37.

Battese, G.E. and T.J. Coelli (1988), "Prediction of Firm-Level Technical Efficiencies with a Generalised Frontier Production Function and Panel Data", Journal of Econometrics, Vol. 38, No. 3, pp. 387-399.

Bogetoft, P. and L. Otto (2011), "Benchmarking with DEA, SFA and R", in Operations Research and Management Science, Spinger International Series.

Chung, Y.H., R. Färe and S. Grosskopf (1997), "Productivity and Undesirable Outputs: A Directional Distance Function Approach”, Journal of Environmental Management, Vol. 51(3), pp. 229-240.

Coelli, T.J., P.D.S. Rao, C.J. O’Donnell and G.E. Battese (2005), An Introduction to Efficiency and Productivity Analysis, Springer.

Hollingsworth, B. and P. Smith (2003), "Use of Ratios in Data Envelopment Analysis", Applied Economics Letters, Vol. 10(11), pp. 733-735.

Kumbhakar, S.C. (2011), "Estimation of Multiple Output Production Functions", www.econ.gatech.edu/files/seminars/kumbhakar_spring12.pdf

Seiford, L.M. and J. Zhu (2002), "Modelling Undesirable Factors in Efficiency Evaluation", European Journal of Operational Research, Vol. 142(1), pp. 16-20.

Simar, L., and P.W. Wilson (1998), "Sensitivity analysis of Efficiency Scores: How to Bootstrap in Nonparametric Frontier Models", Management Science, pp. 49-61.

Sutherland, D., R. Price, I. Joumard, and C. Nicq (2007), "Performance Indicators for Public Spending Efficiency in Primary and Secondary Education", OECD Economics Department Working Papers, No. 546, OECD Publishing. 
ECO/WKP(2013)8

APPENDIX 3

Empirical estimates of road transport sector efficiency

\section{DEA estimates}

Studies on transport infrastructure performance

Table A3.1. Selected studies on transport infrastructure performance

\begin{tabular}{|c|c|c|c|c|}
\hline Authors & $\begin{array}{l}\text { Sample, coverage, } \\
\text { methods }\end{array}$ & $\begin{array}{c}\text { Outcomes or } \\
\text { outputs }\end{array}$ & $\begin{array}{l}\text { Main explanatory } \\
\text { variables / inputs }\end{array}$ & Main results \\
\hline \multicolumn{5}{|l|}{ Road transport } \\
\hline Bhagavath (2006) & $\begin{array}{l}44 \text { Indian State road } \\
\text { transport } \\
\text { undertakings, } \\
\text { DEA }\end{array}$ & $\begin{array}{l}\text { - Revenue per bus } \\
\text { per day }\end{array}$ & $\begin{array}{l}\text { - Fleet size, } \\
\text { average kms } \\
\text { travelled by } \\
\text { bus and cost } \\
\text { per bus }\end{array}$ & $\begin{array}{l}\text { Under the assumption of variable } \\
\text { returns to scale, buses could have } \\
\text { used } 11 \% \text { fewer resources to produce } \\
\text { the same amount of output. }\end{array}$ \\
\hline $\begin{array}{l}\text { McMullen and } \\
\text { Noh (2007) }\end{array}$ & $\begin{array}{l}43 \text { single mode US } \\
\text { bus transit agencies; } \\
\text { DEA based on } \\
\text { directional output } \\
\text { distance function } \\
\text { approach; undesirable } \\
\text { outputs taken into } \\
\text { account }\end{array}$ & $\begin{array}{l}\text { - Desirable outputs: } \\
\text { passenger and } \\
\text { vehicle-miles } \\
\text { - Undesirable } \\
\text { outputs: HC, CO } \\
\text { and NOx } \\
\text { emissions }\end{array}$ & $\begin{array}{l}\text { - Labour hours } \\
\text { - Fuel } \\
\text { consumption } \\
\text { (measured in } \\
\text { BTUs) } \\
\text { - Total vehicle } \\
\text { seats }\end{array}$ & $\begin{array}{l}\text { Considering undesirable outputs } \\
\text { increases the number of efficient } \\
\text { agencies from } 5 \text { to } 22 \text {. } \\
\text { The least productive agency has room } \\
\text { to increase passenger miles and } \\
\text { reduce emissions by } 53 \% \text {. } \\
\text { The opportunity cost of emission } \\
\text { regulation is calculated in terms of the } \\
\text { amount of passenger-miles given up to } \\
\text { satisfy the emission standards. For the } \\
\text { entire sample passenger miles could } \\
\text { be increased by } 12.3 \% \text { if firms did not } \\
\text { have to reduce emissions. }\end{array}$ \\
\hline $\begin{array}{l}\text { Yu and Fan } \\
(2006)\end{array}$ & $\begin{array}{l}\text { Taiwan multimode } \\
\text { bus companies; } \\
\text { DEA based on } \\
\text { directional output } \\
\text { distance function } \\
\text { approach; undesirable } \\
\text { outputs taken into } \\
\text { account }\end{array}$ & $\begin{array}{l}\text { Desirable outputs: } \\
\text { passenger-kms } \\
\text { and passengers } \\
\text { - Undesirable } \\
\text { outputs: accident } \\
\text { costs }\end{array}$ & $\begin{array}{l}\text { - Network } \\
\text { length } \\
\text { - Drivers } \\
\text { - Vehicles } \\
\text { - Fuel } \\
\text { - Long- and } \\
\text { short-haul } \\
\text { transport } \\
\text { demand }\end{array}$ & $\begin{array}{l}\text { Measures of cost effectiveness are } \\
\text { very sensitive to the approach used. }\end{array}$ \\
\hline $\begin{array}{l}\text { Weber and } \\
\text { Weber (2004) }\end{array}$ & $\begin{array}{l}\text { US trucking industry; } \\
48 \text { US states; } \\
1994-2000 . \\
\text { DEA based on } \\
\text { directional output } \\
\text { distance function } \\
\text { approach; undesirable } \\
\text { output taken into } \\
\text { account; Luenberger } \\
\text { productivity index } \\
\text { (i.e. modified version } \\
\text { of Malmquist index) to } \\
\text { study productivity } \\
\text { changes over time }\end{array}$ & $\begin{array}{l}\text { Desirable output: } \\
\text { Real income in the } \\
\text { trucking } \\
\text { warehousing } \\
\text { industry } \\
\text { - Undesirable } \\
\text { output: accidents } \\
\text { involving fatalities }\end{array}$ & $\begin{array}{l}\text { - Labour } \\
\text { - Fuel } \\
\text { - Trucks } \\
\text { - Maintenance } \\
\text { expenditure on } \\
\text { highways } \\
\text { - Miles of } \\
\text { interstate } \\
\text { roads } \\
\text { - Miles of } \\
\text { non-interstate } \\
\text { roads } \\
\text { - Miles of inter- } \\
\text { state highways } \\
\text { in adjoining } \\
\text { states }\end{array}$ & $\begin{array}{l}\text { When ignoring fatalities average } \\
\text { inefficiency is higher than when not } \\
\text { taking them into account and fewer } \\
\text { states operate at the frontier. } \\
\text { Efficiency increased over time. }\end{array}$ \\
\hline
\end{tabular}


Table A3.1. Selected studies on transport infrastructure performance (cont.)

\begin{tabular}{|c|c|c|c|c|}
\hline Authors & $\begin{array}{c}\text { Sample, coverage, } \\
\text { methods }\end{array}$ & $\begin{array}{c}\text { Outcomes or } \\
\text { outputs }\end{array}$ & $\begin{array}{l}\text { Main explanatory } \\
\text { variables / inputs }\end{array}$ & Main results \\
\hline \multicolumn{5}{|c|}{ Road transport (cont.) } \\
\hline $\begin{array}{l}\text { Krautzberger and } \\
\text { Wetzel (2011) }\end{array}$ & $\begin{array}{l}\text { Commercial transport } \\
\text { industry; } 16 \text { EU countries } \\
\text { plus Norway; 1995-2005 } \\
\text { (STAN database and EU } \\
\text { KLEMS) } \\
\text { DEA based on } \\
\text { directional output } \\
\text { distance function; } \\
\text { Luenberger productivity } \\
\text { index (i.e. modified } \\
\text { version of Malmquist } \\
\text { index) to study } \\
\text { productivity changes } \\
\text { over time }\end{array}$ & $\begin{array}{l}\text { - Desirable } \\
\text { output: } \\
\text { revenues } \\
\text { - Undesirable } \\
\text { output: } \mathrm{CO}_{2} \\
\text { emissions }\end{array}$ & $\begin{array}{l}\text { - Intermediate inputs } \\
\text { (energy, material, } \\
\text { services) } \\
\text { - Capital stock } \\
\text { - Number of } \\
\text { employees }\end{array}$ & $\begin{array}{l}\text { Without considering emissions, } \\
\text { productivity growth over the sample } \\
\text { period was negative; considering } \\
\text { emissions, on average there was no } \\
\text { change as countries undertook } \mathrm{CO}_{2} \\
\text { abatement activities; half of the countries } \\
\text { experienced positive productivity growth, } \\
\text { the other half negative productivity } \\
\text { growth. } \\
\text { The production frontier moved upwards } \\
\text { suggesting technological progress, but } \\
\text { on average technical efficiency } \\
\text { decreased indicating that countries on } \\
\text { average were not able to catch up with } \\
\text { best practice. }\end{array}$ \\
\hline Oh et al. (2011) & $\begin{array}{l}59 \text { bus agencies in } \\
\text { Seoul; 2003-05 } \\
\text { DEA with directional } \\
\text { output distance } \\
\text { function; undesirable } \\
\text { output taken into } \\
\text { account }\end{array}$ & $\begin{array}{l}\text { - Desirable } \\
\text { outputs: } \\
\text { vehicle- } \\
\text { kilometres and } \\
\text { passengers } \\
\text { - Undesirable } \\
\text { output: } \\
\text { emission costs }\end{array}$ & $\begin{array}{l}\text { - Drivers } \\
\text { - Mechanics, } \\
\text { administration- } \\
\text { related staff } \\
\text { - Number of buses } \\
\text { - Fuel costs }\end{array}$ & $\begin{array}{l}\text { The number of efficient agencies and the } \\
\text { efficiency score rankings differed } \\
\text { depending on whether or not emissions } \\
\text { were considered. On average, inefficient } \\
\text { agencies have the room to increase the } \\
\text { desirable output and decrease the } \\
\text { undesirable one by around } 5 \% \text {. } \\
\text { Agencies operating bus routes that were } \\
\text { tendered were more efficient than those } \\
\text { operating routes that were not. }\end{array}$ \\
\hline \multicolumn{5}{|l|}{ Train transport } \\
\hline $\begin{array}{l}\text { Coelli and } \\
\text { Perelman (1999) }\end{array}$ & $\begin{array}{l}17 \text { European railway } \\
\text { companies over the } \\
\text { period 1988-93 } \\
\text { (International Union of } \\
\text { Railways data). } \\
\text { DEA, corrected } \\
\text { ordinary least squares, } \\
\text { parametric frontier } \\
\text { using linear } \\
\text { programming. }\end{array}$ & $\begin{array}{l}\text { Passenger } \\
\text { services (sum } \\
\text { of distance } \\
\text { travelled by } \\
\text { each } \\
\text { passenger) } \\
\text { - Freight services } \\
\text { (sum of } \\
\text { distance } \\
\text { travelled by } \\
\text { each tonne of } \\
\text { freight) }\end{array}$ & $\begin{array}{l}\text { - Staff involved in } \\
\text { train and station } \\
\text { services } \\
\text { - Rolling stock } \\
\text { (available freight } \\
\text { wagons and coach } \\
\text { transport capacities } \\
\text { in tonnes and seats) } \\
\text { - Total length of lines }\end{array}$ & $\begin{array}{l}\text { The three estimation methods reach } \\
\text { similar conclusions on the relative } \\
\text { efficiency of the } 17 \text { railways companies. }\end{array}$ \\
\hline $\begin{array}{l}\text { O'Donnell and } \\
\text { Coelli (2005) }\end{array}$ & $\begin{array}{l}17 \text { European railways } \\
\text { companies over the } \\
\text { period 1988-93 } \\
\text { (International Union of } \\
\text { Railways data). } \\
\text { Estimation of an output } \\
\text { distance function } \\
\text { through Bayesian } \\
\text { stochastic frontier. }\end{array}$ & $\begin{array}{l}\text { Passenger } \\
\text { services (sum } \\
\text { of distance } \\
\text { travelled by } \\
\text { each } \\
\text { passenger) } \\
\text { - Freight services } \\
\text { (sum of } \\
\text { distance } \\
\text { travelled by } \\
\text { each tonne of } \\
\text { freight) }\end{array}$ & $\begin{array}{l}\text { - Staff involved in } \\
\text { train and station } \\
\text { services } \\
\text { - Rolling stock } \\
\text { (available freight } \\
\text { wagons and coach } \\
\text { transport capacity in } \\
\text { tonnes and seats) } \\
\text { - Total length of lines }\end{array}$ & $\begin{array}{l}\text { Bayesian estimation method enables to } \\
\text { impose theoretically consistent } \\
\text { regulatory conditions on the output } \\
\text { distance function; without them results } \\
\text { from output distance functions may be } \\
\text { implausible. } \\
\text { Overall estimated technical inefficiency } \\
\text { levels are sensitive to such constraints } \\
\text { in addition to random or fixed effects } \\
\text { assumptions. }\end{array}$ \\
\hline $\begin{array}{l}\text { Fukuyama et al. } \\
\text { (2011) }\end{array}$ & $\begin{array}{l}\text { Japanese railway } \\
\text { companies and the } \\
\text { aviation sector; 1999- } \\
2007 . \text { Slack-based } \\
\text { inefficiency index, } \\
\text { taking into account } \\
\text { undesirable outputs } \\
\text { (efficiency measures } \\
\text { are based on the } \\
\text { potential increase in } \\
\text { desirable outputs, and } \\
\text { decrease in the } \\
\text { undesirable ones and } \\
\text { inputs) }\end{array}$ & $\begin{array}{l}\text { Desirable } \\
\text { output: work } \\
\text { load unit } \\
\text { (enabling the } \\
\text { comparison of } \\
\text { the levels of } \\
\text { activity of } \\
\text { different travel } \\
\text { modes) } \\
\text { - Undesirable } \\
\text { output: C02 } \\
\text { emissions }\end{array}$ & $\begin{array}{l}\text { - Labour (persons) } \\
\text { - Capital } \\
\text { - Users' time cost } \\
\text { (vehicle time) } \\
\text { - Other variable } \\
\text { inputs }\end{array}$ & $\begin{array}{l}\text { Overall air transport is more } \\
\text { environmentally efficient than rail } \\
\text { transport. This is mainly because of the } \\
\text { higher speed of air transport resulting in } \\
\text { shorter time spent on travel and } \\
\text { therefore lower user cost. }\end{array}$ \\
\hline
\end{tabular}


ECO/WKP(2013)8

Table A3.1. Selected studies on transport infrastructure performance (cont.)

\begin{tabular}{|c|c|c|c|c|}
\hline Authors & $\begin{array}{c}\text { Sample, coverage, } \\
\text { methods }\end{array}$ & Outcomes or outputs & $\begin{array}{l}\text { Main explanatory } \\
\text { variables / inputs }\end{array}$ & Main results \\
\hline \multicolumn{5}{|l|}{ Air transport } \\
\hline Yu (2004) & $\begin{array}{l}\text { 14 Taiwanese } \\
\text { domestic airports; } \\
\text { 1994-2000 period } \\
\text { DEA; output-oriented } \\
\text { directional function } \\
\text { so as to deal with } \\
\text { non-desirable } \\
\text { outputs, constant } \\
\text { returns to scale }\end{array}$ & $\begin{array}{l}\text { Desirable outputs: } \\
\text { number of aircraft } \\
\text { traffic movements; } \\
\text { number of } \\
\text { passengers } \\
\text { - Undesirable output: } \\
\text { noise }\end{array}$ & $\begin{array}{l}\text { - Runaway area } \\
\text { - Apron area } \\
\text { - Terminal area } \\
\text { - Routes } \\
\text { - County population } \\
\text { (as environmental } \\
\text { non-discretionary } \\
\text { input) }\end{array}$ & $\begin{array}{l}\text { Accounting for the environmental } \\
\text { factor and especially the undesirable } \\
\text { output affects greatly efficiency } \\
\text { scores; they are in general larger } \\
\text { than those computed without } \\
\text { accounting for the undesirable } \\
\text { output and the environmental factor. }\end{array}$ \\
\hline $\begin{array}{l}\text { Pathomsiri et al. } \\
\text { (2008) }\end{array}$ & $\begin{array}{l}56 \text { US airports; } \\
2000-03 ; \\
\text { DEA; output-oriented } \\
\text { directional function } \\
\text { so as to deal with } \\
\text { non-desirable } \\
\text { outputs; constant } \\
\text { returns to scale. }\end{array}$ & $\begin{array}{l}\text { - Desirable outputs: } \\
\text { non-delayed flights; } \\
\text { number of } \\
\text { passengers; cargo } \\
\text { throughput } \\
\text { - Undesirable output: } \\
\text { delayed-flights; time } \\
\text { delays }\end{array}$ & $\begin{array}{l}\text { - Land area } \\
\text { - Number of } \\
\text { runways } \\
\text { - Runway area }\end{array}$ & $\begin{array}{l}\text { Without considering delays, efficient } \\
\text { airports are generally the very } \\
\text { congested ones; including delays } \\
\text { more airports are efficient as } \\
\text { less-busy and uncongested ones } \\
\text { move closer to the frontier; } \\
\text { considering delays also results in } \\
\text { slower productivity growth. }\end{array}$ \\
\hline $\begin{array}{l}\text { Lozano and } \\
\text { Gutiérrez (2010) }\end{array}$ & $\begin{array}{l}39 \text { Spanish airports; } \\
\text { 2006-07 } \\
\text { DEA; Slack Based } \\
\text { Measure (SBM), } \\
\text { accounting for } \\
\text { undesirable outputs } \\
\text { and with non- } \\
\text { discretionary inputs. }\end{array}$ & $\begin{array}{l}\text { - Desirable outputs: } \\
\text { aircraft traffic } \\
\text { movements, } \\
\text { passenger } \\
\text { movements and cargo } \\
\text { handled } \\
\text { - Undesirable outputs: } \\
\text { percentage of delayed } \\
\text { flights and average } \\
\text { delay of delayed } \\
\text { flights }\end{array}$ & $\begin{array}{l}\text { - Runway area } \\
\text { - Apron capacity } \\
\text { - Number of } \\
\text { baggage belts } \\
\text { - Number of } \\
\text { check-in counters } \\
\text { - Number of } \\
\text { boarding gates }\end{array}$ & $\begin{array}{l}\text { Disregarding the undesirable outputs } \\
\text { results generally in higher efficiency } \\
\text { measures except for a few cases. } \\
\text { Considering undesirable outputs, } \\
\text { many airports are found to be } \\
\text { technically efficient, but the } \\
\text { efficiency score of inefficient airports } \\
\text { is very low. Among desirable } \\
\text { outputs, cargo handling is the output } \\
\text { inefficient airports could increase the } \\
\text { most; among undesirable outputs, } \\
\text { there is substantial room to reduce } \\
\text { the percentage of delayed flights. } \\
\text { The SBM results are similar to those } \\
\text { obtained with the output-oriented } \\
\text { directional function approach. }\end{array}$ \\
\hline \multicolumn{5}{|l|}{ Ports } \\
\hline $\begin{array}{l}\text { Chin and Low } \\
(2010)\end{array}$ & $\begin{array}{l}156 \text { origin-destination } \\
\text { routes for } 13 \text { ports in } \\
\text { Asia; } \\
\text { DEA; Slack Based } \\
\text { Measure (SBM), } \\
\text { accounting for } \\
\text { undesirable outputs }\end{array}$ & $\begin{array}{l}\text { - Desirable output: } \\
\text { annual container } \\
\text { capacity flows } \\
\text { - Undesirable output: } \\
\text { atmospheric } \\
\text { emissions }\end{array}$ & $\begin{array}{l}\text { - Frequency of } \\
\text { shipping services } \\
\text { - Bilateral trade } \\
\text { flows }\end{array}$ & $\begin{array}{l}\text { Accounting for undesirable output } \\
\text { changes efficiency scores; the } \\
\text { optimum amount of shipping } \\
\text { capacity falls when undesirable } \\
\text { outputs are considered. }\end{array}$ \\
\hline $\begin{array}{l}\text { Estache, Tovar } \\
\text { and Trujillo } \\
(2004)\end{array}$ & $\begin{array}{l}11 \text { main Mexican } \\
\text { ports; } 1996-99 \text { (a } \\
\text { major regulatory } \\
\text { change preceded this } \\
\text { period); } \\
\text { DEA with variable } \\
\text { returns to scale and } \\
\text { Malmquist } \\
\text { productivity index. }\end{array}$ & $\begin{array}{l}\text { - Tons of merchandise } \\
\text { handled }\end{array}$ & $\begin{array}{l}\text { - Capital: length of } \\
\text { docks under } \\
\text { concession at } \\
\text { each port } \\
\text { - Labour: number of } \\
\text { workers }\end{array}$ & $\begin{array}{l}\text { Results using the Malmquist index } \\
\text { suggest that yearly TFP growth } \\
\text { averaged } 4.1 \% \text { during the period. } \\
\text { Technological change (i.e. upward } \\
\text { shift of the production frontier) } \\
\text { contributed around } 60 \% \text { of TFP } \\
\text { growth. The rest was due to } \\
\text { improvements in technical efficiency. } \\
\text { The decomposition of technical } \\
\text { efficiency into a pure technical } \\
\text { efficiency effect and a scale } \\
\text { economy effect shows that the } \\
\text { former increased in all but one port } \\
\text { and that scale economies rose on } \\
\text { average but with large differences } \\
\text { across ports. }\end{array}$ \\
\hline \multicolumn{5}{|l|}{ Parking lots } \\
\hline $\begin{array}{l}\text { Barnum, McNeil } \\
\text { and Hart (2007) }\end{array}$ & $\begin{array}{l}\text { Chicago Transit } \\
\text { Authority park-and-ride } \\
\text { lots (17 units), DEA. }\end{array}$ & $\begin{array}{l}\text { - Number of parked } \\
\text { cars } \\
\text { - Parking revenues }\end{array}$ & $\begin{array}{l}\text { - Number of parking } \\
\text { spaces } \\
\text { - Operating expenses }\end{array}$ & $\begin{array}{l}\text { They run a two-stage DEA to } \\
\text { account for environmental factors. }\end{array}$ \\
\hline
\end{tabular}




\section{Comparison of DEA models}

Table A3.2 presents DEA efficiency scores and their 95\% confidence interval estimated via bootstrapping for different models. Three models are considered to assess how adding inputs and outputs progressively affects country rankings. The first model (column one) uses the number of motor vehicles and the length of the road network as inputs, which are treated as fixed, and passenger and freight traffic as outputs. In column two, energy consumption is added as a variable input and column three also includes injuries as an undesirable output. The model in column three is the baseline model reported in Figure 4.1 of the main paper.

Overall, the country rankings of the different models are similar. The rank correlation coefficient between the models in column three and column one is 0.80 and between model three and model two is 0.90 . Only few countries experience large changes in ranking. Ireland moves from the top half to the bottom half of the efficiency scores' distribution whereas Australia moves from the top to the middle. The relative position of France, on the contrary, improves as it rises from the bottom half to the top half of the distribution. However, given the efficiency scores' large confidence intervals some of these changes could be attributed to noise. 
Table A3.2. DEA efficiency scores of alternative models

\begin{tabular}{|c|c|c|c|c|c|c|}
\hline & \multicolumn{2}{|c|}{$\begin{array}{c}\text { mkpf } \\
(1)\end{array}$} & \multicolumn{2}{|c|}{$\begin{array}{c}\text { mkepf } \\
(2)\end{array}$} & \multicolumn{2}{|c|}{$\begin{array}{c}\text { mkeipf } \\
\text { (3) }\end{array}$} \\
\hline AUS & \multicolumn{2}{|c|}{0.93} & \multicolumn{2}{|c|}{0.98} & \multicolumn{2}{|c|}{0.96} \\
\hline & $(0.47$ & $1.00)$ & $(0.87$ & $1.00)$ & $(0.78$ & 1.00) \\
\hline AUT & \multicolumn{2}{|c|}{0.92} & \multicolumn{2}{|c|}{0.96} & \multicolumn{2}{|c|}{0.97} \\
\hline & $(0.44$ & $1.00)$ & $(0.80$ & $1.00)$ & $(0.80$ & 1.00) \\
\hline BEL & \multicolumn{2}{|c|}{0.80} & \multicolumn{2}{|c|}{0.88} & \multicolumn{2}{|c|}{0.89} \\
\hline & (0.41 & 0.87) & (0.72 & 0.91) & $(0.73$ & 0.91) \\
\hline CAN & \multicolumn{2}{|c|}{0.92} & & & & \\
\hline & $(0.45$ & $1.00)$ & $(0.79$ & $1.00)$ & $(0.80$ & 1.00) \\
\hline $\mathrm{CHE}$ & & & & & & \\
\hline & $(0.39$ & $0.79)$ & $(0.75$ & $0.91)$ & $(0.77$ & $0.93)$ \\
\hline CZE & & & & & & \\
\hline & $(0.44$ & $0.91)$ & $(0.77$ & $0.90)$ & $(0.77$ & $0.90)$ \\
\hline DEU & & & & & & \\
\hline & $(0.44$ & $1.00)$ & $(0.82$ & $1.00)$ & $(0.83$ & 1.00) \\
\hline DNK & & & & & & \\
\hline & $(0.42$ & $1.00)$ & $(0.73$ & $1.00)$ & $(0.71$ & $1.00)$ \\
\hline ESP & & & & & & \\
\hline & $(0.42$ & $0.80)$ & $(0.66$ & $0.77)$ & $(0.71$ & $0.81)$ \\
\hline EST & & & & & & \\
\hline & $(0.50$ & $1.00)$ & $(0.67$ & $1.00)$ & $(0.67$ & 1.00) \\
\hline FIN & & & & & & \\
\hline & $(0.44$ & $1.00)$ & $(0.78$ & $1.00)$ & $(0.76$ & 1.00) \\
\hline FRA & & & & & & \\
\hline & $(0.42$ & $0.89)$ & $(0.84$ & $0.97)$ & $(0.88$ & 1.00) \\
\hline GBR & & & & & & \\
\hline & $(0.42$ & $1.00)$ & (0.69 & $1.00)$ & $(0.69$ & 1.00) \\
\hline GRC & & & & & & \\
\hline & $(0.27$ & $0.39)$ & $(0.56$ & $0.67)$ & $(0.56$ & $0.67)$ \\
\hline HUN & & & & & & \\
\hline & $(0.44$ & $0.90)$ & $(0.80$ & $0.94)$ & $(0.80$ & $0.94)$ \\
\hline IRL & & & & & & \\
\hline & $(0.42$ & 1.00) & $(0.78$ & 1.00) & $(0.72$ & 1.00) \\
\hline ISL & & & & & & \\
\hline & $(0.47$ & 1.00) & $(0.83$ & 1.00) & $(0.83$ & 1.00) \\
\hline ITA & & & & & & \\
\hline & $(0.46$ & 1.00) & $(0.76$ & 1.00) & $(0.76$ & 1.00) \\
\hline JPN & & & & & & \\
\hline & $(0.35$ & $0.63)$ & (0.85 & 0.93) & (0.85 & 0.93) \\
\hline KOR & & & & & & \\
\hline & (0.39 & 1.00) & (0.67 & 1.00) & $(0.68$ & 1.00) \\
\hline LUX & & & & & & \\
\hline & $(0.39$ & 1.00) & (0.67 & 1.00) & $(0.67$ & 1.00) \\
\hline MEX & & & & & & \\
\hline & $(0.42$ & 1.00) & $(0.75$ & 1.00) & (0.67 & 1.00) \\
\hline NLD & & & & & & \\
\hline & $(0.41$ & 1.00) & (0.68 & 1.00) & $(0.67$ & 1.00) \\
\hline NOR & & & & & & \\
\hline & (0.39 & $0.87)$ & $(0.74$ & 1.00) & $(0.68$ & 1.00) \\
\hline NZL & & & & & & \\
\hline & $(0.49$ & 1.00) & (0.83 & 1.00) & (0.83 & 1.00) \\
\hline POL & & & & & & \\
\hline & $(0.49$ & 1.00) & (0.88 & 1.00) & $(0.88$ & 1.00) \\
\hline PRT & & & & & & \\
\hline & $(0.41$ & $0.81)$ & (0.69 & $0.83)$ & $(0.69$ & $0.83)$ \\
\hline SVK & & & & & & \\
\hline & $(0.45$ & 1.00) & $(0.77$ & 1.00) & $(0.77$ & 1.00) \\
\hline SVN & & & & & & \\
\hline & $(0.47$ & 1.00) & $(0.79$ & 1.00) & $(0.80$ & 1.00) \\
\hline SWE & & & & & & \\
\hline & $(0.41$ & $0.84)$ & $(0.70$ & $0.87)$ & $(0.72$ & $0.88)$ \\
\hline TUR & & & & & 0 & \\
\hline & $(0.39$ & 1.00) & $(0.67$ & 1.00) & $(0.68$ & 1.00) \\
\hline USA & & & & & & \\
\hline & $(0.41$ & $0.83)$ & $(0.61$ & $0.79)$ & $(0.61$ & $0.79)$ \\
\hline
\end{tabular}

Note: Efficiency scores vary from zero to one, one being for the most efficient units; the 95\% confidence interval estimated via bootstrapping is in parentheses; the model in column one (mkpf) includes motor vehicles and kilometres of the road network as inputs, and passenger and freight traffic as outputs; the model mkepf uses energy consumption as an additional input; mkeipf is the base model presented in Figure 4.1, which includes also road injuries.

Source: ITF and OECD calculations. 


\section{Efficiency estimates by parametric stochastic frontier analysis}

Table A3.3 shows the average efficiency estimates for the 2000s obtained through pooled panel and fixed effects models and using the same variables as for the baseline DEA model of Table A3.1 (column 3). Data from 2001 to the latest available year have been used. The correlation between the OLS and the fixed effects estimates is 0.60 . The correlation coefficients between these estimates and those presented in Figure 4.1 are positive but not high (Table A3.4).

Table A3.3. Parametric frontier efficiency measures

\begin{tabular}{|c|c|c|}
\hline & Pooled panel model & Fixed effects model \\
\hline AUS & 0.65 & 0.64 \\
\hline AUT & 0.72 & 0.77 \\
\hline BEL & 0.63 & 0.71 \\
\hline CAN & 0.68 & 0.54 \\
\hline $\mathrm{CHE}$ & 0.59 & 0.81 \\
\hline CZE & 0.64 & 0.70 \\
\hline DEU & 0.74 & 0.97 \\
\hline DNK & 0.63 & 0.75 \\
\hline ESP & 0.56 & 0.66 \\
\hline EST & 0.67 & 0.33 \\
\hline FIN & 0.77 & 0.83 \\
\hline FRA & 0.62 & 0.80 \\
\hline GBR & 0.71 & 0.97 \\
\hline GRC & 0.62 & 0.50 \\
\hline HUN & 0.66 & 0.65 \\
\hline IRL & 0.72 & 0.69 \\
\hline ISL & 0.74 & 0.72 \\
\hline ITA & 0.76 & 1.00 \\
\hline JPN & 0.65 & 0.69 \\
\hline KOR & 0.67 & 0.99 \\
\hline LUX & 0.50 & 0.32 \\
\hline MEX & 0.71 & 0.76 \\
\hline NLD & 0.91 & 0.95 \\
\hline NOR & 0.74 & 0.72 \\
\hline NZL & 0.66 & 0.63 \\
\hline POL & 0.73 & 0.81 \\
\hline PRT & 0.63 & 0.79 \\
\hline SVK & 0.76 & 0.83 \\
\hline SVN & 0.66 & 0.59 \\
\hline SWE & 0.60 & 0.59 \\
\hline TUR & 0.65 & 0.64 \\
\hline USA & 0.56 & 0.53 \\
\hline
\end{tabular}

Note: The models include motor vehicles, kilometres of the road network and energy consumption as inputs, freight and passenger traffic as desirable outputs; injuries are modelled as undesirable outputs. All variables are in logarithm and scaled by GDP.

Source: ITF and OECD calculations. 
ECO/WKP(2013)8

Table A3.4. DEA and parametric frontier efficiency estimates are positively correlated

\begin{tabular}{ll}
\hline Parametric frontier & DEA \\
\hline OLS & 0.45 \\
Fixed effect model & 0.31 \\
\hline
\end{tabular}

Note: The models include motor vehicles, kilometres of the road network and energy consumption as inputs, freight and passenger traffic as desirable outputs; injuries are modelled as undesirable outputs. All variables are in logarithm and scaled by GDP.

Source: OECD calculations.

\section{Production function results}

Multi-output production functions were also estimated. Each output - i.e. passenger traffic, freight traffic and injuries - was regressed on all inputs - i.e. energy consumption and the length of the road network - while also controlling for all the other outputs. In addition, energy consumption and the length of the road network were regressed on each other and all outputs. The regressions also include the background factors (internal distance, roughness of topography and the length of the rail network).

Estimation of multi-output production functions relies on the assumption of non-jointness (Hall, 1973; van den Heuvel, 1986). This implies that each output is generated by a separate sub-technology, so that each of them can be represented by an individual production function. However, whether this restriction applies to the road transport sector is unknown and cannot be easily tested.

Data from 2001 onwards were used with the variables scaled by GDP and estimated in logarithms. As geographic variables do not vary over time, the random-effects model was used instead of the fixed-effects model. A full set of time fixed effects was included. To reduce endogeneity each equation was estimated separately. Standard errors are clustered by country to take into account the intra-country correlation of the error term.

Table A3.5. Production function results

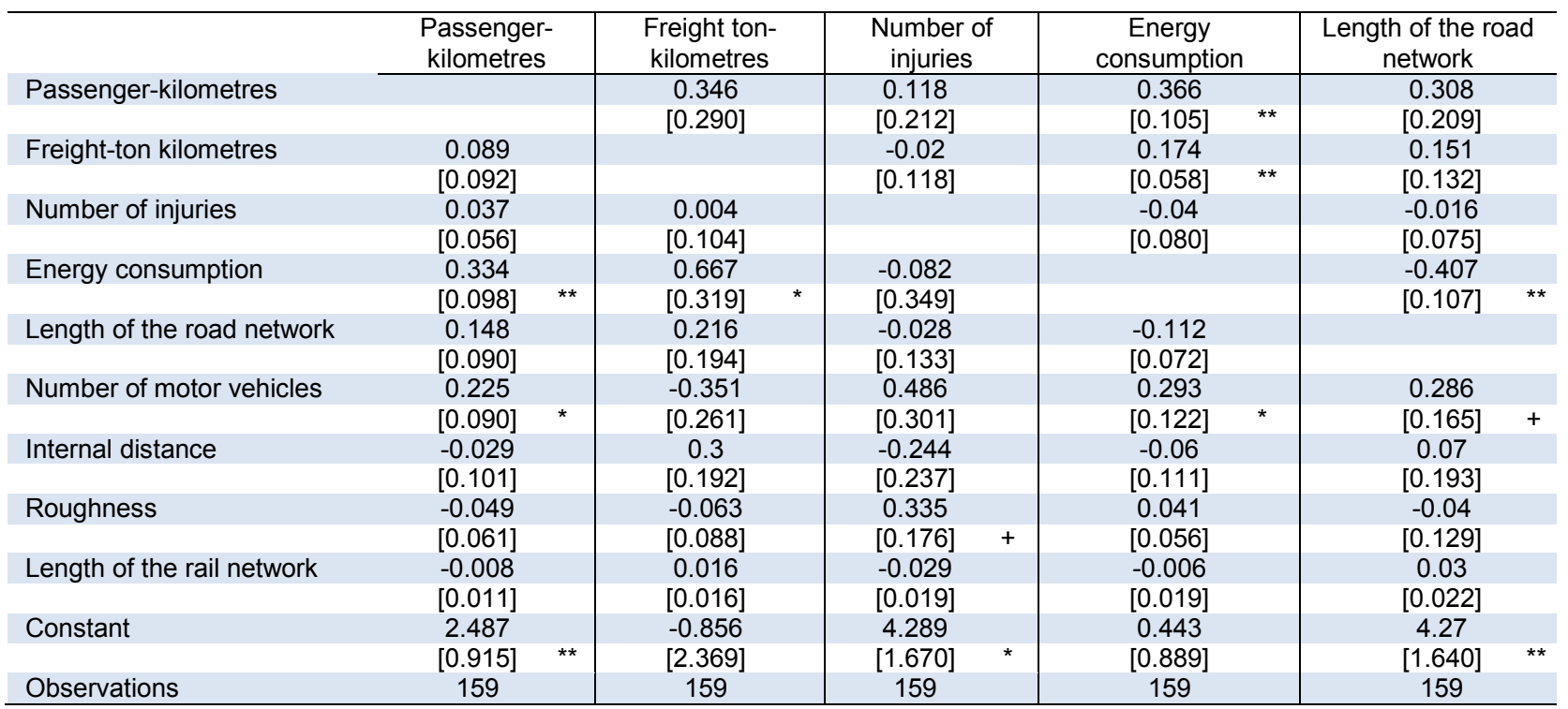

Note: Regressions are estimated by a random-effects model with standard errors clustered by country; +, ${ }^{*}$, and ${ }^{* *}$ denote statistical significance at 10,5 and $1 \%$ level. Variables are scaled by GDP and estimated in logarithms. The column heading indicates the dependent variable.

Source: OECD calculations. 


\section{BIBLIOGRAPHY}

Barnum, D. T., S. McNeil and J. Hart (2007), "Comparing the Efficiency of Public Transportation Subunits using Data Envelopment Analysis", Journal of Public Transportation, Vol. 10(2), pp. 1-16.

Bhagavath, V. (2006), Technical Efficiency Measurement by Data Envelopment Analysis: An Application in Transportation, Alliance Journal of Business Research, pp. 60-72.

Chin, A. T.H., and J.M.W. Low (2010), "Port Performance in Asia: Does Production Efficiency Imply Environmental Efficiency?", Transportation Research Part D: Transport and Environment, Vol. 15(8), pp. 483-488.

Coelli, T. and S. Perelman (1999), “A Comparison of Parametric and Non-parametric Distance Functions: With Application to European Railways", European Journal of Operational Research, Vol. 117(2), pp. 326-339.

Estache, A., B.T. de la Fe and L. Trujillo (2004), "Sources of Efficiency Gains in Port Reform: a DEA Decomposition of a Malmquist TFP Index for Mexico", Utilities Policy, Vol. 12(4), pp. 221-230.

Fukuyama, H., Y. Yoshida and S. Managi (2011), "Modal Choice between Air and Rail: A Social Efficiency Benchmarking Analysis that Considers $\mathrm{CO}_{2}$ Emissions", Environmental Economics and Policy Studies, 13(2), pp. 89-102.

Hall, R.E. (1973), "The Specification of Technology with Several Kinds of Output”, Journal of Political Economy, Vol. 81, No. 4, pp. 878-77.

Heuvel, P. van den (1986), "Nonjoint Production and the Cost Function: Some Refinements", Journal of Economics, Vol. 46, No. 3, pp. 283-297.

Krautzberger, L. and H. Wetzel (2011), "Transport and $\mathrm{CO}_{2}$ : Productivity Growth and Carbon Dioxide Emissions in the European Commercial Transport Industry", EWI Working Paper, No 11/13.

Lozano, S., and E. Gutiérrez (2011), "Slacks-Based Measure of Efficiency of Airports with Airplane Delays as Undesirable Outputs", Computers \& Operations Research, Vol. 38(1), 131-139.

McMullen, S.B. and D.-W. Noh (2007), "Accounting for Emissions in the Measurement of Transit Agency Efficiency: A Directional Distance Function Approach", Transportation Research Part D: Transport and Environment, Vol. 12(1), pp. 1-9.

O’Donnell, C.J. and T.J. Coelli (2005), “A Bayesian Approach to Imposing Curvature on Distance Functions", Journal of Econometrics, Vol. 126(2), pp. 493-523.

Oh, M., E. Shon, S. Kim and D. Park (2011), "Efficiency Analysis of Seoul's Urban Bus Agencies Considering Emissions", KSCE Journal of Civil Engineering, Vol. 15(5), pp. 899-905. 
Pathomsiri, S., A. Haghani, M. Dresner and R.J. Windle (2008), "Impact of Undesirable Outputs on the Productivity of US Airports", Transportation Research Part E: Logistics and Transportation Review, Vol. 44(2), pp. 235-259.

Weber, M.M. and W.L. Weber (2004), "Productivity and Efficiency in the Trucking Industry: Accounting for Traffic Fatalities", International Journal of Physical Distribution \& Logistics Management, Vol. 34(1), pp. 39-61.

Yu, M.-M. (2004), "Measuring Physical Efficiency of Domestic Airports in Taiwan with Undesirable Outputs and Environmental Factors", Journal of Air Transport Management, Vol. 10(5), pp. 295-303.

Yu, M.-M., and C.-K. Fan (2006), "Measuring the Cost Effectiveness of Multimode Bus Transit in the Presence of Accident Risks", Transportation Planning and Technology, Vol. 29(5), 383-407. 
ECO/WKP(2013)8

\section{WORKING PAPERS}

The full series of Economics Department Working Papers can be consulted at www.oecd.org/eco/workingpapers/

1015. The US labour market recovery following the great recession (January 2013) by Wendy Dunn

1014. Why do Russian firms use fixed-term and agency work contracts? (January 2013) by Larisa Smirnykh and Andreas Wörgötter

1013. The Equity implications of fiscal consolidation (December 2012) by Lukasz Rawdanowicz, Eckhard Wurzel and Ane Kathrine Christensen

1012. The Dutch labour market: preparing for the future

(December 2012) by Mathijs Gerritsen and Jens Høj

1011. Reforming policies for the business sector to harvest the benefits of globalisation in the Netherlands

(December 2012) by Mathijs Gerritsen and Jens Høj

1010. Health care reform and long-term care in the Netherlands (December 2012) by Erik Schut, Stéphane Sorbe and Jens Høj

1009. Enhancing the inclusiveness of the labour market in Belgium (December 2012) by Jens Høj

1008. Reducing poverty in Estonia through activation and better targeting (December 2012) by Sarah Flèche and Artur Radziwill

1007. Matching skills and jobs in Estonia (December 2012) by Lilas Demmou

1006. Debt and macroeconomic stability: An overview of the literature and some empirics (December 2012) by Douglas Sutherland and Peter Hoeller

1005. Debt and macroeconomic stability: Debt and the business cycle (December 2012) by Volker Ziemann

1004. Debt and macroeconomic stability: Case studies

(December 2012) by Rossana Merola

1003. Debt and macroeconomic stability

(December 2012) by Douglas Sutherland, Peter Hoeller, Rossana Merola and Volker Ziemann

1002. Reducing greenhouse gas emissions in a cost effective way in Switzerland.

(December 2012) by Anita Wölfl and Patrizio Sicari

1001. Strengthening innovation in the United States

(November 2012) by David Carey, Christopher Hill and Brian Kahin 
1000. Long-term growth scenarios

(January 2013) by Åsa Johansson, Yvan Guillemette, Fabrice Murtin, David Turner,

Giuseppe Nicoletti, Christine de la Maisonneuve, Philip Bagnoli, Guillaume Bousquet and

Francesca Spinelli

999. Selected aspects of household savings in Germany-evidence from micro-data

(November 2012) by Christina Kolerus, Isabell Koske and Felix Hüfner

998. Improving the tax system in Indonesia

(November 2012) by Jens Arnold

997. Unleashing business innovation in Canada

(November 2012) by Alexandra Bibbee

996. Public policy and resource allocation: evidence from firms in OECD countries

(October 2012) by Dan Andrews and Federico Cingano

995. Promoting SME development in Indonesia

(October 2012) by Annabelle Mourougane

994. Portugal: Rebalancing the economy and returning to growth through job creation and better capital allocation.

(October 2012) by Álvaro Pina and Ildeberta Abreu

993. Public debt, economic growth and nonlinear effects: Myth or reality?

(October 2012) by Balázs Égert

992. Choosing the pace of fiscal consolidation

(September 2012) by Lukasz Rawdanowicz

991. Tertiary education developing skills for innovation and long-term growth in Canada

(September 2012) by Calista Cheung, Yvan Guillemette and Shahrzad Mobasher-Fard

990. Trade and product market policies in upstream sectors and productivity in downstream sectors: firm-level evidence from China

(September 2012) by Maria Bas and Orsetta Causa

989. Intangible assets, resource allocation and growth: a framework for analysis

(September 2012) by Dan Andrews and Alain de Serres

988. Current account benchmarks for Turkey

(September 2012) by Oliver Röhn

987. Structural reforms to boost Turkey's long-term growth

(September 2012) by Rauf Gönenç, Oliver Röhn, Vincent Koen and Şeref Saygili

986. Tackling Turkey's external and domestic macroeconomic imbalances

(September 2012) by Oliver Röhn, Rauf Gönenç, Vincent Koen and Ramazan Karaşahin

985. Portugal: Solid foundations for a sustainable fiscal consolidation

(September 2012) by David Haugh and Stéphane Sorbe 